\title{
VASCO DE QUIROGA EN EL 450 ANIVERSARIO DE SU MUERTE (1565-2015)
}

\section{JOSÉ LUIS SOBERANES FERNÁNDEZ EDUARDO ALEJANDRO LÓPEZ SÁNCHEZ}


VASCO DE QUIROGA EN EL 450 ANIVERSARIO DE SU MUERTE (1565-2015) 


\title{
INSTITUTO DE INVESTIGACIONES JURÍDICAS
}

Serie EsTudios JuRÍdicos, núm. 304

\section{COORDINACIÓN EDITORIAL}

\author{
Lic. Raúl Márquez Romero
}

Secretario Técnico

Lic. Wendy Vanesa Rocha Cacho

Jefa del Departamento de Publicaciones

Cristopher Raúl Martínez Santana

Cuidado de la edición y formación en computadora

Mauricio Ortega Garduño

Elaboración de portada 


\section{VASCO DE QUIROGA EN EL 450 ANIVERSARIO DE SU MUERTE (1565-2015)}

JosÉ Luis SOBERANES FERNÁNDEZ

EDUARDO ALEJANDRO LÓPEZ SÁNCHEZ

Coordinadores
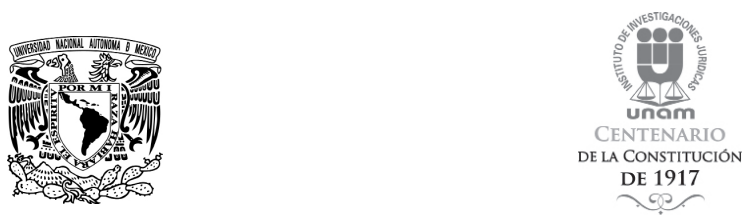

UNIVERSIDAD NACIONAL AUTÓNOMA DE MÉXICO INSTITUTO DE INVESTIGACIONES JURÍDICAS MÉXICO, 2017 
Primera edición: 7 de abril de 2017

DR (C) 2017. Universidad Nacional Autónoma de México INSTITUTO DE INVESTIGACIONES JURÍDICAS

Circuito Maestro Mario de la Cueva s/n Giudad de la Investigación en Humanidades Ciudad Universitaria, 04510 Ciudad de México

Impreso y hecho en México

ISBN 978-607-02-9031-2 


\section{GONTENIDO}

Presentación ...................... IX

Eduardo Alejandro LÓPEZ SÁNCHEZ

La mentalidad laical en Vasco de Quiroga . . . . . . . . . 1 Pablo ARGe Gargollo

La catedral perdida de don Vasco. Vasco de Quiroga, innovador en arquitectura eclesiástica . . . . . . . . . . 29 Armando Mauricio Escobar OLMEDO

Vasco de Quiroga y la repercusión social de sus puebloshospital: ayer y hoy ................ 61 Álvaro LOZANO PlatonOfF

La teología de la hospitalidad, implícita en el pensamiento y en la praxis de Vasco de Quiroga . . . . . . . . 87 Manuel GonZÁLEz CRUZ

Vasco de Quiroga y los inicios del ius commune en la provincia de Valladolid de Michoacán . . . . . . . . . . . . . Jaime HERnÁNDEZ DíAZ 
Este libro forma parte del acervo de la Biblioteca Jurídica Virtual del Instituto de Investigaciones Jurídicas de la UNAM

\section{PRESENTACIÓN}

Académicos de distintas instituciones se han reunido en un seminario permanente, desde 2011, para analizar y dar cuenta del desarrollo del constitucionalismo en México, desde una perspectiva multidisciplinaria, en el que participan la Universidad Nacional Autónoma de México, a través de la Coordinación de Humanidades, el Instituto de Investigaciones Jurídicas y la Unidad Académica de Estudios Regionales de la Coordinación de Humanidades; la Universidad Michoacana de San Nicolás de Hidalgo; El Colegio de Michoacán, A. C.; el Centro Universitario de Ciencias Sociales y Humanidades de la Universidad de Guadalajara, y la Universidad de La Ciénega del Estado de Michoacán de Ocampo de la UNAM.

Como resultado de este seminario se han llevado a cabo diversas actividades académicas, como seminarios, congresos internacionales y coloquios, a saber: septiembre de 2011, Seminario "Independencia y Constitución"; septiembre de 2012, Congreso Internacional "La Constitución de Cádiz a doscientos años; perspectiva e impacto en el occidente novohispano", y octubre de 2014, Congreso Internacional "A doscientos años de la Constitución de Apatzingán".

La figura de Vasco de Quiroga reviste especial importancia como defensor de los derechos de los pueblos indígenas de Michoacán, quien llegó en enero de 1531 a la Nueva España por mandato del rey Carlos V. El "Tata Vasco" - como lo nombraba la población indígena purépecha - creó diversas instituciones, entre las que destacan el Hospital de Tzintzuntzan y la Casa de expósitos de Santa Fe de la Laguna; asimismo, enseñó diversos 
Este libro forma parte del acervo de la Biblioteca Jurídica Virtual del Instituto de Investigaciones Jurídicas de la UNAM

oficios a los indígenas, a fin de que cada región contara con una actividad económica específica, e impulsó la actividad ganadera de la región con ganado equino, porcino y lanar.

El 10 de septiembre de 2015, siendo sede la Unidad Académica de Estudios Regionales de la Coordinación de Humanidades de la UNAM, ubicada en Jiquilpan de Juárez, Michoacán, se realizó un coloquio para conmemorar el 450 aniversario de su muerte (1565-2015).

El coloquio se dividió en tres mesas de trabajo, con un total de nueve ponencias, que por diversas circunstancias no fueron integradas en su totalidad a esta obra; sin embargo, considero importante mencionar todas.

La primera mesa de trabajo fue integrada por José Luis Soberanes Fernández, "Don Vasco de Quiroga"; Pablo Arce Gargollo, "La mentalidad laica en Vasco de Quiroga", y Armando Mauricio Escobar Olmedo, "La catedral perdida de don Vasco. Vasco de Quiroga, innovador en arquitectura eclesiástica".

En la segunda mesa participaron Francisco Miranda, "Elementos para una pedagogía quiroguiana"; Álvaro Lozano Platonoff, "Vasco de Quiroga y la repercusión social de sus puebloshospital: ayer y hoy", y Manuel González Cruz, "La teología de la hospitalidad, implícita en el pensamiento y en la praxis de Vasco de Quiroga".

La tercera y última mesa se conformó por Carlos Herrejón Peredo, "Las fuentes de la información en derecho"; Carlos Francisco Martínez Moreno, "Reflexiones filosófico-políticas en torno al Tratado de Debellandis Indis", y Jaime Hernández Díaz, "Vasco de Quiroga y los inicios del ius commune en la provincia de Valladolid de Morelia".

Por último, es imprescindible agradecer a todos los ponentes, así como de manera especial a todas y cada una de las instituciones participantes, por el esfuerzo e invaluable colaboración para la realización del "Coloquio Vasco de Quiroga en el 450 aniversario de su muerte 1565-2015", que sin duda ha marcado un pre- 
Este libro forma parte del acervo de la Biblioteca Jurídica Virtual del Instituto de Investigaciones Jurídicas de la UNAM

cedente en la región de La Ciénega, toda vez que no hay registro de otra colaboración similar entre las instituciones convocantes y que tiene como fruto la presente publicación.

Eduardo Alejandro LÓPEz SÁNCHEZ

Unidad Académica de Estudios Regionales de la Coordinación de Humanidades, UNAM 
Este libro forma parte del acervo de la Biblioteca Jurídica Virtual del Instituto de Investigaciones Jurídicas de la UNAM

\title{
LA MENTALIDAD LAICAL EN VASGO DE QUIROGA*
}

\author{
Pablo ARCe Gargollo
}

\begin{abstract}
Sumario: I. Concepto de laico. II. Mentalidad laical en el siglo XVI. III. La Iglesia pretridentina en la España de Vasco de Quiroga. IV. Eclesiásticos en la monarquía de los Austrias. V. Familia de Vasco de Quiroga. VI. Caballero de Malta. VII. Mentalidad laical de un caballero reformista. VIII. Reflejos de la mentalidad laical de Vasco de Quiroga. IX. Conclusiones. X. Bibliografia.
\end{abstract}

Decir que Vasco de Quiroga era un laico antes de recibir el sacramento del orden sacerdotal y episcopal es una obviedad.

Sostener que mantuvo siempre, durante toda su vida - incluso siendo obispo- - una mentalidad laical y secular nos permitirá entender a cabalidad la persona y actuación de Vasco de Quiroga.

Esta afirmación es aún más sorprendente si se tiene en cuenta el ambiente preponderantemente clerical y religioso en el que desarrolló su actividad.

Será interesante, por tanto, entender el concepto de laico en el siglo XVI y señalar algunos rasgos de la vida de la Iglesia en España y América anterior al Concilio de Trento (1545-1563), con el regalismo y la influencia de los eclesiásticos de la Corte. Éste es el ambiente que rodeaba a la familia de los Quiroga.

Estas circunstancias nos dejarán ver el clericalismo imperante en la época en que vivió Vasco de Quiroga, en donde la parti-

* Presentación en el Coloquio "Vasco de Quiroga en el 450 aniversario de su muerte 1565-2015", Unidad Académica de Estudios Regionales, Coordinación de Humanidades, UNAM, Jiquilpan de Juárez, Michoacán, 10 de septiembre de 2015 . 
Este libro forma parte del acervo de la Biblioteca Jurídica Virtual del Instituto de Investigaciones Jurídicas de la UNAM

cipación activa del laicado en el ámbito propio de la Iglesia era reducido, y en donde los laicos asumían ciertas actitudes sumisas a lo religioso o se planteaban acceder al mundo clerical para poder sobresalir. Es por todo esto que destaca notablemente la mentalidad laical que a lo largo de toda su vida mantuvo Vasco de Quiroga. Reseñaré algunos hechos en su vida que lo muestran con claridad.

\section{Goncepto DE LAICO}

Una imprescindible exigencia de precisión conceptual obliga, en primer lugar, a definir el concepto de laico, y, en segundo lugar, señalar cómo era entendido en tiempos de la vida de Vasco de Quiroga.

Desde los primeros siglos del cristianismo hasta la Edad Media, el nombre de "laico" se usó para designar a los fieles cristianos inmersos en las realidades profanas, lo que los distinguía tanto de los monjes como de los clérigos. ${ }^{1}$

A partir de la Edad Media se da un paulatino desdoblamiento del concepto "laico" que lo deforma un poco. En concreto:

a) Se va perdiendo gradualmente el sentido de participación activa del laicado en el ámbito propio de la Iglesia — tan vivo en los primeros siglos - , hasta el punto de que la misión de la Iglesia llega a identificarse de modo casi exclusivo con el ministerio de los clérigos.

b) A su vez, se piensa que la plenitud de la vida cristiana corresponde solamente a clérigos y religiosos, mientras que los laicos han de contentarse con vivir las virtudes comunes en el ejercicio de sus tareas profanas, consideradas por muchos como un obstáculo para la verdadera santidad.

1 Portillo, Álvaro del, voz "Laicos. Teología", Gran enciclopedia Rialp, Madrid, 1991. 
Este libro forma parte del acervo de la Biblioteca Jurídica Virtual del Instituto de Investigaciones Jurídicas de la UNAM

En este contexto ideológico e histórico, la palabra "laico" en tiempos de Vasco de Quiroga designará a un miembro meramente pasivo de la Iglesia — no ordenado ni religioso — sin ningún elemento positivo que especifique su condición, puesto que la inserción en el orden temporal se ve sólo como algo negativo, como reflejo de una falta de vocación más alta.

\section{MentalidAD LAICAL EN EL SIGLO XVI}

Entender el concepto de "mentalidad laical" no es fácil, y menos aún la connotación que pudo tener en el siglo XVI.

Álvaro Silva — "el historiador español que mejor conoce a Tomás Moro" —2 ha señalado que el concepto "mentalidad laical" es "una expresión moderna que no hubiera tenido mucho sentido en el siglo XVI, cuando todavía la religión lo empapaba todo". ${ }^{3}$ Álvaro Silva ilustra su afirmación diciendo que "Moro, por ejemplo, era un laico, es decir, no era clérigo y hace una crítica fuerte a los monjes (Carta a un monje) pero su vida cristiana sigue más o menos el ideal o modelo monástico". Concluye Silva con una sugerente aseveración: "quizá Lutero tuvo mucha mayor «mentalidad laical» aunque sólo fuera por su ímpetu contra el sacerdocio de la Iglesia Romana”.

Parece cierto que muchos de los laicos que buscaban la perfección cristiana en la Edad Media y en el Renacimiento - $\mathrm{y}$ después hasta el siglo XX - se vieron en la necesidad de seguir algunas pautas monásticas o religiosas, pues prevalecía la idea

2 Esto lo afirma Ricardo García Cárcel, catedrático de Historia moderna en la Universidad Autónoma de Barcelona, en Moro, Tomás, Carta a un monje, Salamanca, Ediciones Universidad de Salamanca, 2009, 145 pp.

3 Conversación con Álvaro Silva desde Boston, 27 de febrero de 2015. Álvaro Silva es un reconocido estudioso de Tomás Moro. Sostenemos algunas conversaciones al año sobre conceptos y coincidencias que se dan entre Quiroga y quien fue gran canciller de Enrique VIII. Es muy recomendable su libro Silva, Álvaro, Tomás Moro: un hombre para todas las horas, Madrid, Marcial Pons, 2007. 
Este libro forma parte del acervo de la Biblioteca Jurídica Virtual del Instituto de Investigaciones Jurídicas de la UNAM

de que la plenitud cristiana correspondía solamente a clérigos y religiosos.

Los laicos que no se conformaban con vivir las virtudes comunes en el ejercicio de sus tareas profanas, consideradas por muchos como un obstáculo para la verdadera santidad, tomaban los ideales religiosos y los adoptaban en su vida diaria, buscando seria y decisivamente la santidad. Éste es el caso de Moro y de otros más; basta considerar que en el santoral de la época no hay santos laicos.

Sin embargo, me parece que el caso de Vasco de Quiroga es diferente y, por eso, sorprendente. A él no se le conocen rasgos monásticos o religiosos ni en su actuación ni en su vida de piedad. Su modo de actuar, en toda circunstancia, tiene la marca de una auténtica mentalidad laical.

Hay dos elementos que le dan a Vasco de Quiroga su fisonomía laical: 1) el haber sido caballero de una orden hospitalaria, y 2) su humanismo renacentista con inspiración erasmista.

\section{LA IGLESIA PRETRIDENTINA EN LA ESPAÑA DE VASGO DE QUIROGA}

Una rápida valoración de la vida de la Iglesia en la España en que vivió Vasco de Quiroga antes de su arribo al Nuevo Mundo puede ser de utilidad, como contraste, para entender unos rasgos importantes en la vida del licenciado Quiroga.

Aunque es verdad que las reformas animadas por los Reyes Católicos lograron revitalizar la vida de la Iglesia en España, en especial a partir de la renovación de algunas instituciones de los religiosos, y contuvieron la difusión del protestantismo, los frutos fueron lentos y titubeantes. De manera somera vale la pena señalar algunos rasgos muy generales, con el riesgo de faltar a la verdad, de lo que era la vida de los laicos y de los eclesiásticos en aquella época.

La ignorancia religiosa entre los fieles laicos estaba sumamente extendida, y el primer concilio en España que tomó nota del 
Este libro forma parte del acervo de la Biblioteca Jurídica Virtual del Instituto de Investigaciones Jurídicas de la UNAM

problema - el celebrado en Sevilla en 1512 - constató que numerosos fieles desconocían las oraciones básicas. ${ }^{4}$

Muchos eclesiásticos de mediados del siglo XVI afirmaban que no hacía falta marcharse a América a evangelizar, ya que también en España había "Indias", entendiendo por tales aquellas zonas en las que predominaba la ignorancia religiosa y se seguían practicando ritos precristianos. ${ }^{5}$

\section{ECLESIÁSTICOS EN LA MONARQUÍA DE LOS AUSTRIAS}

El nivel moral e intelectual de buena parte del estamento eclesiástico no era ejemplar y se dieron casos que ocasionaron un auténtico escándalo. ${ }^{6}$ Así, un gran número de candidatos al presbiterado buscaban las instituciones eclesiásticas como medio seguro de subsistencia; eran pocos los sacerdotes que sabían predicar; era deficiente su formación específica, y algunos obispos se contentaban con que los sacerdotes supieran leer, escribir, pronunciar el latín y conocer el modo de administrar los sacramentos; se encontraban extendidos el concubinato, las pendencias y la corrupción; igualmente, muchos canónigos no eran sacerdotes, pero percibían las rentas de sus prebendas sin cumplir con sus obligaciones; vivían aseglarados; vestían trajes lujosos; frecuentaban actos sociales frívolos y no se ocupaban de la cura de almas; el absentismo clerical campaba por doquier, etcétera.

La jerarquía eclesiástica en el siglo XVI español ha sido perfectamente estudiada. ${ }^{7}$ Estamos bien informados acerca de su

4 González, Francisco Antonio (ed.), Colección de cánones de la Iglesia española: concilios del siglo XV en adelante, Madrid, 1855, t. V.

5 Testimonios relativos a Cataluña, Asturias, Andalucía o Galicia dan buena prueba de ello. Cfr. Kamen, H., The Phoenix and the Flame. Catalonia and the Counter Reformation, New Haven, Yale U. P., 1993.

6 Núñez Roldán, F., El pecado nefando del obispo de Salamina. Un hombre sin concierto en la Corte de Felipe II, Sevilla, Universidad, 2002.

7 Barrio Gozalo, Maximiliano, "La jerarquía eclesiástica en la España moderna. Sociología de una élite de poder (1556-1834)", Cuadernos de Historia 
Este libro forma parte del acervo de la Biblioteca Jurídica Virtual del Instituto de Investigaciones Jurídicas de la UNAM

procedencia social, la cual es marcadamente nobiliaria, sobre todo hidalga; su preparación intelectual, por haber cursado alguna carrera universitaria, constituyó en la práctica un requisito fundamental para acceder al episcopado, así como sus cargos detentados con anterioridad, en especial el haber sido del clero capitular, que se estableció como la gran cantera de futuros obispos.

Estudios recientes de la actuación de los eclesiásticos en los niveles más altos de la monarquía española de los siglos XVI y XVII nos permiten también conocer el ambiente en el que se debió mover Vasco de Quiroga y - por contraste - su postura laical. ${ }^{8}$

La presencia de altos dignatarios eclesiásticos en la Corte, como los arzobispos de Toledo, inquisidores generales, diversos obispos y los confesores reales, hacen pensar en un influjo notable de clérigos en la vida social y política, que enseña poco el papel preponderante que deben tener los laicos en la vida de la Iglesia. ${ }^{9}$

\section{FAMilia de VASGO DE QUiROGa}

La familia de Vasco de Quiroga es de origen noble. Ellos habían venido a menos desde la posición de ricoshombres en el siglo XIII a la de hidalgos de mediana fortuna en el siglo XV. La familia de Vasco de Quiroga partía de una destacada posición en torno de la Orden de San Juan de Jerusalén, en la que varios familiares, in-

Moderna, núm. 25, 2000; id., "La Iglesia y los eclesiásticos en la España del seiscientos. Beneficios y beneficiados", en Alcalá Zamora, J. y Belenguer Cebria, E. (coords.), Calderón de la Barca y la España del Barroco, Madrid, Centro de Estudios Políticos y Constitucionales-Sociedad Estatal Nuevo Milenio, 2001, vol. 1; id., El Real Patronato y los obispos españoles del antiguo régimen (1556-1834), Madrid, Centro de Estudios Políticos y Constitucionales, 2004.

8 Morgado García, Arturo, "El clero en la España de los siglos XVI y XVII. Estado de la cuestión y últimas tendencias", Manuscrits, Cádiz, núm. 25, 2007, pp. 75-100.

9 Álvarez-Ossorio, A., "La Corte: un espacio abierto para la historia social", en Castillo A., Santiago (coord.), La historia social en España: actualidad y perspectivas, Madrid, Siglo XXI, 1991. 
Este libro forma parte del acervo de la Biblioteca Jurídica Virtual del Instituto de Investigaciones Jurídicas de la UNAM

cluido su padre, habían ostentado cargos importantes a lo largo de los siglos. ${ }^{10}$

Madrigal - lugar de nacimiento de Vasco de Quiroga-y Arévalo - sitio donde radicaban los orígenes maternos - fueron los puntos de contacto con la corte itinerante de Juan II y la reina Isabel de Portugal, madre de la Reina Católica. En ese ambiente, Vasco de Quiroga tuvo su primera educación y las amistades que determinaron su vida de forma decisiva.

En el ambiente familiar de Vasco de Quiroga aparecen con frecuencia eclesiásticos. Así, tenemos que un tío abuelo, fray Gonzalo de Quiroga, fue prior de la Orden de San Juan; un sobrino, Gaspar de Quiroga — hijo de su hermano Álvaro-, se desempeñó como visitador del Reino de Nápoles, inquisidor, obispo de Cuenca, arzobispo de Toledo y cardenal; su hermana Constanza y cinco sobrinas profesaron como religiosas; ${ }^{11}$ sobrinos de su sobrino Gaspar fueron eclesiásticos, como Pedro, Juan, Gaspar y Tomás Quiroga; otros sobrinos fungieron como eclesiásticos, entre ellos tenemos a Álvaro y Francisco de Monsalve, León de Alderete, Francisco Morejón y fray Tomás de Guzmán, quien ocupó el cargo de provincial en la Orden de Santo Domingo. ${ }^{12}$ Como se puede observar, en la familia Quiroga hay un buen número de vocaciones a la vida sacerdotal o religiosa.

10 Delgado Pérez, María Mercedes, "Vasco de Quiroga y la génesis de un códice fronterizo", IX Estudios de Frontera, Universidad de Sevilla, 2013.

11 Su sobrino Juan, hijo de su hermano Álvaro, se casó con doña Teresa de Villarcel y tuvieron cuatro hijas: Elena, María, Elvira y Ana; dos de ellas fueron monjas en Santa María de Gracia. Catalina de Aldrete, hija de su sobrina María y Francisco de Aldrete, se desempeñó como monja en las Huelgas de Valladolid. Su sobrina Agustina, que se casó con Alonso de Guzmán y Zuazo, tuvo por hijos a fray Tomás de Guzmán (provincial de la Orden de Santo Domingo), Tomás de Quiroga (rector del Colegio de San Bartolomé de Salamanca), Álvaro de Quiroga (caballerizo del rey y caballero de Santiago), y dos hijas que se hicieron monjas.

12 Pizarro Llorente, Henar, "Los miembros del cabildo de la Catedral de Toledo durante el arzobispado de Gaspar de Quiroga (1577-1594)", Hispania Sacra, LXII, 126, julio-diciembre de 2010, pp. 563-619. También véase AHN, Consejos 5310, cuarta pieza, f. 14s y f. 84s. 
Este libro forma parte del acervo de la Biblioteca Jurídica Virtual del Instituto de Investigaciones Jurídicas de la UNAM

Desde niño Vasco de Quiroga tuvo contacto con muchos eclesiásticos, amigos de la familia. Fue decisiva su relación con Juan Pardo de Tavera, quien en 1524 ocupó el cargo de arzobispo de Santiago de Compostela y se le nombró como cardenal en 1531, y a través de él, con fray Diego de Deza, el cual se desempeñó como arzobispo de Sevilla. Pardo de Tavera ayudó a Vasco de Quiroga a entrar a la Universidad de Salamanca.

Otra importante relación en la vida de Vasco de Quiroga fue la que mantuvo con el jerónimo Hernando de Talavera, a quien prestó servicios mientras ejerció de obispo de Ávila. Así pues, Hernando de Talavera fungió como confesor y consejero de Isabel la Católica, y, posteriormente, en 1493 lo nombraron arzobispo de Granada, en donde le apodaron el alfaquí santo. Con Hernando de Talavera compartirá Vasco de Quiroga algunos conceptos fundamentales: la evangelización no violenta y progresiva de los infieles, el respeto a la dignidad de la persona y la convivencia entre personas de diversa religión. En estos años apareció un nuevo mentor, Juan Bernal Díaz de Luco, futuro obispo de Calahorra y perteneciente también al círculo de Pardo Tavera, con quien Vasco de Quiroga coincidió en varios conceptos, los cuales aplicará en el Nuevo Mundo. ${ }^{13}$

Cuando laboraba para la Corte, su relación con eclesiásticos era una constante, para muestra de ello basta señalar sus contactos con García de Loaysa y Mendoza, quien fue presidente

13 Juan Bernal Díaz de Luco es señalado como uno de los reformadores hispanos de la Iglesia en la primera mitad del siglo XVI; además, es autor de una prolífica producción, en donde destaca Aviso de curas, la cual data de 1531. Juan Bernal Díaz de Luco destacó como miembro del Consejo de Indias y participó en el Concilio de Trento; asimismo, fue gran amigo de Vasco de Quiroga y es el destinatario de su escrito de 1535, que se conoce como Información en derecho, y del tratado perdido De debellandis indis. En 1988, René Acuña publicó una obra anónima bajo este título y lo atribuyó, sin pruebas suficientes, a Vasco de Quiroga. La aparición del texto Suma [sobre] como serán compellidos los indios que quedan por ayanar y subiectar parece ser un documento signado por Quiroga y es el compendio del tratado perdido De debellandis indis. Este texto no corresponde en absoluto con lo publicado por Acuña, y sí, en cambio, con el Parecer sobre este tratado, que fue remitido hacia 1551 por fray Miguel de Arcos al arzobispo Alonso de Montufar. 
Este libro forma parte del acervo de la Biblioteca Jurídica Virtual del Instituto de Investigaciones Jurídicas de la UNAM

del Consejo de Indias (1524), obispo de Osma (1525) y cardenal (1530), así como el trato que mantuvo con Mercurino Arborio di Gattinara, gran canciller de Carlos V elevado a cardenal en 1529.

\section{Caballero de Malta}

En ese ambiente de eclesiásticos, Vasco de Quiroga decidió ir a la universidad, muy probablemente a la de Salamanca. No hay noticia alguna de que él tuviera intenciones de ser sacerdote; en cambio, sí tenemos certeza de que mientras hacía sus estudios universitarios cumplió con los requisitos para ser nombrado caballero de la Soberana Orden Militar y Hospitalaria de San Juan de Jerusalén, que luego fue de Rodas y actualmente es de Malta. ${ }^{14}$

Hoy podemos afirmar que Vasco de Quiroga fue investido como caballero de Malta en 1511, cuando sólo contaba con veintitrés años. ${ }^{15}$

14 Jerusalén, ciudad santa por excelencia que es venerada por las tres religiones monoteístas: los "judíos" la tienen como sede capital desde la época del rey David, donde está el Templo construido por Salomón; los "musulmanes" aseguran que en ella ascendió a los cielos Mahoma, y los "cristianos", entre otros muchos motivos, por los lugares en los que estuvo Jesucristo, de manera especial los correspondientes a su pasión, muerte y resurrección. Esta ciudad fue conquistada por los musulmanes en el año de 637, lo que ocasionó las distintas Cruzadas buscando su recuperación. Lugar de muchas peregrinaciones, en 1048 Gerardo, caballero italiano de Amalfi, erigió una iglesia y un hospital, constituyendo una cofradía dedicada a alimentar, sanar y cuidar a peregrinos. La cofradía debió trasladarse a la Isla de Rodas perseguidos por los musulmanes, en donde permanecieron hasta 1530. Nuevas persecuciones los llevaron hasta la Isla de Malta, dada en concesión por el emperador Carlos V.

15 Se puede señalar a 1488 como el año en que nació Vasco de Quiroga. Los investigadores, al no disponer de un dato cierto, diferimos en datar su nacimiento. Hay diversas posturas: 1470 (Juan Joseph Moreno y Gil González Dávila), 1477 (Cristóbal Cabrera y Warren), 1479 (Félix F. Martínez), 1485 (Francisco Martín Hernández), 1488 (Pablo Arce Gargollo). Sostengo que nació en 1488 gracias a las siguientes fuentes: su fecha de investidura como caballero de la Orden de San Juan; dos breves pontificios, y una declaración de Vasco ante la Real Audiencia de México. La primera fuente señala que en 1511 Vasco fue investido como caballero de Malta. De haber nacido entre 1470 y 1479, él pudo ser nom- 
Este libro forma parte del acervo de la Biblioteca Jurídica Virtual del Instituto de Investigaciones Jurídicas de la UNAM

En concreto, el 10 de marzo de 1511 se le asignó en Rodas un comisario, el cual examinó "los escritos y sus juramentos, y el informe". Meses después, el 4 de junio de 1511, también en Rodas, se le reconoció la antianitas, por lo que a Vasco de Quiroga se le recibió como caballero de la Orden de San Juan. ${ }^{16}$ Es probable, por tanto, que Vasco de Quiroga haya pasado una temporada viviendo en Rodas, al menos un tiempo que corre desde el previo a su examen hasta la fecha de su investidura como caballero. ${ }^{17}$

brado caballero entre los 34 y 43 años, lo que parece poco probable. En cambio, si su nacimiento fue en 1488, él recibió la orden de caballero a los 23 años, lo cual es más convincente, considerando que desde joven, por influencia familiar, quiso serlo. También existen dos documentos pontificios que ofrecen algunas pistas: el breve pontificio Exponi nobis, del 12 de mayo de 1549, por el que se dispensa a Vasco de hacer la visita ad limina apostolorum, en virtud de las siguientes circunstancias: la distancia, los peligros del viaje y la edad del solicitante (sesenta años). Si atendemos a este breve y restamos sesenta años a 1549, entonces Vasco de Quiroga debió nacer en 1489. Hay que tener en cuenta, sin embargo, que la petición debió hacerla Vasco con suficiente antelación, atendiendo a las dificultades de comunicación de la época. En este sentido, él debió hacer la solicitud estando ya en España, es decir, a finales de 1547, pues partió de Veracruz el 23 de mayo de 1547, o al inicio de 1548, lo que supone 1488 como el año de su nacimiento. No obstante, existe una dificultad que debe mencionarse, ya que el breve de 1549 hace referencia a un anterior, que no se encuentra, de fecha 7 de enero de 1538, en el que se le impone la obligación de hacer la visita cada seis años en vez de cada tres debido a los mismos motivos. Si atendemos a este primer breve de 1538, y le restamos sesenta años, Vasco debió nacer en 1478. Otra línea de investigación se puede apoyar en una declaración testimonial presentada por Vasco ante la Real Audiencia de México, del 9 de agosto de 1555, en la que declara "que es de edad de más de sesenta años". El rango de su edad, por tanto, puede ir de los 61 a los 69 años, lo cual permite inferir que nació entre los años de 1486 al 1495.

16 Los datos fueron confirmados por la doctora Valeria Maria Leonardi, responsable del Archivi e Biblioteca Magistrali del S. M. O. di Malta, Roma, en una comunicación que mantuve con ella el 4 de marzo de 2014. El registro de Vasco de Quiroga está en la National Library of Malta-La Valletta, en AOM 81, f. 159 y f. 172v. Valeria Maria Leonardi me aseguró que no hay registro de un periodo de permanencia de Vasco en Rodas, y respecto a la pregunta sobre la antianitas, ella contestó lo siguiente: "L'aver acquisito anzianità significa che da una data precedente alla bolla di ammissione si calcola l'anzianità appunto nell'Ordine".

17 "Todos los Caballeros estaban obligados a residir en Malta durante un lustro" sostiene Rafael Pérez Peña en su tesis doctoral, intitulada "La Soberana 
Este libro forma parte del acervo de la Biblioteca Jurídica Virtual del Instituto de Investigaciones Jurídicas de la UNAM

De acuerdo con la estructura de la Orden en el siglo XVI, Vasco debió ser miembro del primero de los estamentos, que estaba constituido por caballeros mayores de dieciséis años, de sangre ilustre y limpio nacimiento. ${ }^{18}$ A este primer grado pertenecían siempre seglares.

Lo más probable es que Vasco de Quiroga fue nombrado "Caballero de Justicia", correspondiente a los que tienen las principales dignidades. ${ }^{19}$ En la época se otorgaba también el título de "Caballero de Gracia", el cual se daba a las personas que se les pedían algunos servicios concretos a favor de preservar la religión católica.

En una solemne ceremonia, los que eran nombrados caballeros prometían huir de guerras injustas; proteger a los huérfanos, pobres y viudas, y aliviar a los pobres enfermos. Ellos debían ser hombres ejemplares, caritativos y cuidadosos de vivir la virtud de la castidad. La cruz de ocho puntas, que podían usar en sus blasones, significaba las ocho bienaventuranzas que les debían llevar a lo siguiente: mantener un gozo espiritual; vivir sin malicia; llorar los pecados; sufrir las injurias; amar la justicia; ser misericordioso; ser puro de corazón y sincero, y llevar con paciencia la persecución.

Vasco de Quiroga nunca ocultó su pertenencia a la Orden hospitalaria, pero tampoco hizo ostentación ni pregonó su calidad de caballero. En su escudo de armas, y luego en el episcopal, puede observarse - como lo ha señalado Armando Escobaruna cruz octógona, es decir, con ocho puntas, la cual está acolada o puesta por detrás, que es utilizada únicamente por quienes pertenecen a la Orden de Malta. En el escudo de Vasco sobresalen sólo dos puntas de la cruz blanca o de plata por la parte central

Orden de Malta a través de diez siglos de historia”, Universidad de Málaga, 2009.

18 Brockman, Eric, The Two Sieges of Rhodes: The Knights of St. Fohn at War, 1480-1522, Nueva York, Barnes \& Noble, 1995.

19 En comunicación con la citada doctora Valeria Maria Leonardi, al preguntarle sobre qué tipo de caballero pudo ser Vasco de Quiroga, ella nos contestó lo siguiente: "Data l'epoca, molto probabilmente un Milite di Giustizia". 
Este libro forma parte del acervo de la Biblioteca Jurídica Virtual del Instituto de Investigaciones Jurídicas de la UNAM

de cada lado del escudo, que suele ser el modo de representarla en los demás escudos de estos caballeros. ${ }^{20}$

\section{MENTALIDAD LAICAL DE UN CABALLERO REFORMISTA}

Que el licenciado Quiroga tuviera el título de caballero de Malta no es un asunto menor. A lo largo de los siglos, los caballeros de Malta han defendido que son seglares y no religiosos. ${ }^{21}$

Asimismo, que Quiroga fuera un caballero de Malta explica muy bien, a nuestro parecer, su tenor de vida y toda su actuación. Vasco de Quiroga, primero como seglar y más tarde como obispo, tuvo una mentalidad laical. ${ }^{22}$

Ser en su época un caballero de Malta le proporcionó a Vasco de Quiroga un modo de pensar y actuar diverso, por muchos motivos, al comportamiento propio del estado religioso e, incluso, al que solían tener los eclesiásticos de la época. El ostentar el título de caballero de Malta representa su singularidad de ser uno de los quizá pocos laicos de su tiempo que entendieron a cabalidad su puesto dentro de la Iglesia católica. Los efectos de su pertenencia a la Orden hospitalaria se pueden observar en su afán por ejercer con perfección su trabajo profesional y, con ocasión de su trabajo, con base en su prestigio profesional, ayudar a los demás. Vasco podrá mantener consistentemente esa manera de actuar con un sello muy laical, gracias a su preocupación por

20 Así lo prueba el trabajo de Escobar Olmedo, Armando Mauricio, Los escudos de don Vasco de Quiroga, Morelia, 1999.

21 Antúnez Aldunate, Jaime, "900 años en la mirada de hoy", conferencia en la celebración de los 900 años de la Soberana Orden de Malta, Pontificia Universidad Católica de Chile, 7 de octubre de 2013.

22 No está de más decir que el concepto de laico no tiene nada que ver con el de "laicismo", que hace referencia a la actitud de indiferentismo oficial o enfático ante el fenómeno religioso, y que trata de prescindir de todo criterio obediente a una religión positiva, especialmente en los campos de las instituciones políticas y de la enseñanza. Un interesante trabajo sobre el particular puede verse en Ollero, Andrés, España: ¿un Estado laico? La libertad religiosa en perspectiva constitucional, Navarra, Thomson-Civitas, 2005. 
Este libro forma parte del acervo de la Biblioteca Jurídica Virtual del Instituto de Investigaciones Jurídicas de la UNAM

conocer a fondo la doctrina católica, lo que le evita deformar la vida cristiana y mantener el hábito arraigado de practicar una piedad, que le lleva a tratar con Dios en medio de sus inquietudes y dificultades, sin descuidar sus ocupaciones ordinarias.

El segundo elemento que le proporciona a Vasco de Quiroga su mentalidad laical es el estar imbuido de las corrientes reformistas dentro de la Iglesia.

Vasco es un humanista ${ }^{23}$ que recibió una notable influencia del ambiente universitario ${ }^{24}$ y de la Corte. ${ }^{25}$ Influyó también en Vasco, sin duda, la visión reformista de Juan de Gerson, gran canciller de la Soborna, el cual fue el primero que sostuvo el derecho natural de cada persona a la libertad, y a quien Quiroga cita con frecuencia como apoyo indispensable de su pensamiento. ${ }^{26}$

De igual forma, Erasmo de Rotterdam tuvo impacto en Vasco de Quiroga, así como en muchos ambientes de la Iglesia en Europa. El humanista neerlandés deseaba una cristiandad que sin desprenderse de los tesoros intelectuales anteriores, tanto profanos como sagrados, apareciera reformada y renovada, abandonando

23 Vasco de Quiroga debió conocer, al menos por sus escritos y su influjo intelectual, a quienes mantuvieron su condición laical o que siendo sacerdotes no eran religiosos: Luis Vives (1492-1540), Antonio de Guevara (1480-1545), Alfonso de Valdés (1490-1532), Guillaume Budé (1468-1540), Tomás Moro (1478-1535) y Erasmo (1467-1536). Merece especial atención el caso de Francisco Cervantes de Salazar (1514-1575) por la semejanza de su vida con la de Quiroga.

24 Su formación filosófica y teológica incluyó, seguramente, a los de la Escuela Dominicana, como Juan Capreolo (1380-1444), Pedro Crockaert (14701514), Diego de Deza (1443-1523), Francisco Silvestre de Ferrara (el Ferrariense) (1474-1526), Tomás de Vio Cayetano (1469-1534), y los llamados “maestros nominalistas españoles en París".

25 Vasco de Quiroga trabajó en la Corte de Carlos V, por lo que puede conjeturarse que en él influyeron pensadores que gravitaban en el peripatético gobierno, como Adriano de Utrech, Guillermo de Croy, Mercurino Gattinara (1465-1530), Jean Sauvage, Francisco de los Cobos, Antonio de Guevara (14801545) y los hermanos Valdés.

26 En Información en derecho (cap. III), Vasco de Quiroga cita con frecuencia la obra de Gerson intitulada Tractatus de potestate et de origine juris et legum, publicada en Opera Omnia, Antwerpiae, 1706, vol. III. Juan de Gerson fue un gran personaje nominalista de la filosofía moderna. 
Este libro forma parte del acervo de la Biblioteca Jurídica Virtual del Instituto de Investigaciones Jurídicas de la UNAM

todo aquello que se había mostrado como perjudicial a la trasmisión del luminoso mensaje de Cristo.

Se entiende así el afán y la ilusión de Vasco de Quiroga de aprovechar el Nuevo Mundo, no contaminado por malos eclesiásticos, para volver a la Iglesia primitiva, aquella en donde la participación activa del laicado en el ámbito propio de la Iglesia - tan vivo en los primeros siglos - pudiera ser de nuevo una realidad actuante. ${ }^{27}$ Botón de muestra son los diversos modos en que el licenciado Quiroga se refiere a la Iglesia en un escrito de 1535: "muy grande Iglesia"; "nuestra común Iglesia"; "renaciente Iglesia de este Nuevo Mundo"; "Iglesia católica y apostólica"; "una muy grande y muy reformada Iglesia"; "esta nueva Iglesia de estas partes"; "nueva y naciente Iglesia de este Nuevo Mundo". ${ }^{28}$

Un viejo refrán español del siglo XVI que se repetía cuando el erasmismo iba permeando el mundo intelectual humanista afirmaba: "Quien habla mal de Erasmo, o es cura o es asno". Quizá esto refleja de algún modo que el afán de reformas en la Iglesia era más afín al mundo de los laicos que al de los eclesiásticos. ${ }^{29}$

Vasco de Quiroga asimila las ideas reformistas y las aplica. Esto nos permite entender correctamente su actuación a lo largo de su vida, tanto en su papel de laico siendo funcionario real, juez, oidor y máxima autoridad en la Nueva España como en los pocos meses de ejercicio sacerdotal y los años en que tuvo la plenitud del sacerdocio en su ministerio episcopal.

27 Zumárraga deja sentado un aspecto de Vasco en este sentido: "el electo Obispo de Mechoacán, con mucho estudio y cuidado, ha hecho un tratado en el cual se resume que no se puede ni debe hacer dicho bautismo, sino como se hacía en la primitiva iglesia". Cfr. "Carta de fray Juan de Zumárraga al Consejo de Indias, México, 8 de febrero de 1537”, en García Icazbalceta, Joaquín, Don fray Juan de Zumárraga, primer obispo y arzobispo de México, México, Porrúa, 1947, t. 4, doc. 12, p. 239.

28 Herrejón, Carlos, Información en derecho del licenciado Quiroga sobre algunas provisiones del Real Consejo de Indias, México, SEP, 1985, núms. 5, 7, 9, 27, 28, 173 , 182, 206, 221, 238, 239 y 241.

29 Hubo eclesiásticos, sin embargo, que hicieron buen eco de las ideas de Erasmo; para ello basta citar a Juan Bernal Díaz de Luco, gran amigo de Vasco de Quiroga. 
Este libro forma parte del acervo de la Biblioteca Jurídica Virtual del Instituto de Investigaciones Jurídicas de la UNAM

\section{REFLEJOS DE LA MENTALIDAD \\ LAICAL DE VASGO DE QUIROGA}

Con objeto de comprender mejor el concepto de "mentalidad laical" que debe tener todo bautizado, puede ser de utilidad señalar algunos modos de cómo lo laical se reflejó en el siervo de Dios Vasco de Quiroga. ${ }^{30}$

Mencionaré algunos hechos anecdóticos a lo largo de su vida y obra. Éstos son sólo un botón de muestra de su mentalidad laical, pero que no agotan, como es lógico, su entera fisonomía.

\section{Como juez en África}

Las primeras noticias que se disponen de su actividad profesional señalan que en 1523, cuando Vasco de Quiroga tenía 35 años, recibió del rey Carlos I de España y V como emperador del Sacro Imperio Romano Germánico, el nombramiento de juez de residencia en Orán, al norte de África, que fueron tierras conquistadas por España pocos años antes. Es de suponer que laboraba para la Corona desde tiempo antes.

En su trabajo en África, Vasco de Quiroga sobresalió por su actuación como juez prudente y justo en un mundo cosmopolita, en el cual convivían personas de muchas naciones y credos. Ese periodo de su vida fue notable por su combate a los actos de corrupción, en especial de los funcionarios reales. Así pues, Vasco de Quiroga dictó sentencias contra ellos, atreviéndose incluso a condenar al mismo corregidor de Orán, y los encerró en la cárcel. Los encausados lo presionaron y buscaron influencias en eclesiásticos y miembros del Real Consejo de Castilla. Vasco de Quiroga no sólo no cedió, sino que también tuvo que sufrir un largo proceso en su contra y empeñar algunos de sus bienes para hacer

30 Muchas referencias a su vida ejemplar se recogen en Arce Gargollo, Pablo, La vida santa de Vasco de Quiroga, México, Indosoc-Usem-U. Panamericana, 2015. 
Este libro forma parte del acervo de la Biblioteca Jurídica Virtual del Instituto de Investigaciones Jurídicas de la UNAM

frente a las cargas del proceso y prevenirse contra posibles sanciones. Finalmente, Quiroga fue absuelto de todo, ganó prestigio y no sólo continuó como juez de residencia, sino que además le fue asignada otra misión más difícil y delicada, logrando la firma conclusiva de un tratado de paz con el rey de Tremecén, que se distinguió por su precisión y celeridad, y en donde Quiroga pudo introducir conceptos, inéditos en ese entonces, de respeto a la libertad religiosa y de comercio.

\section{Oidor y juez de vida coherente}

Vasco de Quiroga entró a la ciudad de México-Tenochtitlan el 9 de enero de 1531. Él llegó con todos los poderes para ejercer como oidor; es decir, siendo integrante de un cuerpo colegial que se conoció como la Segunda Audiencia, primera autoridad en el gobierno de la Nueva España.

Siendo laico, Vasco de Quiroga destacó por su vida ejemplar y coherente. Su condición de funcionario real y máxima autoridad en la Nueva España no le hizo nunca ocultar su fe cristiana ni le llevó a esconder su vida de oración y la frecuencia de sacramentos.

En el juicio de residencia practicado de oficio al entonces licenciado Vasco de Quiroga en su desempeño como oidor, se interrogó a varios testigos acerca de su actuación como funcionario real. Uno de los testigos, el canónigo don Manuel Flores, en ese entonces deán de la Catedral de México y contemporáneo del siervo de Dios Vasco de Quiroga, expresó en su testimonio esta afirmación contundente: "Creo, por Dios y en conciencia, que Quiroga nunca ha hecho conscientemente un acto que constituya un pecado mortal; y no hay fraile en la tierra que le aventaje en vivir religiosamente". ${ }^{31}$

31 Arnaldo de Yssasi, Francisco, Demarcación y descripción de Michoacán (1649), Bibliotheca Americana, 1982, vol. I, n. 1, pp. 61-204. El manuscrito se localiza en la "Ayer Collection of Americana", MS 1106. 
Este libro forma parte del acervo de la Biblioteca Jurídica Virtual del Instituto de Investigaciones Jurídicas de la UNAM

Otro testigo, fray Juan de Zumárraga, señaló lo siguiente: "Que a la verdad, el dicho Licenciado Quiroga nos da buena lección y aún reprensión para los obispos de estas partes con todo lo que él hace en gastar cuanto tiene en sus hospitales e congregaciones, e ejercitar todas las buenas obras de misericordia con ellos". ${ }^{32}$

El mismo Zumárraga, en carta que envió al rey Carlos I, expresó su beneplácito al conocer que el licenciado Quiroga había sido nombrado obispo de Michoacán, diciendo al respecto:

Siendo oidor gasta cuanto S. M. le manda dar de salario a no tener un real y vender sus vestidos para proveer a las congregaciones cristianas que tiene en dos hospitales... Lo hará harto mejor aunque no sé otro que le iguale en esta tierra y para mi es harta reprensión y tengo lo dicho y por averiguado que nos ha de hacer vergüenza a los Obispos dacá presertim a los frailes. ${ }^{33}$

\section{Prestigio profesional}

La muerte violenta del cazonci Tangáxoan Tzintzicha (febrero de 1530) causó gran malestar y rebelión en la región de los tarascos. Para efectos de la evangelización, este hecho y sus consecuencias son relevantes.

Las noticias que recibieron los integrantes de la Segunda Audiencia de lo que sucedía en Michoacán les llevó a pedir permiso a la Corona para que uno de los oidores acudiera a esa provincia e hiciera una inspección. La emperatriz autorizó la visita con una real cédula, ${ }^{34}$ y la Audiencia decidió que fuera el licenciado Quiroga quien se trasladara a la provincia de Mechuacán, y así se lo hicieron saber a la reina. ${ }^{35}$ Juan Salmerón, compañero de Vasco

32 "Juicio de residencia", en García Icazbalceta, Joaquín, Colección de documentos para la historia de México, 2a. ed., México, Porrúa, 1975, t. 4, doc. 30, pp. 89 y ss., y 190-197.

33 "Carta de fray Juan de Zumárraga...", op. cit., t. 4, pp. 149 y 150.

34 Cédula expedida en Medina del Campo, 19 de abril de 1532.

35 Paso y Troncoso, Francisco del, Epistolario de Nueva España, México, 19391942 , t. 2, pp. 218 y ss. 
Este libro forma parte del acervo de la Biblioteca Jurídica Virtual del Instituto de Investigaciones Jurídicas de la UNAM

de Quiroga en la Audiencia, declaró el motivo: "El Licenciado Quiroga podrá ocuparse de lo de Mechuacán, porque es hombre virtuoso, buen cristiano y muy celoso del servicio de Dios". ${ }^{36}$

De su llegada a Michoacán dieron cuenta los oidores en una carta que mandaron al emperador: "Tenemos carta suya que es llegado y comienza a entender en la averiguación de ello, y hasta ahora parece poca cosa. Estamos ciertos que se hará toda la diligencia posible para saber la verdad, porque así se le encargó". ${ }^{37}$

\section{Apóstol no profesional en su profesión}

El licenciado Vasco de Quiroga no era ciertamente un apóstol de profesión; sin embargo, hizo apostolado con ocasión de su trabajo profesional.

Su mentalidad laical le lleva a buscar a los otros para acercarlos a Dios. Además, Vasco de Quiroga no considera, con mentalidad clerical, que esa función sea sólo de los sacerdotes y los religiosos.

En agosto de 1533, el licenciado Quiroga llegó a Michoacán con objeto de pacificar la provincia. Se reunió con don Pedro Panza Cuinierángari, ${ }^{38}$ entonces gobernador de Tzintzuntzan, y con los principales del reino para escuchar sus quejas y reclamos. Don Vasco los movió a dejar la idolatría y los vicios; asimismo, les enseñó un panorama inmenso de las ventajas que recibirían si lograban vivir en una sociedad organizada, y los animó a realizar

36 AGI, Patronato, legajo 184, ramo 13; Paso y Troncoso, Francisco del, op. cit., t. 16, p. 20.

37 Paso y Troncoso, Francisco del, op. cit., t. 3, pp. 110 y ss.

38 Muerto el cazonci, don Francisco se hizo cargo de la gobernación de Michoacán, pues los hijos del difunto, don Francisco y don Antonio, eran de corta edad. Don Pedro gobernó hasta 1543, año en que falleció; para ese entonces había muerto don Francisco Tariácuri, el otro hijo del cazonci, y tomó el gobierno don Antonio Huitziméngari, con la natural molestia del hijo de don Pedro, don Bartolomé, quien reclamó derechos de ser el gobernador. Poco tiempo después, don Bartolomé acusó a don Antonio de abusos hacia los naturales de Tzintzuntzan. 
Este libro forma parte del acervo de la Biblioteca Jurídica Virtual del Instituto de Investigaciones Jurídicas de la UNAM

un trabajo bien hecho. También el licenciado Quiroga se detuvo en explicarles con detalle lo que era una verdadera familia y los serios inconvenientes de tener varias mujeres, práctica usual entre los tarascos. Luego, con ejemplos adecuados, don Vasco les enseñó muchos aspectos de la doctrina católica.

De los frutos de aquellos primeros meses, el licenciado Quiroga dio cuenta en el juicio de residencia que se le siguió entre 1535 y 1536 :

Yo, el dicho Lic. Quiroga fui... se estaban los naturales de la dicha provincia bestyales e ignorantes en el conocimiento de Dios nuestro Señor... e salvajes en su manera y atavíos. E después que ahí fui por el dicho mandato, e les hablé de parte de la dicha Audiencia, y di a entender las cosas del servicio de Dios nuestro Señor... y, luego se cubrieron e honestaron e entregaron ellos mismos sus ídolos que hasta entonces habían tenido secretos y encubiertos, y destruyeron sus idolatrías e entendieron las cosas como debían y se comenzaron a casar a ley e a bendición como lo manda la Santa Madre Iglesia, las mujeres las cabezas cubiertas, e a concurrir mucha gente a la doctrina cristiana, y a los sermones, misas, e a recibir el santo bautismo los que no eran cristianos. ${ }^{39}$

Además de lo que hizo en Michoacán, el licenciado Quiroga hace alusión a una notable entrevista sostenida con tarascos en su oficina en la Ciudad de México. En 1535 - lo cuenta él mismo en carta a un amigo - Vasco de Quiroga recibió en la sala de la Audiencia a don Francisco Tariácuri y don Antonio Huitziméngari, hijos del cazonci, y a don Bartolomé, hijo de don Pedro Panza Cuinierángari. Anota el licenciado Quiroga - suponemos que luego de varios días de tratar con ellos - el modo como ya entonces vivían el cristianismo, señal clara de que habló con ellos al respecto y les enseñó algunas cosas con relación a su fe: "Después informados bien de todo... y así se volvieron desta Real Abdiencia

39 "Juicio de residencia", en García Icazbalceta, Joaquín, Colección de documentos para la historia de México, Librería de J. M. Andrade, Portal de Agustinos, 1858, n. 3 (edición facsímil, México, Porrúa, 1980, t. 3, doc. 30, pp. 85 y ss.). 
Este libro forma parte del acervo de la Biblioteca Jurídica Virtual del Instituto de Investigaciones Jurídicas de la UNAM

(sic) consolados y alegres en sus tierras, donde al presente están, tan buenos cristianos y tan leales vasallos de su majestad, y de tan buena voluntad, que es para darse muchas gracias a Dios". ${ }^{40}$

Cabe destacar también el celo apostólico que mostró el licenciado Quiroga en el ejercicio de su trabajo profesional como oidor. En la Real Audiencia, él trabajaba con dos jóvenes, Cristóbal Cabrera y Pedro de Yepes. No es casual que estos dos fueran, posteriormente, los primeros sacerdotes que ordenó el obispo don Vasco al iniciar su ministerio episcopal.

\section{Responsable de su trabajo}

Vasco de Quiroga fue nombrado obispo el 8 de agosto de 1536. Luego, él recibió la ordenación episcopal a finales de 1538, poco más de dos años después; no obstante, diversos motivos retrasaron la ordenación: la dificultad para que llegaran las bulas papales; la falta de obispos que pudieran ordenarlo, y el sentido de responsabilidad de Vasco de Quiroga.

Sabemos que Vasco de Quiroga, con gran espíritu de servicio, siguió colaborando en los trabajos de la Audiencia. Así, él aceptó el 30 de noviembre de 1537 la difícil encomienda que le hizo el virrey don Antonio de Mendoza, que consistía en llevar la cuenta de los vasallos de Hernán Cortés, marqués del Valle. ${ }^{41}$ Eso significó que se tuvo que retrasar su ordenación episcopal.

\section{Resistencia a ser obispo}

No es posible saber a ciencia cierta lo que debió pasar por la cabeza y el corazón del licenciado Quiroga al conocer su nombramiento como obispo, ni tampoco las horas de oración y re-

\footnotetext{
40 Idem.

41 AAH, Colección Muñoz A/ 108 f. 91, "Mandamiento del virrey Mendoza al oidor Quiroga para la cuenta de vasallos del marqués del Valle”, México, 30 de noviembre de 1537.
} 
Este libro forma parte del acervo de la Biblioteca Jurídica Virtual del Instituto de Investigaciones Jurídicas de la UNAM

flexión previas a su aceptación. No hay dato histórico que mencione que hizo gestiones en busca del episcopado o que añoraba ese estado; en cambio, sí existe una referencia a cierta resistencia:

...me arrancaron de la magistratura y me pusieron en el timón del sacerdocio, por mérito de mis pecados. A mí, inútil y enteramente inhábil, para la ejecución de tan grande empresa; a mí, que no sabía manejar el remo me eligieron Primer Obispo de la Ciudad Michoacana. Y así sucedió que antes que aprender, empecé a enseñar, tal como de sí mismo decían, lamentándose, el padre Ambrosio y Agustín. ${ }^{42}$

La expresión "me arrancaron de la magistratura" indica su profundo amor por el ejercicio de su profesión.

\section{Amor a la verdad}

Vasco, amante de la verdad y del derecho, pide al papa que se haga una corrección a la bula de su nombramiento como obispo, pues en ella se menciona que es licenciado en teología, cuando en realidad lo es en cánones. ${ }^{43}$

\section{Separación Iglesia-Estado}

La traza de Pátzcuaro fue obra de Vasco de Quiroga. En este sentido, llama la atención la Plaza Mayor, en la cual no hay ningún edificio religioso, a diferencia de otras plazas construidas en el siglo XVI, en donde conviven el poder civil y el eclesiástico.

Don Vasco quiso dejar clara la separación de poderes, por lo que eligió la gran plaza prehispánica para sentar ahí su catedral, el palacio episcopal, el colegio de San Nicolás y el hospital.

42 Decreto de erección del obispado. Cit. por Ceballos García, Manuel Jesús, La acción pastoral de don Vasco de Quiroga, tesis doctoral, Mérida (México), Facultad de Teología de la Universidad de Navarra, 1988, p. 127.

43 Méndez Arceo, Sergio, Contribución a la historia de don Vasco de Quiroga, México, Abside, 1941, p. 201. 
Este libro forma parte del acervo de la Biblioteca Jurídica Virtual del Instituto de Investigaciones Jurídicas de la UNAM

\section{Formación de laicos}

Las primeras semillas de la fe llegaron a la provincia de Michoacán por los laicos. La conversión se dio en 1525 con el cazonci Tangáxoan Tzintzicha (rey tarasco), quien con el bautismo recibió el nombre de Francisco, y la de su hermano adoptivo, Pedro Panza Cuinierángari, así como el bautismo de Alonso Uisie, yerno de Francisco, y los nahuatlatos Gonzalo Xuarez Cuyçique y Alonso de Ávalos Acaysante. Sabemos también de la conversión de don Francisco Tariácuri y don Antonio Huitziméngari, hijos del cazonci, y de don Bartolomé, hijo de don Pedro Panza Cuinierángari.

Estos hechos marcan con mucha fuerza el inicio de una cristianización peculiar y diversa a lo sucedido en otros lugares de la Nueva España. Los laicos están antes que cualquier religioso.

Desde el principio don Vasco intuyó que debía formar bien a los laicos y fomentó algunas instituciones en donde la vida cristiana se pusiera en uso, así como lugares en los que todos practicaran, de modo habitual, en medio de su quehacer y de la vida familiar lo que es vivir en cristiano. De esa intuición genial surgieron el pueblo-hospital, las guataperas y los hospitales de la Concepción. ${ }^{44}$

Vale la pena hacer notar la visión que tuvo Vasco en cuanto a la imperiosa necesidad de formar a la mujer de un modo especial, ya que es ella la que debe - dice - "presidir en la casa". El valor ejemplar de la mujer es parte fundamental en esa recomposición social que deseó hacer. De algún modo, se adelantó a esas instituciones modernas que están enfocadas a la mujer para aprender todo lo referente a la administración de los hogares o de otras instituciones de servicio.

Los laicos fueron los colaboradores habituales en la labor pastoral del obispo, quien confió en ellos desde el principio para que le ayudaran en su misión pastoral. Estamos delante de algo

44 Arce Gargollo, Pablo, Tata Vasco de Quiroga, emprendedor y visionario social en el siglo XVI, México, ECA, 2014. 
Este libro forma parte del acervo de la Biblioteca Jurídica Virtual del Instituto de Investigaciones Jurídicas de la UNAM

inédito en la evangelización primera en la Nueva España, pues don Vasco de Quiroga, con mentalidad laical y secular, entendió bien el papel de los laicos. ${ }^{45}$

\section{Decisión de asistir al Concilio de Trento}

Los gobernantes españoles, además de intentar mantener a las Indias en un monopolio comercial cerrado, controlando férreamente la actuación de otros Estados, procuraron aislar los territorios americanos conquistados de la sede romana. Asimismo, ellos establecieron que los obispos y eclesiásticos residentes en las Indias no tuvieran relación directa con el papa y las congregaciones romanas, de modo que sus actuaciones se canalizaron a través del Consejo de Indias. ${ }^{46}$ Esto no se logró del todo a la luz de abundantes testimonios históricos que muestran la existencia de relaciones directas, aunque fueron mal vistas por la Corona.

La política de aislamiento de los obispos americanos hacia Roma abarcó desde la prohibición de participar en el Concilio de Trento, efectuar personalmente la visita ad límina, junto con el envío de la memoria informativa correspondiente, hasta evitar el trato con el nuncio apostólico en España. El cauce informativo habitual había de ser el embajador de España en Roma. Se estableció con carácter obligatorio el "pase regio" a las bulas y los breves pontificios para que pudieran tener vigencia en las Indias.

El papa Paulo III publicó una bula el 2 de junio de 1536, por la que convocaba a todos los obispos, de no mediar enfermedad o causa grave, a un concilio universal, que se celebraría en Mantua a partir del 23 de mayo del año siguiente. Diversas dificultades hicieron que se fijara la celebración hasta 1545 en la ciudad

45 Arce Gargollo, Pablo, Vasco de Quiroga, jurista con mentalidad secular, México, Porrúa, 2007.

46 Sánchez Bella, Ismael, Iglesia y Estado en la América española, España, Eunsa, 1990, p. 55 . 
Este libro forma parte del acervo de la Biblioteca Jurídica Virtual del Instituto de Investigaciones Jurídicas de la UNAM

de Trento. A México llega la bula cuando el licenciado Vasco de Quiroga es todavía obispo electo.

En México existían, entonces, sólo cinco obispos. Ante la convocatoria del papa, los obispos de Nueva España se reúnen y deciden consultar al emperador sobre si ellos tienen la obligación de asistir por la enorme distancia que los separa de Trento, las dificultades del viaje y el serio inconveniente de dejar abandonadas sus diócesis. Así, fray Juan de Zumárraga, obispo de México, manifestó a la Corona - en cartas de febrero y noviembre de $1537-47$ su deseo de participar en el Concilio de Mantua; ${ }^{48} \sin$ embargo, después tendrá que excusarse. El obispo de Tlaxcala desde 1526, fray Julián Garcés, entonces de edad muy avanzada, enfermo y en el proceso de cambio de su sede de Tlaxcala a Puebla, también se excusó. Lo mismo hicieron Francisco Marroquín, ${ }^{49}$ obispo de Guatemala - el primero consagrado en la Nueva España-, y Juan López de Zárate, ${ }^{50}$ obispo de Antequera (Oaxaca), argumentando que llevaban muy pocos meses en sus respectivas diócesis y estaban a una distancia considerable.

Don Vasco, en cambio, decide acudir al llamado del papa. Su mentalidad laical y jurídica le dice que no debe hacer caso a

47 "Carta del 8 de febrero de 1537 sobre su decisión de ir al Concilio General de Mantua"; "Carta del 13 de febrero de 1537, sobre lo mismo" (García Icazbalceta, Joaquín, Apéndice, doc. n. 50, pp. 25-28); "Carta sobre la intención de ir al Concilio General, junto con Marroquín y Zárate, el 30 de noviembre de 1537” (Lorenzana, Concilio, II, apéndice, n. 1).

48 El 2 de junio de 1536 el papa Pablo III convocó un concilio a realizarse en Mantua para el mes de mayo siguiente, pero la oposición de los príncipes protestantes, así como el rechazo del duque de Mantua para asumir la responsabilidad de mantener el orden, frustraron el proyecto. Entonces, el papa publicó una nueva bula, convocando un concilio en Vicenza el lo. de mayo de 1538; sin embargo, tampoco pudo llevarse a cabo. Finalmente, el 13 de diciembre de 1545 el Concilio de Trento celebró su primera sesión. En siete sesiones - la última el 3 de marzo de 1547- discutieron las cuestiones más importantes de fe y disciplina.

49 Fray Juan de Zumárraga ofició la ceremonia el 8 de abril de 1537, siendo ésta la primera en su tipo en celebrarse en las Indias.

50 López de Zárate fue consagrado en Madrid y tomó posesión de su sede el 28 de septiembre de 1536. 
Este libro forma parte del acervo de la Biblioteca Jurídica Virtual del Instituto de Investigaciones Jurídicas de la UNAM

la prohibición real de participar en el Concilio de Trento, sino a la llamada papal. El primer obispo de Michoacán considera en 1542 que tiene la posibilidad de ir al Concilio, que es su obligación y que lo puede hacer. Deja a cargo de su diócesis a fray Alonso de la Veracruz, lector en filosofía en el convento agustino de Tiripetío, y decide embarcarse en Veracruz rumbo a España, para luego irse a Trento.

En ese entonces viajar era una aventura en donde se ponía en riesgo la vida. No hay datos de lo que sucedió exactamente, pero tal parece que después de algunos meses logró embarcarse, aunque el barco tuvo una avería, y como "hacía demasiada agua" decidieron volver al puerto. Don Vasco no pudo asistir al importante Concilio de Trento y regresó a su diócesis, pero no se plegó a la voluntad del rey.

\section{No escuchó el canto de las sirenas}

Los diversos conflictos con los que se enfrentó don Vasco y la necesidad de aclarar acusaciones y proteger sus fundaciones lo llevaron a tomar la decisión de ir a España y realizar las gestiones necesarias para lograr sus objetivos.

En 1547, don Vasco va a España y permanece en la península hasta 1554. ${ }^{52}$ En España, él dedicó mucho tiempo en la Corte, en Valladolid, donde trabaja intensamente en los aspectos jurídicos.

Cristóbal Cabrera, su secretario, relata lo siguiente:

Efectivamente, siendo ya obispo, y más que sexagenario, no tuvo reparo en emprender largo y penoso viaje a España, en donde

51 Moreno, Juan Joseph, Fragmentos..., cit., cap. XIV.

52 Probablemente, Vasco de Quiroga viajó en la flota que salió de Veracruz el 23 de mayo de 1547 y quizá en el mismo navío en el que vuelve a España el visitador Francisco Tello de Sandoval, canónigo de Sevilla, inquisidor en Toledo y miembro del Real Consejo de Indias. Cfr. Carrillo Cázares, Alberto, Vasco de Quiroga: la pasión por el derecho. El pleito con la Orden de San Agustín (1558-1562), Michoacán, Colegio de Michoacán, 2003, t. 1, pp. 64 y 65. 
Este libro forma parte del acervo de la Biblioteca Jurídica Virtual del Instituto de Investigaciones Jurídicas de la UNAM

estuvo varios años arreglando en el Consejo de Indias algunos negocios arduos y difíciles tocantes a los neófitos e infieles; estando ahí, un antiguo condiscípulo, muy influyente, Patriarca de las Indias y Canciller del reino, le ofrecía un pingüe obispado de España; el señor Quiroga le respondió: "Reverendísimo padre mío, todo cuanto decís es muy bueno; mas ¿no os parece indigno e indecoroso de un siervo fiel que, después de haberme dado el señor una esposa amantísima, la deje y abandone así fuere por el mundo entero? Lejos de mí tal acción. Mientras yo viva, apacentaré mis corderos y mis ovejitas, que son los indios; procuraré atraer al aprisco de Cristo a los convertidos y a los que están todavía por convertirse; y trabajando hasta morir, pondré voluntariamente mi vida por ellos (Jn 10, 15)". Así fue que, arreglados todos sus negocios, al poco tiempo se hizo a la vela regresando a su obispado, a su amada esposa, como él solía llamarle. ${ }^{53}$

\section{Conflictos jurídicos}

Don Vasco de Quiroga, por vocación y profesión, enfrentó toda su vida problemas jurídicos; en efecto, buscó siempre que todos, sin excepción, cumplieran con la ley. Su mentalidad laical le permitía distinguir perfectamente el ámbito religioso del civil, así como lo que constituía un trabajo profesional sin mezclar asuntos internos con externos, y que católico es quien no se sirve de la Iglesia y pretende servirla del mejor modo posible, con el cumplimiento responsable de las obligaciones personales.

El derecho era su pasión; pues bien, se puede calificar a don Vasco como un hombre con pasión por el derecho, tanto por la manera de ejercerlo como por los sufrimientos que le causa. Lo estudia, lo aplica y busca que los demás se guíen por la ley, ya que el Estado de derecho es la única forma posible de convivencia entre los hombres. Algunos lo criticaban diciendo que siempre

53 De Sollicitanda Infidelium Conversione. Fusta illud Evangelicum Lucae XIIII, Compelle Intrare, Christophori Cabrerae Presbyteri Theologi Tractatus, ad Amicum quaerentem ejusdem Evangelici verbi expositionem ac sensum, Biblioteca Vaticana, Colección Barberini, Códice Misceláneo Vat. Lat. 5026. 
Este libro forma parte del acervo de la Biblioteca Jurídica Virtual del Instituto de Investigaciones Jurídicas de la UNAM

estaba en pleitos; quizá sea mejor decir que continuamente se encontraba defendiendo el derecho de los demás.

De esta manera se entienden los pleitos jurídicos que tuvo que sostener con otros obispos, con religiosos y con autoridades reales, incluido el virrey, así como con particulares prepotentes.

\section{Gonclusiones}

Nos parece que hay al menos tres consecuencias que se derivan necesariamente de la actuación de la persona que tiene mentalidad laical y que se dan plenamente en la vida de Vasco de Quiroga.

Un católico con mentalidad laical debe:

1) Ser lo suficientemente honrado para asumir siempre la responsabilidad por las acciones propias.

2) Ser lo suficientemente cristiano para respetar a los otros - cristianos o no- que proponen en materias opinables, soluciones diversas a la que uno sostiene.

3) Ser lo suficientemente católico para no servirse de la Iglesia, mezclándola en banderías humanas. ${ }^{54}$

Un conocimiento más profundo de la vida de Vasco de Quiroga ayudará a todos a entender mejor el papel que cada uno debe desarrollar en la vida de la Iglesia y de la sociedad.

Con ocasión del 450 aniversario de su fallecimiento, Vasco de Quiroga nos puede interpelar para que mantengamos una mentalidad laical.

\section{BibliografíA}

"Juicio de residencia", en GARCía ICAZBALCETA, Joaquín, Colección de documentos para la historia de México, 2a. ed., México, Porrúa, 1975.

54 Inspirados en la enseñanza de san Josemaría Escrivá. Véase Conversaciones con monseñor Escrivá de Balaguer, Madrid, Rialp, 1968, n. 117. 
Este libro forma parte del acervo de la Biblioteca Jurídica Virtual del Instituto de Investigaciones Jurídicas de la UNAM

Arce Gargollo, Pablo, Vasco de Quiroga, jurista con mentalidad secular, México, Porrúa, 2007.

, Tata Vasco de Quiroga, emprendedor y visionario social en el siglo XVI, México, ECA, 2014.

— L La vida santa de Vasco de Quiroga, México, Indosoc-Usem-U. Panamericana, 2015.

Brockman, Eric, The Two Sieges of Rhodes: The Knights of St. John at War, 1480-1522, Nueva York, Barnes \& Noble, 1995.

GARrillo CázARES, Alberto, Vasco de Quiroga: la pasión por el derecho. El pleito con la Orden de San Agustín (1558-1562), Michoacán, Colegio de Michoacán, 2003.

Conversaciones con monseñor Escrivá de Balaguer, Madrid, Rialp, 1968.

Delgado Pérez, María Mercedes, "Vasco de Quiroga y la génesis de un códice fronterizo", IX Estudios de Frontera, Universidad de Sevilla, 2013.

Escobar Olmedo, Armando Mauricio, Los escudos de don Vasco de Quiroga, Morelia, 1999.

García ICAZBALCETA, Joaquín, Don fray Fuan de Zumárraga, primer obispo y arzobispo de México, México, Porrúa, 1947.

GonzÁlez, Francisco Antonio (ed.), Colección de cánones de la Iglesia española: concilios del siglo XV en adelante, Madrid, 1855, t. V.

Herrejón, Carlos, Información en derecho del licenciado Quiroga sobre algunas provisiones del Real Consejo de Indias, México, SEP, 1985.

MÉndez ARCEO, Sergio, Contribución a la historia de don Vasco de Quiroga, México, Abside, 1941.

Ollero, Andrés, España: ¿un Estado laico? La libertad religiosa en perspectiva constitucional, Navarra, Thomson-Civitas, 2005.

Paso y Troncoso, Francisco del, Epistolario de Nueva España, México, 1939-1942.

Silva, Álvaro, Tomás Moro: un hombre para todas las horas, Madrid, Marcial Pons, 2007. 
Este libro forma parte del acervo de la Biblioteca Jurídica Virtual del Instituto de Investigaciones Jurídicas de la UNAM

\section{LA GATEDRAL PERDIDA DE DON VASGO}

Vasco de Quiroga, innovador en arquitectura eclesiástica

\section{Armando Mauricio ESCOBAR OLMEDO*}

Sumario: I. Introducción. II. Semblanza de don Vasco. III. La utopia "realizada". IV. Don Vasco oidor. V. Don Vasco obispo. VI. La Catedral perdida de don Vasco. VII. Hallazgos arqueológicos visuales y con Geo-radar. VIII. Conclusiones.

IX. Fuentes de consulta.

\section{INTRODUGCIÓN}

Mucho se ha escrito sobre la labor evangelizadora, educativa y social de don Vasco de Quiroga, pero ha pasado desapercibida una acción interesante de tan venerable humanista: la de innovador en arquitectura eclesial y en urbanismo. En efecto, don Vasco fue fundador de ciudades (la de Granada en Tzintzuntzan y la Ciudad de Michoacán en Pátzcuaro), de hospitales-pueblos (Santa Fe de México y la Laguna) y de centros educativos (Colegio de San Nicolás Obispo). Asimismo, él se desempeñó como constructor de iglesias; por ejemplo, las de sus dos hospitales-pueblos de Santa Fe, la catedral provisional en Pátzcuaro - Iglesia de la Compañía- y, principalmente, la magna Catedral de San Salvador (objeto de este trabajo), la que lamentablemente no pudo terminar por la incomprensión de su tiempo y los grandes obstáculos que se le opusieron por intereses muy particulares. También don Vasco fue el diseña-

* Presidente de la Academia Michoacana de Historia de la Sociedad Mexicana de Geografía y Estadística, corresponsalía Morelia. 
Este libro forma parte del acervo de la Biblioteca Jurídica Virtual del Instituto de Investigaciones Jurídicas de la UNAM

dor del núcleo de la actual ciudad de Pátzcuaro, que será tanto sede episcopal como la cabecera política de la provincia de Michoacán, e incluso realizó el escudo de armas de la ciudad, el cual le fue otorgado por real provisión, así como otras muy diversas tareas que se echó a cuestas, todas estas conocidas pero no valoradas en su verdadero significado.

Don Vasco fue muy cuestionado por la extraña traza y las grandes dimensiones de su iglesia catedral de cinco naves, de la cual existe duda si sólo la imaginó o si en realidad la trazó y cimentó. De sus verdaderas dimensiones y de su impactante construcción mucho se ha especulado, basten para ello mencionar los siguientes comentarios: el virrey Luis de Velasco escribió al rey sobre lo que vio al visitar la obra de la catedral en la Ciudad de Michoacán-Pátzcuaro y señaló: “...será el mejor templo que haya en Indias, acabado..."; ${ }^{1}$ el sucesor de don Vasco en el obispado, don Antonio Ruiz de Morales, recién llegado a su diócesis escribe con gran admiración al rey desde la Ciudad de Michoacán (1568) al conocer la construcción de la iglesia catedral, y le dice: "es una cosa tan extraordinaria y tan diferente de todas las trazas que yo he visto, que no la sabré dar a entender...".2 En el siglo XVIII, el famoso rector del Colegio de San Nicolás, el licenciado Juan José Moreno - autor de la primera gran biografía de Quiroga-, señala lo siguiente: "La otra iglesia que mandó levantar... era tan magnífica, que ha llenado enteramente las ideas de cuantos hacen memoria de ella: unos dicen que se seguía la planta del templo de San Pedro; otros que era de cinco naves... y todos sostienen que acabada esta obra sería la octava maravilla...".3

1 Archivo de los Duques del Infantado, libro X, "Libro en que se asientan a la letra las cartas que el Virrey (don Luis de Velasco) mi Señor escribía a su Majestad...”. Es libro copiador. Carta del virrey, Ciudad de México, 20 de mayo de 1556, fol. $195 \mathrm{v}$.

2 Archivo General de Indias, Audiencia de México, legajo 374, Ciudad de Michoacán, 27 de febrero. En lo sucesivo AGI.

3 Moreno, Juan José, Fragmentos de la vida y virtudes del V. Illmo. y Rmo. Sr. Dr. D. Vasco de Quiroga, México, 1766, p. 48. El original está en el fondo antiguo de la Biblioteca Pública Universitaria de la UMSNH. 
Este libro forma parte del acervo de la Biblioteca Jurídica Virtual del Instituto de Investigaciones Jurídicas de la UNAM

Muchos consideraron la intención de don Vasco (el querer hacerla) como una locura. En el pasado siglo XX, el gran conocedor de la arquitectura mexicana, el doctor Carlos Chanfón Olmos, comentó acerca de los estudios realizados sobre el proyecto catedralicio de don Vasco: “¿Hasta qué grado fue una locura?, que el claro de la bóveda del presbiterio proyectada por don Vasco mediría 42.426 m. y el de la de San Pedro unos 42.09m... ¡Qué grandiosa locura la del obispo Don Vasco! ¡Qué ruines los que estorbaron tan magna obra...!". 4

Durante las largas, inolvidables y agradables charlas sostenidas con el ilustre quiroguiano Silvio Zavala Vallado, con motivo de las jornadas que llevaban su nombre y que nos tocó por suerte organizar con la Universidad Michoacana en siete ocasiones, tuvimos la oportunidad de tratar este tema varias veces, particularmente en la ciudad de Pátzcuaro, y las preguntas recurrentes del doctor Zavala eran las siguientes: ¿cómo cree usted que sería la catedral inconclusa de don Vasco?, ¿cuál sería su tamaño real?, ¿se harían las cinco naves realmente?

Entonces, tomé la intención de realizar las investigaciones necesarias para saberlo, pues era un tema que también me inquietaba y del que leí en muchos de los largos expedientes que había reunido en micropelícula, principalmente, del Archivo General de Indias durante mis diversas estancias en tan reconocido acervo, 35 de los cuales seleccioné para integrar el expediente histórico documental para la canonización de don Vasco de Quiroga y que sumaron más de 8,000 hojas - dieciséis páginas - de valioso material respecto a este personaje y su entorno, la gran mayoría de éste inédito. Una muy pequeña parte de uno de los expedientes referentes a la citada catedral es de lo que trata este trabajo, en el que hemos insertado una gran cantidad de referencias documentales, muchas de ellas de don Vasco, para que su voz se escuche de nuevo y se conozca a Quiroga por sí mismo, sin necesidad de tener que interpretarlo.

4 Chanfón Olmos, Carlos, La Catedral de San Salvador. El gran proyecto de don Vasco de Quiroga, México, UNAM, Instituto de Investigaciones Estéticas, 1986, p. 48. 
Este libro forma parte del acervo de la Biblioteca Jurídica Virtual del Instituto de Investigaciones Jurídicas de la UNAM

Este trabajo consta de las siguientes partes: 1) semblanza de don Vasco; 2) la utopía realizada; 3) don Vasco oidor; 4) don Vasco obispo; 5) Quiroga y su magna Catedral de San Salvador; 6) la catedral perdida de don Vasco; 7) hallazgos arqueológicos visuales y con Geo-radar, y 8) las conclusiones.

\section{SEMBLANZA DE DON VASCO}

De profundas raíces gallegas, cuyos orígenes se pierden en el remoto y tenue amanecer del bajo medievo, la connotada familia Keiroga había tomado con orgullo el apellido de la pequeña e importante villa situada cerca del transitado camino de Santiago, en la actual provincia de Lugo. Sus umbrosos bosques y quebrados montes ocultaban los restos de añejos castillos que ostentaban en sus labras las heroicas historias de cruentas batallas, que ha trozos contaban las hazañas de sus valerosos antepasados, quienes eran ilustres caballeros de las órdenes de Santiago y San Juan de Jerusalén.

En las grandes reuniones familiares, el pequeño Blas o Blasco de Keiroga y Alonso de la Cárcel escuchaba con asombro de los labios de su padre, don Blasco o Vasco de Queiroga - gobernador del Priorazgo de San Juan - , las andanzas de su abuelo, don Pedro Vásquez de la Somoza - dueño del Castillo de Lor-, y de su bisabuelo, don Gonzalo Rodríguez de Valcárcel y Balboa. Pero de todas las que más le impactaban, seguramente, eran las del hermano de su abuela paterna, don frey Gonzalo de Quiroga, gran prior en Castilla de la Hospitalaria Orden de San Juan de Jerusalén, quien había peleado contra los turcos en el asedio de la Isla de Rodas (sede de la Orden), dirigiendo una enorme barcaza y perdiendo la vida por defender la causa de la fe en el lejano año de 1454; sus restos embalsamados fueron depositados en un suntuoso mausoleo en la Iglesia de Santa María de Alcarria. Hasta allá había llevado don Vasco a sus tres hijos: Álvaro (el mayor) y a Vasco y Constanza (los más pequeños), para que reverenciaran 
Este libro forma parte del acervo de la Biblioteca Jurídica Virtual del Instituto de Investigaciones Jurídicas de la UNAM

aquel lugar donde reposaba el valiente caballero y honraran con valor su memoria.

No menos interesantes le parecían a los tres hijos escuchar a su madre, doña María Alonso de la Cárcel, cómo en la Villa de Arévalo - en donde ella naciera - sus tíos y abuelos también escenificaron rudas peleas para defender el castillo de los moros. Asimismo, ellos oían cómo frey Gonzalo había concertado su matrimonio con don Vasco, que a la sazón vivía en Madrigal, y ella, dejando el hogar paterno, pasaría a vivir en el cercano pequeño poblado - sede un tiempo de la Corte-, pero visitando con frecuencia a su ama y señora la princesa Isabel, futura reina de Castilla.

Ahí en Madrigal - luego llamada de las Altas Torres-, en medio de la extensa y larga llanura castellana denominada "La Moraña", entre dos pequeños riachuelos (el Trabancos y el Zapardiel), vio la luz primera Blasco de Quiroga y sus dos hermanos, en un año que unos decires ponen en la década de los ochenta del siglo XV y otros en 1470, la cual es la que nos parece cierta. Si bien años más años menos, no creemos que incidan en una vida tan longeva como plena de acción.

El pequeño Vasco recibió con sus hermanos y primos las acostumbradas enseñanzas de las amigas o maestras que acudían a sus casas a preparar a los pequeños. El pequeño Vasco acompañaba a su padre en la visita a sus tierras de Zapardiel, asistiendo puntualmente a misa los domingos en la Iglesia de San Nicolás, en donde había sido bautizado. Lo que más impresionaba al pequeño Vasco era visitar la tierra paterna en Keiroga o Quiroga, en obligado peregrinar a la tumba del apóstol Santiago en la ciudad de Compostela y pasar temporadas con su tío frey Álvaro de Quiroga, comendador de Hospitalaria Orden de San Juan de Jerusalén, a la cual estaban muy ligados sus antepasados y varios familiares, en la fría Villa de Keiroga, solar de sus pasados y en cuyo Hospital se encontraban muchos de ellos sepultados.

Ya joven pidió ingresar como postulante a la mencionada Hospitalaria Orden, sabiendo de antemano los rigores que de- 
Este libro forma parte del acervo de la Biblioteca Jurídica Virtual del Instituto de Investigaciones Jurídicas de la UNAM

bería sufrir. Vasco pasó un año de noviciado y seis meses de caravanas, las que por lo general se hacían en la recuperada Isla de Rodas.

En su memoria quedó grabado firmemente el venturoso día de su profesión como caballero, jurando guardar por siempre los tres votos esenciales: la obediencia, la pobreza y la castidad. De rodillas sobre un cojín de terciopelo carmesí, vestido todo de blanco y llevando en la mano un cirio encendido, Vasco escuchó con devoción la misa; cerca de él se encontraban en una mesa las resplandecientes espuelas doradas, la espada envainada, el manto capitular, el brideo y el misal cerrado. Sus ojos brillaron intensamente cuando se le dijo: "iCaballero, tomad esta espada! Su filo está inflamado por la Fe, por la punta, la Esperanza y por la guarnición, la Caridad, ¿Juras usarla para defender por siempre y a costa de tu vida a los pobres injustamente oprimidos, a las viudas y a los huérfanos y a defender la Fe Católica?”. El “¡Sí juro!” resonó por toda la iglesia y quedó grabado firmemente en su corazón; su destino estaba escrito.

Siendo ya caballero, Vasco decidió continuar sus estudios: primero como bachiller, para lo cual estudió tres años, y luego los superiores, seguramente en la Universidad de Salamanca, ya que ésta era la reina de las universidades hispanas, en donde renombrados maestros impartían las mejores cátedras de su tiempo. Hombre de justicia se decidió por el derecho, cursando lo siguiente: Institutas y Digesto para derecho civil; prima, vísperas y escrituras para teología, y clementinas, decretos y decretales, entre otras, para el derecho canónico. Vasco estudió con gran dedicación y empeño, además de que no existe duda que tuvo excelentes maestros que le dejaron una profunda huella en sus actuaciones judiciales, iy vaya que le sirvieron! como eficaces herramientas en su largo desempeño como impartidor de justicia, hombre modelo para aprender, para enseñar y para actuar.

La presencia del joven abogado en la Corte fue constante como comisionado en importantes negocios; uno de ellos le llevó a la recién conquistada Orán, en África, a principios de 1525, como juez de residencia, y más tarde como parte de la embajada 
Este libro forma parte del acervo de la Biblioteca Jurídica Virtual del Instituto de Investigaciones Jurídicas de la UNAM

que firmará el tratado de paz entre el rey de Tremecén, Muley Abdulá, y el ahora emperador Carlos V, quien lo confirmó en la ciudad de Granada, en donde se encontraba también don Vasco. Estos ires y venires le permitieron a Quiroga conocer los trabajos que en la cercana Santa Fe se realizaban para convertir a los musulmanes infieles al cristianismo; él pronto tendrá la oportunidad de seguir el ejemplo.

\section{LA UTOPÍA "REALIZADA"}

Apasionado de la buena lectura, Vasco recordaba años más tarde cuando acompañaba a la Corte de Burgos a Madrid; ahí, leía y comentaba con algunos amigos, entre ellos el célebre pensador Bernal Díaz de Luco, una obra de don Antonio de Guevara, un pasaje del Libro áureo de Marco Aurelio, así como su obra denominada Menosprecio de corte y alabanza de aldea, en el que anota: "es privilegio de aldea, que para muchas cosas haya tiempo cuando el tiempo es bien repartido... y así quede tiempo para leer un libro, oír misa en la iglesia, visitar a los enfermos, irse de caza por los campos y trabajar en ellos...". ${ }^{5}$

Para 1529, a don Vasco le encontramos en Murcia en alguna real comisión, y ahí recibió el llamado urgente de la reina gobernadora, doña Isabel de Portugal, esposa de Carlos V, para que marchara inmediatamente a Madrid con el objeto de tratar con él "...algunas cosas de nuestro real servicio...". Don Vasco acató la orden y se presentó ante la reina, la cual le ofreció la delicada misión de marchar a la Nueva España como oidor de la Real Audiencia. Don Cristóbal de Cabrera — su fiel discípulo, amigo y confidente, y quien nos dejó los primeros rasgos biográficos de Quiroga - narra que angustiado el futuro obispo por no saber cuál cargo aceptar de entre los varios que se le ofrecían tanto en la península como en las Indias y urgido para decidirse, entró en

5 Guevara, Antonio de, Menosprecio de corte y alabanza de aldea, Buenos Aires, Espasa-Calpe, 1947. 
Este libro forma parte del acervo de la Biblioteca Jurídica Virtual del Instituto de Investigaciones Jurídicas de la UNAM

la iglesia de un monasterio con el firme propósito de no salir de éste hasta haber elegido alguno. Acabando de entrar, se arrodilló recitando con fervor el salmo que dice: "Entro en tu morada y me postrerno... ¡Oh Señor, condúceme a tu justicia...!”, , ${ }^{6}$ y escuchó a unos monjes que cantaban y que a manera de respuesta le señalaban: "...Sacrificad, sacrificios de Justicia y esperad en el Señor, son muchos los que claman ¿quién vendrá a favorecernos?”. ${ }^{7}$ Meditando sobre lo que escuchaba, él señaló: "¡Verdaderamente que aquellas palabras me tocan y corresponden!. Bendigo a Dios que es quien me adoctrina (Ps. 15, 7), quien me llama al camino, para que bajo su protección me haga a la vela cuanto antes, y atravesando el vasto Océano, pueda ayudarle en la conversión de los indios a la Fe...". 8

Tal fue el impacto de aquellas palabras que él las mandó dibujar y bordar en forma circular en su escudo de armas y blasones, que contenía los cuatro cuarteles: el de los dados plateados con seis puntos cada uno en campo rojo, por la familia Somoza; las estacas de plata en campo verde, por la familia Vázquez de Quiroga; las estacas de oro en campo rojo, por la familia Valcárcel, y un árbol frutado en campo rojo, por la familia Quiroga. Tras este escudo, como caballero que era, se encontraba la cruz de la Hospitalaria Orden de San Juan de Jerusalén, llamada luego de Malta. Me complace comentar que se ha encontrado en el Archivo de la Orden la profesión que don Vasco hizo como caballero, lo que ha confirmado plenamente mi propuesta.

Aceptado el ofrecimiento real, la reina dirige el 6 de enero de 1530 una carta a don Vasco, en la que le avisa haber sido nombrado por uno de los oidores de la Real Audiencia de la Nueva España y le pide vaya a verla, pues desea "despacharlo" brevemente a cumplir su oficio.

6 Ps. 5, 8-9.

7 Ps. 4, 6-7.

8 Información en derecho, biografia e ideario, Morelia, Gobierno del Estado de Michoacán de Ocampo-Universidad Michoacana de San Nicolás de Hidalgo, Centro de Estudios sobre la Cultura Nicolaita, 1992, pp. 33 y 34. 
Este libro forma parte del acervo de la Biblioteca Jurídica Virtual del Instituto de Investigaciones Jurídicas de la UNAM

\section{DON VASCO OIDOR}

Llegado a la Nueva España al finalizar 1530, don Vasco se dedicó de inmediato y de tiempo completo, junto con sus compañeros oidores de la Real Audiencia, a la resolución de todos los problemas grandes y pequeños. Así, en su carta del 14 de agosto de 1531 - es decir, apenas seis meses de su arribo a la Ciudad de México- le explica al rey la urgente necesidad de hacer nuevas poblaciones:

También escribimos sobre ciertas poblaciones nuevas de indios que conviene mucho hacerse, que estén apartadas de las viejas... que trabajando, se podrán muy bien sustentar rompiendo y cultivando los dichos baldíos, y ésta es sin duda una gran cosa y muy útil y necesaria... Y yo me ofrezco con ayuda de Dios a poner y plantar un género de cristianos a las derechas como todos debíamos ser, y Dios manda que seamos, y por ventura como los de la primitiva iglesia... ${ }^{9}$

No podemos entender la magnitud de sus trabajos sin antes recordar la desastrosa actuación de la Primera Audiencia encabezada por Nuño Beltrán de Guzmán, quien como nuevo "Atila" había arrasado todo a su paso, dejando tras de sí desolación y muerte, y vendiendo a una gran cantidad de naturales como esclavos, incluso a pequeños de tres y cuatro años, los cuales marchaban con sus madres en grupos de cinco en cinco atados por el cuello y con grandes marcas de hierro al fuego que ocupaban gran parte de sus mejillas. Toda la colonia se encontraba en efervescencia; por ello se necesitaba que los nuevos oidores e impartidores de justicia fueran de tal capacidad, honestidad y firmeza, que lograran apaciguar los ánimos con imparcialidad y justicia. Los indios clamaban por ella y pedían la devolución de sus propiedades, el respeto a sus pueblos y familias, y el regreso de sus hermanos de sangre arrancados de sus casas y comunidades, quienes eran obligados a trabajar en largas y extenuantes jornadas. En el cen-

$9 \quad$ AGI, Real Patronato, 184, R. 15. 
Este libro forma parte del acervo de la Biblioteca Jurídica Virtual del Instituto de Investigaciones Jurídicas de la UNAM

tro de esa vorágine se encontraban Quiroga y los otros oidores, trabajando incansablemente en agotadores días y resolviendo con gran dedicación y entusiasmo caso por caso, siempre teniendo presente como primer principio a la justicia. Escuchemos lo que Quiroga decía al respecto:

...no es justo que nadie se enriquezca con pérdida ajena... (y si los naturales hubieren estado de acuerdo en ser esclavos)... ningún pacto particular, ni por servicio, ni ministerio, ni transcurso de tiempo (...puede el natural) perder su condición de hombre libre, pues es y ha sido libre... (sin embargo) este diablo de interés y codicia desenfrenada e increíble hay en estas partes por hacerlos esclavos, que dicen que acá ellos se alzan y rebelan... son informes de malicia de gentes codiciosas que acá pasan, y allá informan... ¿qué es menos mal? Perder la vida o caer en manos de este hierro, porque el herrado ha de ir necesariamente a parar a la sepultura de las minas, donde no solamente morirá una vez, y esta sería muy breve, sino que el tiempo que viviera, morirá viviendo como en el mismo infierno... Lo que hacen estos pobres naturales, es huirse a los montes y breñas, porque con tantas crueldades que les hacemos los tenemos espantadizos e indómitos, huyéndose y escondiéndose en los resquicios de las peñas, de toda gente española, como de la misma muerte y pestilencia, que parece que por doquiera que van los españoles los sigue, pero no se rebelan como nosotros impropiamente decimos, sino toman el huir, como la liebre, como defensa natural, y así huyen las ovejas delante de los lobos y escóndense tristes de miedo y temor. Cierto muy grande y cargosa ceguedad es esta... ${ }^{10}$

En Michoacán, la provincia se encontraba también muy revuelta tanto por el cobarde asesinato del gran cazonci Tangáxoan Tzintzicha (conocido luego como don Francisco) como por los maltratos y despojos a los michoacanos, en particular por los encomenderos y corregidores. A ella vino Quiroga y logró, a su vez, apaciguar los ánimos y castigar a quienes infringían la ley y daban malos tratos a los indios. De estos años (1532-1533) datan las fun-

10 Herrejón Peredo, Carlos, Información en derecho, México, SEP, 1985, pp. 153-157. 
Este libro forma parte del acervo de la Biblioteca Jurídica Virtual del Instituto de Investigaciones Jurídicas de la UNAM

daciones de los pueblos-hospitales de Santa Fe tanto de México como de la Laguna, verdaderos oasis para los mexicas y tarascos. Su principal objetivo era lograr reunir en un lugar a los naturales para que se les enseñara a trabajar la tierra con nuevas técnicas, así como los oficios, las artes y la religión, sin que fueran oprimidos y vejados, y que los aprendieran dentro de un orden y respeto entre ellos mismos y para con los demás. Así, el producto de su trabajo era repartido según sus necesidades y se agrupaban en familias; además, una vez cristianizados y educados, ellos regresaban a sus lugares de origen como catequistas para continuar su misión.

Con buenas obras - decía Quiroga - era como se debería de pacificar a los indios, y así con obras y quehaceres construyó lo que parecía un sueño imposible, algo inalcanzable, etéreo e irrealizable: lograr una "edad dorada", la cual sólo habría existido en épocas tan remotas que se perdían en el tiempo, con personajes más propios de la leyenda que de la realidad. He aquí que la Isla de Utopía o de Ninguna parte, de Tomás Moro, más que la Isla de nunca jamás o Udepotía, de Guillermo Budé, se materializaron con don Vasco en la Hagnópolis por la gran fe de este personaje, y se convirtió en una realidad: "en el pueblo de la inocencia", en los Pueblos de Santa Fe, en ese pequeño país de utopía o "de la eterna felicidad" por la impartición de la justicia.

Para Quiroga, debió ser un rudo golpe el haber fracasado en su intento de crear una ciudad de españoles: primero en la ciudad de Nueva Granada (Tzintzuntzan). Esta ciudad se transformó en una especie de distopía o "del mal lugar", y ello le confirmó su concepto de que muchos de los hombres españoles eran, en realidad, hombres de hierro, hombres rebeldes, injustos y codiciosos, los cuales huían de Pátzcuaro y de Tzintzuntzan a Guayangareo para refugiarse y formar su "ciudadela de hierro", en donde estuvieran solos, lejos de los indígenas; es decir, en un mundo aparte por el simple hecho de no querer estar junto a los naturales. Don Vasco, en cambio, compartirá su felicidad con los hombres blandos como la cera en sus pueblos-hospitales, en los que permaneció por muy largas temporadas, sobre todo en el de México. 
Este libro forma parte del acervo de la Biblioteca Jurídica Virtual del Instituto de Investigaciones Jurídicas de la UNAM

En el "Parecer de don Vasco", terminado de escribir en julio de $1535,{ }^{11}$ y más conocido como Información en derecho, Quiroga decía:

...a estos naturales no se les puede hacer justa guerra, ni toma, sino pacificación e instrucción en la fe y buenas costumbres (y enseñadas éstas) se harían a servicio de Dios y de su Majestad y al provecho de todos y sin perjuicio ni agravio del derecho de estos naturales... porque, si así se pacificasen y persuadiesen, y requiriesen, antes de hacerles guerra, no digo yo el infiel gentil, tan dócil y hecho de cera para todo bien como estos naturales son, pero las piedras duras, con sólo esto se convertirían, sin menester otro golpe de lanza ni espada... éstos naturales no eran, ni son enemigos nuestros, pues no nos molestaban... ni tampoco éstos tales se pueden decir contrarios, ni enemigos del nombre cristiano, sino solamente infieles, que nunca habían tenido noticia del cristianismo y que no merecen, por ser sólo infieles, ser guerreados por fuerza de armas ni violencias, ni de otros malos tratamientos, sino con buenos ejemplos de obras, y persuasiones y predicación de palabras... porque (ellos) de ver esta bondad (en nosotros) se admirasen, y admirándose, creyesen, y creyendo se convirtiesen y edificasen y glorifiquen a nuestro padre celestial... ni siquiera en el Antiguo Testamento, cuando había que tomar con mano armada la tierra de infieles, en ninguna parte leo que se haya declarado la guerra a alguien por el simple hecho de no ser creyente. ${ }^{12}$

Una de las principales comisiones que trajeron los nuevos oidores era la de dividir la Nueva España en provincias, dándoles sus límites y creando nuevos obispados. El papa León X había erigido el 24 de enero de 1519 la famosa Diócesis Carolense en Yucatán, la cual no se materializó y que fue posteriormente "trasladada" por Clemente VII y Carlos V a Tlaxcala - primera diócesis de México - El aragonés fray Julián Garcés fue electo su primer obispo y consagrado en 1527, año en que viajó a tomar

11 Biblioteca Nacional de España, Manuscritos de América, Mss 7369, 155 hojas.

12 Herrejón Peredo, Carlos, op. cit., p. 68. 
Este libro forma parte del acervo de la Biblioteca Jurídica Virtual del Instituto de Investigaciones Jurídicas de la UNAM

posesión de su diócesis; ya muy mayor de edad - tenía cerca de 75 años de edad - fundó su catedral en Tlaxcala en la Iglesia de San Francisco, bajo la advocación de Nuestra Señora de la Asunción. ${ }^{13}$ Poco después, el franciscano fray Juan de Zumárraga es nombrado obispo el 13 de enero de 1528; su sede - la Ciudad de México - y catedral bajo la misma advocación mariana de la de Tlaxcala no había sido consagrado aún y gobernó como obispo electo.

Apremiados por la Corona, los oidores decidieron visitar las provincias de la Nueva España y preparar lo conducente a sus limitaciones, así como conocer la situación real de cada una. Juan de Salmerón fue comisionado a la de Antequera, y don Vasco, a la de Michoacán. El oidor Quiroga realizó la visita a Michoacán en 1533 con varias comisiones: informarse sobre unas minas de cobre; impartir justicia, y fundar la capital de la provincia, lo que hizo en octubre con acuerdo de los españoles y sugirió el nombre de Ciudad de Granada, solicitando el permiso de la Audiencia y del rey. Para entonces ya había fundado el segundo HospitalPueblo de Santa Fe a orillas de la Laguna de Michoacán, que será la última fundación de este tipo de hospitales-pueblos por él realizada. En diciembre de 1533, el Consejo de Indias decide proponer como obispo de la futura diócesis michoacana a fray Luis de Fuensalida.

El 20 de febrero de 1534 se emitió en Toledo una real cédula, en la que se pidió a la Real Audiencia que señalara las demarcaciones de las cuatro provincias y de sus obispados en la Nueva España. Como respuesta, la Audiencia procedió a determinar el 30 de julio de 1535 los límites y distritos de las de México, la Mixteca - Oaxaca-, Michoacán y Coatzacoalcos, puesto que ya existían los obispados de Tlaxcala y México. Se le señalaron veintiséis mojones y al de Michoacán, por su parte, once; además, correspondería a cada obispo poner físicamente los mismos. No

13 AGI, Real Patronato, "Testimonio suscrito de Cristóbal Peregrina de la Bula de erección del Carolense". 
Este libro forma parte del acervo de la Biblioteca Jurídica Virtual del Instituto de Investigaciones Jurídicas de la UNAM

obstante, quedaron pendientes de fijar los límites de las provincias y creación de los obispados de Pánuco y Nueva Galicia.

Al no aceptar Fuensalida el obispado que se le ofreció, el Consejo de Indias propuso a Quiroga el 19 de noviembre de 1535 para ser obispo de Michoacán: "Noble Señor, por la buena relación y concepto que en este Consejo... se tiene de vuestra persona... se ha platicado que convendría que su Majestad os presentase al Obispado de Michoacán...". ${ }^{14}$ Confirmando lo anterior, la reina le dirige una carta desde Madrid el 16 de febrero de 1536, en donde le comenta que "...se os ha presentado a Su Santidad al Obispado... de Mechoacán... teniendo por cierto que por ser cosa aderezada al servicio de Dios Nuestro señor lo aceptareis...". ${ }^{15}$ Después de una nueva y detenida consideración, don Vasco lo aceptó, a pesar de que no tenía orden eclesiástica.

\section{DON VASCO OBISPO}

Simultáneamente a su nombramiento como obispo se realizó en 1536 el obligatorio juicio de residencia a los funcionarios públicos que terminaban su encargo, en este caso a los cuatro oidores de la Segunda Audiencia: Juan de Salmerón, Vasco de Quiroga, Francisco de Ceynos y Alonso Maldonado. El presidente de la misma, el obispo Sebastián Ramírez de Fuenleal, había regresado a España comisionado y fue exento de éste. Salmerón se encontraba en España e hizo el juicio por apoderado; otro tanto lo hará Maldonado, a quien le fue encargado hacer la residencia en Guatemala al adelantado Pedro de Alvarado. ${ }^{16}$

De todas las acusaciones que se le hicieron, varias de ellas referentes al Hospital de Santa Fe de México (fundado - como

\footnotetext{
14 AGI, fusticia, legajo 140.
}

15 Idem.

16 Tenemos ya en prensa y completo con el título de Don Vasco, el oidor (486 pp.) este juicio de residencia, y no en pequeñas partes como se ha publicado, las cuales no permiten conocer el importante quehacer colegiado de los oidores, entre los que sobresale por méritos propios el licenciado Quiroga. 
Este libro forma parte del acervo de la Biblioteca Jurídica Virtual del Instituto de Investigaciones Jurídicas de la UNAM

se ha dicho- hacia septiembre de 1532), don Vasco logró probar que eran falsas y salió bien librado. Don Vasco no pudo tomar posesión de su obispado por varias circunstancias, a pesar del mandamiento de la reina de que lo hiciera de inmediato, siendo una de ellas que por no ser eclesiástico debería ser ordenado sacerdote y tener todas las sagradas órdenes necesarias, que debió obtener entre 1536 y 1538; ya a finales de ese año fue consagrado obispo por Zumárraga. Por otra parte, don Vasco siguió siendo oidor hasta la llegada de su suplente, el licenciado Lorenzo de Tejada, quien le relevó hasta el 24 de julio de 1538; además, no era impedimento ser oidor y obispo. La que sí fue determinante y desconcentraría de las cosas concernientes a su nuevo ministerio es la difícil comisión que el 30 de noviembre de 1537 le hizo el recién nombrado virrey, don Antonio de Mendoza: ${ }^{17}$ la cuenta de los 23,000 vasallos de Hernán Cortés, añejo asunto que no tenía fin por las argucias del conquistador.

...Por la presente os cometo que luego os partáis y vayáis a contar y contéis al Marqués del Valle don Hernando Cortés los veintitrés mil vasallos que él ha de haber y tener por virtud de merced que su Majestad le tiene hecha de ellos, guardando en el contar de ellos las Instrucciones que sobre ello por su Majestad están dadas... ${ }^{18}$

Este asunto, que tenía muchos años sin resolverse y que era más que conocido por don Vasco, le entretuvo por mucho tiempo, hasta que se le dejó concentrar en lo de su obispado.

Una de sus principales preocupaciones desde el principio de su nombramiento fue establecer la sede episcopal y cabecera de la provincia en un lugar adecuado tanto para los españoles como para los naturales; en este sentido, quedaba descartada la Ciudad

17 Antonio de Mendoza fue nombrado virrey de la Nueva España el 17 de abril de 1535 y tomó posesión de su cargo el 14 de noviembre de ese año en la Ciudad de México. Este virrey deseaba aprovechar al máximo la larga y positiva experiencia de Quiroga en el conocimiento y solución de los negocios novohispanos.

18 AGI, Real Patronato, 16, núm. 2, R. 44. 
Este libro forma parte del acervo de la Biblioteca Jurídica Virtual del Instituto de Investigaciones Jurídicas de la UNAM

de Michoacán en Tzintzuntzan (fundada con el nombre provisional de Granada — como ya se ha visto - hacia octubre de 1533), pues ésta había sido ya repudiada por la mayoría de sus pobladores a través de una petición hecha a la Audiencia, en la cual se pedía se tuviera por no fundada por los muchos inconvenientes que tenía. ${ }^{19}$ Resulta irónico que en tanto los "pobladores" de la Ciudad de Michoacán pugnaban por que no se aprobara dicha fundación, ese mismo mes y año (28 de septiembre) el rey firmara en Palencia la cédula por la que se aprobaba el nombre de "Ciudad de Michuacán, y que goce de las preeminencias, prerrogativas e inmunidades que pude y debe gozar por ser Ciudad...".

Ya entregado el cargo de oidor, el obispo electo se trasladó de inmediato a la Ciudad de Michoacán-Tzintzuntzan para tomar posesión de su obispado, lo que ocurrió el 6 de agosto de 1538. Don Vasco aclaró al tomar posesión que lo hacía ahí de manera provisional tanto por lo inapropiado del terreno para la construcción de la catedral como por otras circunstancias que detalló. Al día siguiente (7 de agosto) tomó posesión definitiva en Pátzcuaro:

[y] fue metido en la posesión del sitio, donde en el dicho sitio de Pásquaro está señalado que se ha de fundar y trasladar la dicha iglesia catedral y se han de edificar Casas, Palacio y Audiencia Episcopal del dicho Obispado, como está comenzado a hacer y edificar juntamente con la dicha iglesia catedral, so la invocación de San Salvador, que es todo lo uno y lo otro en la dicha Ciudad de Mechuacán y Barrio de Pásquaro... en la parte y lugar donde solían ser el asiento y Ciudad principal de los dichos naturales y la cabeza de la dicha Provincia de Mechuacán... ${ }^{20}$

Para tomar posesión de dicho lugar se estaban desmontando los antiguos cúes mayores o yácatas, los cuales ocupaban un privilegiado lugar y en donde los antiguos dioses les habían comu-

19 El 3 de septiembre de 1534 se realizó en la Ciudad de México una "Información” para probar que la ciudad de Granada - fundada en Michoacánno era adecuada debido a su mal sitio y por sacar de la Ciudad de México a sus pobladores, desprotegiéndola, y que estaba prácticamente despoblada.

20 AGI, fusticia, L 173-1-2. 
Este libro forma parte del acervo de la Biblioteca Jurídica Virtual del Instituto de Investigaciones Jurídicas de la UNAM

nicado a sus antepasados que ahí sería el lugar prometido por los dioses, o sea, ¡Pátzcuaro!:

...Y fueron a aquel lugar donde ha de ser la iglesia catedral y hallaron ahí los dichos peñascos llamados Petazequa, que quiere decir asiento de $\mathrm{Cu}$... y dijeron ¡Ciertamente aquí es... aquí se llama ¡Pázquaro!... y decía el Cazonzi pasado que en este lugar y no en otro ninguno estaba la puerta del cielo por donde descendían y subían sus dioses...21

Éste fue el espacio escogido por don Vasco para construir su magna catedral, bajo la advocación de San Salvador, evitando así la de San Francisco, la cual era la de Tzintzuntzan, y su confusión con la iglesia de tal nombre en Pátzcuaro.

Su decisión no fue atropellada, pues debió meditarla profundamente tanto por el lugar de la sede como por la construcción de su catedral y forma de ella, y consensuarlo con los pobladores y el virrey, como en efecto lo hizo. Unas de las principales cuestiones a resolver eran que el lugar gozara de agua suficiente; que fuera sano; que comprendiera un amplio espacio; que tuviera madera y piedra para las casas, así como terrenos para sembrar, y que hubiera a su alrededor una gran población de naturales, a los cuales no se les afectara. Todo esto lo encontró en Pátzcuaro, que además tenía la ventaja de ser considerado como "Barrio" de la Ciudad de Michoacán-Tzintzuntzan, y por ello no cambiaría de jurisdicción. Asimismo, don Vasco pensó que la población de españoles sería el cercano lugar de Chapultepec, un espacio llano, con agua y tierras adecuadas a sus necesidades. Antes de ello, don Vasco recabó una amplia información sobre los inconvenientes que tenía Tzintzuntzan para ser asiento de la ciudad episcopal e iglesia catedral y las bondades de Pátzcuaro. ${ }^{22}$

21 Escobar Olmedo, Armando M., Relación de Michoacán, ed. facsímil, Madrid, Testimonio-Ayuntamiento de Morelia, 2001, folio 72v.

22 AGI, fusticia, L 173-1-2. El 9 de septiembre de 1539 se realizó la información ante el alcalde mayor Gonzalo Gómez y el escribano Francisco Troche. 
Este libro forma parte del acervo de la Biblioteca Jurídica Virtual del Instituto de Investigaciones Jurídicas de la UNAM

Importa mencionar que el lugar preciso donde construiría la gran catedral no sería sólo un espacio simbólico, sino también lo suficientemente amplio y sólido para sostener la dicha catedral pensada. Es lógico deducir que para ello se aconsejó de un amplio equipo de expertos constructores tarascos, pues ciertamente ellos tenían amplios conocimientos en el ramo, baste recordar la construcción de las enormes yácatas y el tener que darles el continuo mantenimiento; sin embargo, no había la experiencia en la edificación de ese tipo de iglesias. La cuestión no era menor, ya que debería de edificarse una catedral con planta inusual (de cinco naves), por lo que el terreno tenía que ser lo suficientemente sólido para sostenerla con firmeza, con el agravante de estar en una zona sísmica. En efecto, don Vasco necesitaba topógrafos, geómetras e "ingenieros" versados en el conocimiento del suelo y subsuelo para su gran construcción, así como un amplio equipo de oficiales pedreros, cesteros, albañiles, carpinteros, etcétera, dirigidos por un ágil director de obras y un numeroso cuerpo de trabajadores, contando con los instrumentos necesarios.

Así pues, don Vasco estaba consciente de que se trazaría una nueva ciudad sobre lo que fue el antiguo Pátzcuaro, conteniendo todas las edificaciones propias de una ciudad sede episcopal, además de la catedral provisional, el Colegio de San Nicolás, el hospital y casas para el obispo y su cabildo y de todos los pobladores, construyéndola a tono del nuevo estatus social, pero en un orden ya establecido por don Vasco; por ello, la traza de la ciudad estuvo de acuerdo a las dos capitalidades que representaba.

Los antiguos barrios permanecieron, mas no como ahora se conocen, es decir, ya integrados en la misma ciudad, sino como pueblos cercanos a ella, pues así era la disposición urbana antigua, la cual Quiroga respetó, pero la fundió con la nueva necesidad cultural. Don Vasco permitió que esta antigua estructura urbana prehispánica se entrelazara con la nueva hispana. Él pudo haber cambiado la sede a algún espacio, ya que tenía las facultades para hacerlo; sin embargo, no lo hizo y quiso que ambos elementos permanecieran. La construcción de la catedral se comenzó desde 1538, tal y como lo confirma el apoderado de don Vasco, 
Este libro forma parte del acervo de la Biblioteca Jurídica Virtual del Instituto de Investigaciones Jurídicas de la UNAM

pero aún sin consagrar en un escrito del 5 de septiembre de ese año, en el que dice que inicia la obra de la Iglesia de San Salvador.

La cuestión se complicó cuando en 1540-1541 el virrey Mendoza decidió ir personalmente a la pacificación de los teúles-chichimecas, quienes se rebelaron por los grandes males que Nuño de Guzmán y su gente les habían hecho. Mendoza conoció el espacio sugerido por don Vasco y lo aceptó, de ello hay constancia; sin embargo, pronto cambiará de opinión a causa de la presión de los encomenderos, quienes no aceptaban el lugar elegido por don Vasco y se habían pasado al de Guayangareo, en donde se daban todas las condiciones que sólo para ellos eran necesarias, siendo una de ellas la que más importaba: que no hubiera cerca tantos naturales, pues estaban temerosos de que los pudieran atacar.

Mendoza, necesitado del apoyo de los encomenderos para la pacificación, aceptó la fundación de Guayangareo como ciudad y tomó el temerario acuerdo de ponerle el nombre de Ciudad de Michoacán, dando su mandamiento para ello el 18 de mayo de 1541. Lo anterior no era posible debido a que desde la expedición de la Bula Erectio et Provisio Eclesiae Michocacanensis - Erección del obispado michoacano - el 8 de agosto de 1536, fecha dada por el mismo don Vasco, ${ }^{23}$ eleva al rango de ciudad la sede episcopal, pues de otra manera no podría estar sin esa categoría. Es más, cuando se decidió su cambio a Pátzcuaro, se pidió se solicitara al papa un "breve" para ello, a lo que el rey contestó que no era necesario, ya que él podría cambiar a un barrio, máxime que era en la misma ciudad; a pesar de ello, tiempo después se emitió un breve del papa Julio III confirmando el cambio.

El gran obstáculo para que don Vasco lograra terminar de construir su magna catedral se debió fundamentalmente a la continuada oposición de los pobladores de la Ciudad de MichoacánGuayangareo, quienes exigían al obispo que pasara la iglesia catedral a esta ciudad; además, denunciaban que dicha iglesia en Pátzcuaro era muy grande, costosa y en detrimento de los naturales.

23 AGI, fusticia, legajo 140. 
Este libro forma parte del acervo de la Biblioteca Jurídica Virtual del Instituto de Investigaciones Jurídicas de la UNAM

Ya para entonces don Vasco había logrado varias cédulas y mandamientos a favor de la construcción de su iglesia y los fondos necesarios para ello. Los costos se dividían en tres partes: los encomenderos, la Corona y el obispado mismo, además de que se le debería de entregar lo recaudado por el obispado de México, el que se hacía cargo del de Michoacán en tanto hubiera obispo, una vez descontados los gastos realizados y comprobados.

Este último asunto y la cuestión del pago de diezmos y de los límites entre ambos obispados ocasionaron un largo y sonado proceso, que junto con otros ${ }^{24}$ hicieron que Quiroga pasara a España al Real Consejo de Indias para aprontar la solución de esos casos. El 26 de abril Mendoza le autoriza a don Vasco llevar a España, entre otros, a don Francisco (indio) como procurador de los naturales de Michoacán y a don Antonio (hijo del cazonci); en junio se encuentra aún en San Juan de Ulúa esperando zarpar en la flota a España, y deja como gobernador del obispado a fray Alonso de la Veracruz. El barco en el que iban se estropeó y tuvo que regresar, y don Vasco retomó su gobierno; no obstante, la construcción de la catedral seguía, aunque ignoramos quién era el maestro mayor, ya que Hernando Toribio de Alcaraz se hará cargo de la obra hacia 1544, y él en la declaración que hizo en 1560, a petición del comisionado del virrey Velasco, para revisar la obra de la iglesia catedral dice: “...yo le allané en lo así en lo por mí edificado, como en lo antiguo hecho antes de que yo viniese...". ${ }^{25}$

\section{LA GATEDRAL PERDIDA DE DON VASCO}

La construcción y traza catedralicia causó pronto revuelo por su tamaño y forma, de tal manera que la Corona pidió al visitador de la Nueva España, el licenciado Francisco Tello de Sandoval, que “...informase del sitio y asiento de la Ciudad Nueva de Michoacán

24 Otros procesos fueron los de Juan Infante, que intentaba apoderarse fraudulentamente de varios pueblos de la Laguna de Michoacán, y el de la fundación de la Ciudad de Michoacán en Guayangareo.

25 AGI, Audiencia de México, legajo 374. 
Este libro forma parte del acervo de la Biblioteca Jurídica Virtual del Instituto de Investigaciones Jurídicas de la UNAM

[Guayangareo y también se]... informase de la iglesia que el obispo manda hace en Páscaro y de la traza y calidad de ella.....${ }^{26} \mathrm{El}$ licenciado Tello, a causa de sus varias comisiones y ocupaciones, se encontraba imposibilitado para hacerlo personalmente, por lo cual nombró el 6 de marzo de 1545 al alcalde de Nueva Galicia, Baltasar Gallegos, para que fuera a ambas ciudades e informara de ellas y las viera; a su vez, le pidió que le avisara si la iglesia que se construía era "cómoda y conveniente" para la catedral, conforme solían ser las otras catedrales.

Gallegos se apersonó en la Ciudad de Michoacán-Guayangareo; la visitó e hizo la información sobre lo pedido con catorce testigos, entre ellos varios de los encomenderos y opositores a la obra de don Vasco en Pátzcuaro. Todos los que la conocían coincidieron en que era una traza nunca vista; incluso, algunos declaran haber visto los cimientos y estaban de acuerdo que sería una obra buena para indios, pero no para españoles, ya que era un lugar húmedo y enfermo. Destaca entre ellos la declaración del maestro de geometría Juan Ponce, quien dijo que ya le habían llevado como maestre a que la viera, y le parecía la traza de ella como algo nunca visto, pero que la comprendía por ser el propósito de que cupiera mucha gente y vieran todos la misa, que era el intento de la forma lo que le parece bien. Por otra parte, Ponce hizo algunas críticas, como que los cimientos no llevaran cal, sino barro y piedra, y que a pesar de avisarle de ello, el obispo "no quería tomar consejo con ningún oficial y por eso la obra iba muy gruesa y grosa (pesada)".

La obra continuó lentamente en su construcción, pero en 1548 don Vasco decidió nuevamente pasar a España para aprontar los procesos ya mencionados y agilizar otros nuevos que se le acumulaban; en ese viaje llevó consigo al maestro de la obra, Hernando de Alcaraz, dejando comisionados para que la continuaran. En Pátzcuaro y su región había gran inquietud por lo

26 AGI, fusticia, legajo 155-2, "La Ciudad de Mechuacán e indios de su Provincia, con(tra) el Obispo de dicha Ciudad, sobre la obra y edificio de la Catedral de dicha Ciudad". 
Este libro forma parte del acervo de la Biblioteca Jurídica Virtual del Instituto de Investigaciones Jurídicas de la UNAM

riesgoso del viaje y su avanzada edad. Gran alegría fue cuando el 6 de enero de 1549 llegó una carta de don Vasco avisando que había llegado con bien a España; al recibirla, el provisor Juan Zurnero le contestó y dio interesantes datos, entre otros sobre la construcción catedralicia. Le informó que en cuanto se supo su feliz arribo, el siguiente domingo se había hecho una muy solemne procesión a la iglesia de

...San Salvador y allí se dio la misa mayor y díjola el Provincial de los franciscanos (Fray Toribio Motolinía), y fray Jacobo (Daciano) y fray Juan de Badia se vistieron con él al altar y había otros cinco frailes, de manera que se hizo con mucha solemnidad. Llegáronse tantos indios con el regocijo de la buena nueva y era tanta la gente, que el Provincial se maravilló mucho diciendo que le parecía - antes que lo viese - que en toda la Provincia no hubiera más gente; y conoció bien la justa y Santa razón y causa que a Vuestra Señoría le habia movido hacer la iglesia de la traza que lleva y lo mismo les pareció a dos frailes que venian con él, que nunca habian estado en la Provincia, y murmuraban de los religiosos y de los demás que había estorbado o estorbaban tan santa obra. El provincial es un fray... que los indios llaman Motolinea, holgóse tanto de la cristiandad y buena orden de ella que halló en el Obispado de Vuestra Señoría, que iba dando gracias a Nuestro Señor diciendo que en toda la Nueva España entre los naturales no había la mitad de la cristiandad ni de tres partes, una como en la Provincia de Mechuacán y llevaba gran voluntad de lo comunicar con el señor Visorrey... ${ }^{27}$

Como se aprecia, la obra de la iglesia avanzaba y lograba sus objetivos de reunir mucha gente en lo entonces construido; poco después, el arcediano Lorenzo Álvarez le avisa al obispo que las carretas traían cada día un camino de piedra y los canteros estaban sacando piedra, y que ya cuando regresara Alcaraz encontraría recaudo. Alcaraz regresó en 1552 para continuar sus trabajos.

Si bien la estancia de don Vasco fue larga, también lo fue provechosa, pues logró que se fallara a su favor lo referente a los límites, los diezmos y los adeudos que le tenía el obispado de

27 AGI, fusticia, legajo 173-1-2. Las cursivas son nuestras. 
Este libro forma parte del acervo de la Biblioteca Jurídica Virtual del Instituto de Investigaciones Jurídicas de la UNAM

México; ${ }^{28}$ se dieron instrucciones al virrey para terminar la construcción de su Catedral; ${ }^{29}$ también se le confirmó a la Ciudad de Michoacán-Pátzcuaro como sede episcopal tanto por un breve de Julio III en 1550 como por una real cédula del 20 de octubre de 1552, además de que en ésta se ordenaba a los de Guayangareo que no le usurparan el nombre de Ciudad de Michoacán, y a los que se quedaren en aquella a vivir lo podían hacer, pero llamándose "Pueblo de Guayangareo".

Todo esto fue sin duda un duro golpe a los opositores de don Vasco, quienes redoblarán sus esfuerzos en estorbar a toda costa la obra catedralicia. En efecto, apenas regresó don Vasco en 1554 con el nuevo arzobispo, el dominico fray Alonso de Montúfar, y preparándose para asistir al primer concilio mexicano, el virrey mandó a los de la provincia de Michoacán a que apoyaran la construcción de San Salvador en los términos mandados por la Corona.

Las quejas de los encomenderos no tardaron en llegar, aduciendo que de hacer lo ordenado se ocasionarían graves perjuicios en los naturales, además de lo extremadamente costoso y suntuoso de la obra. Para apoyar sus protestas, aquéllos presionaron a los gobernadores de sus pueblos encomendados y otros para que se quejaran de Quiroga y la construcción. La táctica surtió efecto en el virrey Velasco, y él mismo se apersonó el 6 de diciembre de 1555 a inspeccionar la obra, acompañado de dos expertos: el maestro de cantería, García de la Fuente, y el maestro de carpintería, Alonso Luzero, a los cuales se unió el maestro de la obra, Toribio de Alcaraz. Después de revisarla con todo detenimiento, los expertos acordaron que lo grueso de los muros

28 La sede estaba vacante por la muerte del arzobispo fray Juan de Zumárraga ocurrida el 3 de junio de 1548, cuando don Vasco estaba ya de camino a España. Había fuertes rumores de que se elegiría a Quiroga como nuevo arzobispo.

29 AGI, fusticia, legajo 155-2, Valladolid, 11 de marzo de 1550: “...que deis orden que la tercia parte se pague de nuestra Real Hacienda, y con la otra tercia parte, ayuden los indios del dicho Obispado, y con la otra tercia parte los vecinos y moradores, comenderos que tienen pueblos encomendados en él...". 
Este libro forma parte del acervo de la Biblioteca Jurídica Virtual del Instituto de Investigaciones Jurídicas de la UNAM

de las cinco naves de la iglesia tenían suficiente fortaleza y se podrían cubrir de madera “....sin sospecha alguna...". Por lo que se refería a la capilla mayor, que era la cabeza de todas las naves, ellos declararon que se podría cerrar de piedra de cantería, ya que estaba hecha con sobrada fortaleza. Por último, ellos manifestaron que la torre que se construía debía hacerse de cantería y con bóveda, “...pues no se compadece de otra manera...".

Ese mismo día tanto el señor virrey como el señor obispo don Vasco de Quiroga, habiendo visto el parecer que dieron los expertos, acordaron que la obra de la iglesia se continuara y terminara, con la aclaración de que la obra fuera llana y sin talla ni imaginería para no hacerla costosa. Posteriormente, se hicieron algunas otras observaciones, ya que Velasco escribió en mayo del año siguiente al rey y le informó que la obra llevaba malos cimientos, que la capilla mayor tenía cien pies de hueco en cuadro ${ }^{30}$ y se le quitaron cuarenta, y que se moderó la obra, puesto que "...para los naturales no era necesario obra tan grande ni suntuosa. Quité de la costa que la iglesia llevaba... más de sesenta mil castellanos... demás de la gran vejación que redimen los naturales...". ${ }^{31}$

Un dato de gran importancia que proporciona el virrey en su carta son las medidas internas de la iglesia: la nave mayor mide 60 pies de hueco (16.68 m) y 120 pies de largo (33.36 m); las otras dos - las transversales - , 45 pies (12.51 m), y las oblicuas, 40 pies (11.12 m), aclarando que de largo las cinco naves tenían 120 pies (33.36 m). La capilla mayor, en la que confluían las diez paredes de las cinco naves, su bóveda tendría solamente cien pies de hueco en cuadro $(27.80 \mathrm{~m})$, ya que se le quitaron cuarenta pies (11.12 m), y ésta sí podría cubrirse de cantería. Llama la atención la preocupación del virrey por las presuntas vejaciones que se harían a los naturales.

La obra continuó con largas interrupciones, y en 1560 nuevamente se presentó una, debido a las continuas quejas de los encomenderos y en seguimiento del juicio contra don Vasco em-

\footnotetext{
30 El pie castellano medía aproximadamente $0.278 \mathrm{~cm}$.

31 Archivo de los Duques del Infantado, libro X.
} 
Este libro forma parte del acervo de la Biblioteca Jurídica Virtual del Instituto de Investigaciones Jurídicas de la UNAM

prendido por ellos y por los gobernadores de varios pueblos de la provincia michoacana, quienes alegaban perjuicios y vejaciones por tener que enviar indios de servicio a la citada obra. El virrey, ${ }^{32}$ quien se encontraba molesto, envió al maestro de cantería Claudio de Arziniega a que visitara la obra y revisara si se cumplían los acuerdos y lineamientos acordados. Es importante aclarar que en el transcurso del mencionado juicio, los gobernadores que habían denunciado los agravios por la obra fueron ante don Vasco y le dijeron que habían sido los encomenderos quienes los habían presionado a esa denuncia, y que ellos y los naturales, por su propia voluntad, sí estaban dispuestos a colaborar con la misma. Luego, la confesión fue realizada ante notario.

La visita de Arziniega (abril de 1560) para revisar la catedral fue muy accidentada; no obstante, cabe señalar que él era el favorito del virrey para realizar varias obras y que será, posteriormente, famoso por sus fuertes críticas a las catedrales de Michoacán, Puebla y México, siendo más adelante el maestro de la segunda y de esta última con grandes errores, los cuales debieron ser costosamente corregidos. No es posible seguir en detalle lo acontecido y nos centraremos en los aspectos fundamentales. Arziniega venía sólo comisionado a revisar la obra e informar al virrey, pero dicha comisión no le fue comunicada a don Vasco, y al inspeccionar la obra, aquél dio órdenes precisas sobre ella, para lo que no estaba facultado.

Así pues, Arziniega declara, entre otras cosas, que los cimientos, las paredes y los estribos son obra falsa, porque tienen ruines fundamentos, pues están sobre tierra muerta; las calas hechas a los cimientos indican que no llevan cal y se han convertido en tierra y están tronados y huecos; las paredes donde se juntan los estribos están rotas y mal labradas, y para tapar el desperfecto se han cubierto con barro; asimismo, los estribos se encuentran tan mal hechos que no podrán soportar la obra, y de seguirse así se vendría abajo todo.

32 AGI, fusticia, legajo 155-2. 
Este libro forma parte del acervo de la Biblioteca Jurídica Virtual del Instituto de Investigaciones Jurídicas de la UNAM

A continuación Arziniega da varias instrucciones precisas (son veinticinco), que al realizarlas permitirán que la obra "quede segura y graciosa y conforme a razón"; sin embargo, a dichas instrucciones Hernando Toribio hizo veinte contradicciones. Así, Hernando Toribio recuerda que la obra ya ha sido inspeccionada por expertos en otras dos ocasiones y han sido favorables, incluso la última fue hecha por el mismo virrey, quien supo de la fortaleza de los cimientos, las paredes y la obra en general. Cuando Arziniega habla de que la obra está sobre tierra muerta, eso es falso - argumenta Hernando Toribio-, ya que se encuentra cerca la roca y la peña, y que si hubiere algún otro defecto, éste será menor y reparable y no el caso de incluso derribar los estribos — son más de cincuenta-, pues lo que pide Arziniega es prácticamente derribar toda la obra y hacerla de nuevo, lo cual además sería en grave perjuicio para la Real Hacienda. Por otra parte, el modificar la nave mayor como Arziniega pide (sin su cabeza que es la capilla) no convendría, puesto que quedaría cuerpo sin cabeza, cabrían pocos y la nave sería muy corta. Hernando Toribio termina diciendo que el parecer de Arziniega es inconsiderado y arrebatado.

Posteriormente, se siguió proceso por parte del obispo contra el parecer de Arziniega y la notificación hecha a Toribio para que "...desde hoy dicho día (dos de mayo) cese la obra que se hace en la dicha iglesia y no se prosiga más...”. La Real Audiencia lo conoció, y después de seguirlo, ésta acordó en febrero de 1561 remitirlo al Real Consejo para que cada quien siguiera su derecho.

Volvamos a la descripción de la traza de la catedral, en la que a lo largo del interior de las cinco naves se hallaban distribuidos cincuenta estribos, la mayoría de los cuales estaban esviejados, es decir, eran oblicuos, ya que don Vasco no deseaba que estorbaran la vista al altar mayor y para evitar la costumbre de los naturales de ponerse detrás de ellos. Este esviaje se nota claramente en el diseño del escudo del humilladero, pero no en el del escudo pintado, donde se ven los estribos cuadrados como lo pide Arziniega. En cada nave habría cinco espacios de cada lado entre los estribos, que después serán cerrados con arcos por petición de Arziniega. 
Este libro forma parte del acervo de la Biblioteca Jurídica Virtual del Instituto de Investigaciones Jurídicas de la UNAM

El espacio resultante entre las naves formaría cuatro triángulos arbolados, una especie de huertas o jardines cuya entrada no era por el exterior, sino por unas puertas colocadas a ambos lados del final de las naves oblicuas. Cada nave tenía su propia entrada, pero la de la principal tenía adosado un espacio cuadrado y aportalado en forma de torre, cuyas medidas eran de diez pies por lado, sin contar el ancho de los muros. Esta construcción no permitía ver la puerta principal, pues estaba resguardada por la torre frontal que, a su vez, tenía su portada. Afuera de los muros de esta nave tenía a sus lados dos campanarios con sus caracoles, que fueron muy celebrados por lo curioso de su hechura. Toda la iglesia se encontraba circundada por un muro perimetral, el cual evitaría que se entrara a las partes triangulares arboladas; si este muro fuera un cimiento perimetral, ello daría una enorme solidez a toda la construcción.

A espaldas del altar mayor o de los reyes se habían comenzado a construir otros dos caracoles cercanos, que no se ven en el diseño primitivo, y tal vez sirvieran para subir a los andenes para servicio de las ventanas y otros menesteres.

\section{HALLAZGOS ARQUEOLÓGICOS VISUALES Y CON GEO-RADAR}

\section{Resultados}

Para saber lo referente al proyecto y construcción de la catedral, nos basamos en las fuentes documentales directas, principalmente, del Archivo General de Indias, y para conocer lo que pudo quedar de lo que se realizó, solicitamos a la reconocida empresa Vico $^{33} \operatorname{los}$ rastreos necesarios con Geo-radar, a fin de estar en posibilidad de tener la noticia directa de lo que fue el tamaño del magno edificio de don Vasco.

33 Constructores y Asesores Vico, S. A. de C. V. Agradecemos a los ingenieros Salvador Delgado y su hijo Hassael Delgado, quienes nos apoyaron con gran entusiasmo. 
Este libro forma parte del acervo de la Biblioteca Jurídica Virtual del Instituto de Investigaciones Jurídicas de la UNAM

Para tratar de descubrir los restos de la Iglesia, decidimos realizar dos acciones: una visual e iniciar una prospección en la parte sur del atrio, a la que continuarán otras hasta cubrir, en lo posible, todo el perímetro de la Iglesia. Se efectuaron nueve "barridos" que cubrieron prácticamente la totalidad del atrio: desde el portal de ingreso a las oficinas de la Basílica hasta la pared del atrio por el poniente.

Los resultados de esta búsqueda arrojaron interesantes descubrimientos, pero por ahora nos concentraremos solamente en los siguientes: se localizó la cimentación de la nave oblicua ${ }^{34} \mathrm{co}-$ lindante a la proyectada área triangular ajardinada, dando un ancho promedio de 3 metros y de largo 32 metros. Con este dato podemos ir deduciendo la situación del resto de las naves, lo que se comprobará con las siguientes prospecciones. Adelantamos que también se localizaron los muros de la parte adosada a la entrada principal y muro perimetral.

Para conocer realmente el tamaño de las cinco naves diseñadas por don Vasco, pero sin la necesidad de realizar ninguna cala, ya que obviamente se requerirían permisos especiales y que en manera alguna podríamos ni deberíamos hacer, decidimos recurrir a la compañía Vico, quien es poseedora de un Geo-radar. Este instrumento, que funciona a través de la propagación de ondas electromagnéticas, localiza las variaciones en la estructura del suelo cuando hay diferencias en la constante dieléctrica del terreno, y permite hacer prospecciones rápidas y efectivas sin ninguna afectación para el terreno estudiado. De esta manera, se permite detectar los elementos que pudieran estar contenidos en dicha estructura.

\section{CONCLUSIONES}

Utilizar tan alta tecnología nos significaba un método adecuado y efectivo para la localización de la traza de las cinco naves y sus

34 Ya otros investigadores habían localizado partes de esta estructura. 
Este libro forma parte del acervo de la Biblioteca Jurídica Virtual del Instituto de Investigaciones Jurídicas de la UNAM

cimientos, que aún pudieran ser detectados sin ningún daño al espacio en donde se encontraba la citada catedral y que ahora ocupa la Basílica de Nuestra Señora de la Salud. No nos ha movido para ello conocer, como simple curiosidad, la forma y tamaño de la catedral, sino el utilizar tanto las fuentes documentales del siglo XVI y la observación directa como la arqueología urbana, por medio de la novedosa tecnología de la prospección Geo-radar y radar con magnetómetro, con lo cual hemos podido rescatar valiosos testimonios de la obra por excelencia de don Vasco.

Todo ello nos permite ahora revalorar y difundir el decidido esfuerzo de tan excepcional humanista en estos campos, y reflexionar que "la locura" del abulense don Vasco de Quiroga y su afán innovador tenían simplemente una auténtica visión y acción de servicio a la sociedad en formación, primando la atención en los pueblos originarios; además, nos da la posibilidad de poder corroborar que sin quererlo su obra se habría convertido en "la octava maravilla", que subyace perdida en su inolvidable Ciudad de Michoacán-Pátzcuaro, y que de rescatarse lo que de ella ha quedado servirá de merecido homenaje a tan ilustre humanista.

Damos al final de este trabajo la información de algunos de estos hallazgos sobre la famosa catedral "perdida" de don Vasco; a su vez, deseamos con este aporte difundir una pequeña parte del extraordinario quehacer del ilustre madrigalense en este 450 aniversario de su fallecimiento.

Lo hemos mencionado ya en otras ocasiones por escrito. El doctor José Luis Soberanes dijo lo siguiente en el prólogo a la edición quiroguiana de Aguayo Spencer:

...Dentro de esa vorágine humana que fue la penetración europea en América (y no me refiero a la española) destaca la persona de don Vasco de Quiroga, quizá la figura más noble, buena y entrañable del siglo XVI mexicano. Sinceramente creo que la posteridad no le ha hecho justicia a tan limpio personaje de nuestra historia - y se preguntaba Soberanes - ¿qué importancia encierra publicar documentos de Vasco de Quiroga? - y se contestabaPienso que enorme, si queremos conocer el pensamiento de un 
Este libro forma parte del acervo de la Biblioteca Jurídica Virtual del Instituto de Investigaciones Jurídicas de la UNAM

intelectual como lo fue don Vasco, necesariamente debemos estudiar sus escritos... [Por último] — dijo Soberanes - quiero señalar que en mi modesta opinión, México tiene todavía una deuda de gratitud para con aquel gran señor que fue Tata Vasco...

La obra de don Vasco, en sus diferentes áreas de trabajo, fue tan importante que a través de los siglos permanece su presencia, ya sea en su Colegio de San Nicolás, en Santa Fe de la Laguna, o bien en el trozo que quedó de su gran catedral - actual basílica-, y particularmente en Pátzcuaro y su entorno, así como en diversas partes de Michoacán, ya que donde se escuche su nombre se relaciona de inmediato como un sinónimo de gran benefactor. Ello explica por qué los patzcuarenses - orgullos de ese legado - sean tan celosos de todo cambio, en el que sin duda está presente - directa o indirectamente - el respeto a la memoria de su gran "tata", quien aparte de haber sido un gran educador y celoso eclesiástico, tuvo la visión de un gran urbanista, el cual nos ha dejado una extraordinaria ciudad que es fiel reflejo de su idea llamada "Pátzcuaro", además de que puso los fundamentos de la michoacanidad.

\section{Fuentes DE GONSUltA}

\section{Bibliografia}

Chanfón Olmos, Carlos, La Catedral de San Salvador. El gran proyecto de don Vasco de Quiroga, México, UNAM, Instituto de Investigaciones Estéticas, 1986.

Escobar Olmedo, Armando M., Relación de Michoacán, ed. facsímil, Madrid, Testimonio-Ayuntamiento de Morelia, 2001.

Guevara, Antonio de, Menosprecio de corte y alabanza de aldea, Buenos Aires, Espasa-Calpe, 1947.

Herrejón Peredo, Carlos, Información en derecho, México, SEP, 1985. 
Este libro forma parte del acervo de la Biblioteca Jurídica Virtual del Instituto de Investigaciones Jurídicas de la UNAM

Información en derecho, biografia e ideario, Morelia, Gobierno del Estado de Michoacán de Ocampo-Universidad Michoacana de San Nicolás de Hidalgo, Centro de Estudios sobre la Cultura Nicolaita.

Moreno, Juan José, Fragmentos de la vida y virtudes del V. Illmo. y Rmo. Sr. Dr. D. Vasco de Quiroga, México, 1766.

Archivos

ARCHIVO DE LOS DUQUeS Del InFANTADO, libro X, "Libro en que se asientan a la letra las cartas que el Virrey (don Luis de Velasco) mi Señor escribía a su Majestad...”.

Archivo General de InDias (AGI), Audiencia de México, legajo 374.

, Justicia, legajo 140.

, Fusticia, legajo 155-2, “La Ciudad de Mechuacán e indios de su Provincia, con(tra) el Obispo de dicha Ciudad, sobre la obra y edificio de la Catedral de dicha Ciudad".

, Fusticia, L 173-1-2.

-, Real Patronato, 16, núm. 2, R. 44.

, Real Patronato, 184, R. 15.

, Real Patronato, "Testimonio suscrito de Cristóbal Peregrina de la Bula de erección del Carolense".

Biblioteca Nacional de España, Manuscritos de América, Mss 7369. 
Este libro forma parte del acervo de la Biblioteca Jurídica Virtual del Instituto de Investigaciones Jurídicas de la UNAM

\title{
VASCO DE QUIROGA Y LA REPERGUSIÓN SOGIAL DE SUS PUEBLOS-HOSPITAL: AYER Y HOY
}

\section{Álvaro LOZANO PlatonOfF*}

\begin{abstract}
SUMARIO: I. Introducción. II. Lectura social del pensamiento de Vasco de Quiroga. III. Repercusión de su pensamiento-labor en sus pueblos. IV. Una dinámica de detonación de los mismos pueblos en nuestros días. V. Gratitud a Quiroga, a modo de conclusión. VI. Bibliografia.
\end{abstract}

\section{INTRODUCGIÓN}

Los hombres se conocen mucho más por lo que hacen que por lo que dicen. Aunque es un hecho que en algunos casos, muy pocos por desgracia, el decir, su escribir y la expresión de su pensamiento tienen la dicha de tener un doble peso: por un lado, el valor de lo ahí manifiesto en el lenguaje, y por otro lado, que todo lo expresado brota y refiere a su propia vida.

Ése es el caso del oidor-obispo que a todos nos reúne aquí. Él es un hombre que antes de escribir unas ordenanzas ya había fundado un par de pueblos; que antes de enviar una Información en derecho ya había "oído", visto y, en definitiva, conocido en primera persona todo lo que en esa obra expresaba, y había comenzado a buscar, invirtiendo en ello gran parte de su vida y hacienda, una solución a lo por él criticado. Ambas cosas - su experiencia de los

* Universidad Católica Lumen Gentium. 
Este libro forma parte del acervo de la Biblioteca Jurídica Virtual del Instituto de Investigaciones Jurídicas de la UNAM

abusos y su experiencia en los pueblos-hospital - fueron el contenido fundamental de esa obra.

No obstante, he de confesar mi muy incipiente amistad con don Vasco de Quiroga. Aunque haya sido un conocido de tiempo atrás, es hasta los últimos dos años que su pensamiento ha resonado más a fondo en mi labor de investigación y de proyección cultural. Mi lectura de Quiroga es desde su labor de humanista: luchador por instaurar una justicia e igualdad que no había, y constructor de pueblos-hospital como camino para realizarlo. Me centraré fundamentalmente en sus pueblos-hospital, en cómo éstos son el concentrado de las inquietudes de su conciencia y los motores de parte importante de su vida. En una primera parte, haremos una lectura social del pensamiento de Vasco de Quiroga, misma que nos servirá de pivote para analizar el reflejo de su pensamiento en la labor llevada a cabo en sus pueblos-hospital. En una segunda parte, realizaremos un comparativo de las condiciones vividas por Quiroga y las que hoy día tenemos, que nos permiten considerar la validez del modelo quiroguiano en nuestros días.

Si estamos hoy aquí reunidos, es porque un hombre fue capaz de dejarnos unos cuantos cientos de páginas escritas y una cantidad innumerable de vestigios de su paso por este país y de algunos pueblos que vivieron bajo la guía de sus ordenanzas al menos hasta el 3 de febrero de 1872, sin negar el influjo que en ellos hoy todavía se respire de su fundador. Lo escrito y lo hecho por él no son cuestiones que contradigan la razón, pero tampoco son obras que sorprendan de ordinario; sin embargo, son cosas que muy pocos han sido capaces de decir y casi ningún otro ha podido realizar. Es intrigante esa cuestión: ¿por qué no hubo más pueblos-hospital?, ¿por qué hoy día no se pueden detonar? Esperemos que estas sencillas líneas nos ayuden a valorar la gran empresa del oidor-obispo, su gran repercusión, pero sobre todo su misteriosa personalidad, que hizo posible lo que muy pocos han podido llevar a cabo. 
Este libro forma parte del acervo de la Biblioteca Jurídica Virtual del Instituto de Investigaciones Jurídicas de la UNAM

\section{LEGTURA SOCIAL DEL PENSAMIENTO DE VASCO DE QUIROGA}

De la elección que S. M. hizo en la persona del licenciado Quiroga para Mechuacán (que le puedo bien llamar dichoso) tengo por cierto y siento con muchos que ha sido una de las acertadas que S. M. ha hecho en estas partes para llevar indios a Paraíso, que creo que S. M. pretende más esto que el oro y plata. Porque crea que el amor visceral que este buen hombre les muestra, el cual prueba bien con las obras y beneficios que de continuo les hace y con tanto ánimo y perseverancia, que nos hace ventaja a los prelados de acá. Y como este sea lo principal en que el Vicario de Cristo fue examinado para se le dar la prelacía y ser la cosa que a estos pobres naturales más atrae a las cosas de nuestra fe y que siendo oidor, gasta cuanto S. M. le manda dar de salario a no tener un real y vender sus vestidos para proveer a las congregaciones cristianas que tiene en dos hospitales: el uno cabesta ciudad y el otro en Mechuacán, haciéndoles casas repartidas en familia a su costa y comprándoles tierras y ovejas con que se puedan sustentar; de creer es que cuando se viere pastor con sus ovejas lo hará harto mejor, aunque no sé otro que le iguale en esta tierra. Y para mi es harta represión y téngolo dicho y por averiguado que nos ha de hacer vergüenza a los obispos dacá, presertim a los frailes. ${ }^{1}$

El fray Juan de Zumárraga destaca al rey de España una serie de atributos del oidor electo obispo, los cuales permiten comprender su pensamiento: llevar al cielo, beneficiar, poder sustentar y vergüenza. Detrás de cada uno de ellos se sintetiza el compromiso social del oidor, sus conflictos que la coherencia le exigían, y la perseverancia que - como se testimonia en sus últimas voluntades y la repercusión de su trabajo - tuvieron estas notas iniciales a lo largo de su vida.

1 Cuevas, Mariano, Documentos inéditos del siglo XVI para la historia de México, 2a. ed., México, Porrúa, 1975, pp. 76 y 77. 
Este libro forma parte del acervo de la Biblioteca Jurídica Virtual del Instituto de Investigaciones Jurídicas de la UNAM

\section{Llevar al cielo}

Basados en el testimonio de Cabrera sobre el llamado vocacional de Quiroga, no podemos olvidar ese compromiso que asume cuando al estar en el convento recogido en oración escucha en el canto de aquéllas la vocación a la que Dios lo llamaba, y decide "verdaderamente que ellas me tocan y me corresponden: bendigo a Dios que es quien me adoctrina... quien me llama al camino, para que bajo su protección me haga a la vela cuanto antes, y, atravesando el vasto océano, pueda ayudar a la conversión de los indios a la fe". 2

La historia de Quiroga y su preocupación por la vida de los indios despierta en él a su llegada a la Nueva España, nuevos dolores y un compromiso mayor. La ridiculización del mensaje evangélico que ocasionaron los primeros diez años de la conquista calaron en la vida de Quiroga, quien no sólo acentuó la degradación en la que se habían hecho vivir, sino también el clamor ante la pérdida de su dignidad y el sinsentido de la vida de aquéllos.

Considerando que la derrota de los hombres no es otra más que la derrota de sus dioses, ${ }^{3}$ Quiroga mantuvo desde el inicio un celo intenso por la fe, buscando imbuir a los indios en la fe y en las buenas costumbres. ${ }^{4}$ Para ello, Quiroga constituye en sus pueblos-hospital una capellanía, la cual tenía como finalidad esencial el acompañar en todo lo espiritual a su pueblo, cuidando de ellos y otorgándoles las bases necesarias en la catequesis y la vida cristiana. ${ }^{5}$ Pero no se reducía la labor de sus pueblos-hospital a la

2 Campos, L., "Métodos misionales y rasgos bibliográficos de don Vasco de Quiroga según Cristóbal Cabrera”, en Varios autores, Don Vasco de Quirogay arzobispado de Morelia, México, JUS, 1965, pp. 109-116.

3 González Cruz, Manuel, Teología de la misericordia, implícita en los escritos y en la praxis de Vasco de Quiroga, México, Universidad Pontificia de México, 2012, p. 88.

4 Quiroga, Vasco de, Información en derecho, México, 1985, p. 11. De ahora en adelante esta obra se citará como Información, seguida del número de página.

5 Tena Ramírez, Felipe, Vasco de Quiroga y sus pueblos de Santa Fe en los siglos XVIII y XIX, México, Porrúa, 1990, p. 101. 
Este libro forma parte del acervo de la Biblioteca Jurídica Virtual del Instituto de Investigaciones Jurídicas de la UNAM

dinámica de conservación de la fe, sino de una vivencia de la fe a la imagen de las primeras comunidades, en las que unidos en la oración lo compartían todo. ${ }^{6}$

\section{Beneficiar}

La defensa de los indios se convierte para el oidor en un compromiso personal que supera con creces sus grandes trabajos que le correspondían como oficio. La finalidad de la Información en derecho era justamente otorgar uno de los fundamentales beneficios que todos han de poseer: la verdad. La nueva instrucción era para el oidor, a todas luces, injusta para con los indígenas por parte de los controladores del pueblo, de ahí que se da a la tarea de hacer notarlo y ofrecer la Información en derecho, ${ }^{7}$ es decir, con claridad, sin las malas luces que tantos otros estaban brindando. Así, en su inicio nos dice: "Y porque quería cumplir lo que prometí, y se comiencen ya a descrebir algunos de los muchos malos engaños que desta cosa desta tierra la buena fe de quien en absencia y aun en presencia la gobierna recibe, como testigo de vista y experiencia cierta, diré lo que siento". ${ }^{8}$

Justicia y misericordia eran las claves de su tarea de oidor y obispo; en efecto, buscaba defender su dignidad y desplazar todo ataque que se hiciera ante los indios. Por ello, con todo su trabajo pretendía otorgar unas condiciones de desarrollo digno para todos los indígenas que él veía en abuso. Se extendió su acción a los tres pueblos-hospital; al hospital de Santa Marta en Pátzcuaro, desde la que se atendían múltiples casas de salud, y a las instituciones de enseñanza en la capital de su diócesis - el Colegio de Niñas, que pronto desapareció, y el Colegio de San Nicolás, destinado en su inicio a la formación de clérigos-. ${ }^{9}$

\footnotetext{
$6 \quad$ Ibidem, p. 84.

7 Información, p. 10.

$8 \quad$ Ibidem, p. 48.

9 Tena Ramírez, Felipe, op. cit., pp. 37 y 38.
} 
Este libro forma parte del acervo de la Biblioteca Jurídica Virtual del Instituto de Investigaciones Jurídicas de la UNAM

\section{Poder sustentar}

Quiroga es un gran crítico de la situación que encuentra en la Nueva España. Por todos lados se ensalza su labor de oidor y la claridad con la que, especialmente en la Información en derecho, habla sobre los problemas que el pueblo indígena vivía. Pero la postura del oidor no termina en el juicio sobre los males que vivía el pueblo y se vuelve un hombre con una doble inquietud: erradicar la injusticia y establecer la paz. Es en ese entorno en el que la propuesta de Quiroga adquiere un valor estratégico. Quiroga, como comenta González, ${ }^{10}$ responde con un ambicioso proyecto hospitalario como eficaz remedio a la turbulenta situación. Desde el inicio de la Información, Quiroga ya postula sus dos intereses fundamentales y habla de los pueblos de policía mixta como solución factible a la situación de abuso en que vivían los indígenas: ${ }^{11}$

Se muestra como el que ofrece con insistencia soluciones más completas a la vastedad de problemas del Nuevo Mundo. Guiado por un criterio que considere al hombre integralmente, ha formulado y ahora inculca un parecer escrito con anterioridad en que diseña un modelo de comunidades para el Nuevo Mundo, una policía mixta de lo temporal y lo espiritual. ${ }^{12}$

Sorprende en nuestros días que en el planteamiento de Quiroga no aparezca ningún matiz de paternalismo en la atención de los indígenas. La perspectiva subsidiaria se detona desde el inicio, ya que se confía en la organización propia de los pueblos para su subsistencia, otorgándoles tan sólo condiciones de viabilidad que la dinámica de la conquista no estaba permitiendo.

Es cosa de mucha lástima - comenta Quiroga en la Informacióngente tan dócil y capaz y tan apta nata para todo estoy para todo

10 González Cruz, Manuel, op. cit., p. 11.

11 Información, p. 11.

12 Herrejón, Carlos, "Introducción”, en Quiroga, Vasco de, Información en derecho, México, 1985, p. 11. Cfr. Información, II, p. 19; III, pp. 23, 192, 244, 255, 258 y 286. 
Este libro forma parte del acervo de la Biblioteca Jurídica Virtual del Instituto de Investigaciones Jurídicas de la UNAM

cuanto se les mandare por su Majestad y por ese su Real Consejo de las Indias, sin resistencia alguna, y tan humilde y obediente, vivir tan salvajes y derramada y miserable y bestial, por falta desta buena policía y recogimiento de ciudades y de juntarlos y recogerlos en ellas. ${ }^{13}$

Para Quiroga, la dinámica laboral tendría que ser esencial. En entornos de aproximadamente 60,000 personas por comunidad, ${ }^{14}$ Quiroga ofrece una estructura en la que ellos mismos desarrollarían la vida del hospital, de ahí que las ordenanzas señalen fundamentalmente la dinámica laboral del pueblo. Por un lado, todos habrían de tener una participación en el cultivo, ${ }^{15}$ incluso los niños, quienes al menos deberían de trabajar una o dos horas diarias. ${ }^{16}$ Reconociendo el valor del esfuerzo personal, Quiroga garantiza los elementos básicos de vida a todos los miembros del pueblo; sin embargo, aquellos que no quisieran vivir según las costumbres del mismo o trabajar para vivir, tendrían que ser reprendidos y, en su caso, expulsados del pueblo.

En cuanto a las propiedades, todos tendrían uso de la propiedad raíz, pero aquella que fuera fruto del trabajo se podría conservar a título personal. ${ }^{17}$ Para estas propiedades se desarrolla el sistema de cajas de ahorro, que estarán custodiadas por tres llaves distintas para garantizar su protección. ${ }^{18}$

Siguiendo el influjo de Moro, Quiroga no deja de hablar del desarrollo cultural necesario en el pueblo, de modo que en sus pueblos era indispensable el cuidado constante del progreso cultural de los miembros.

13 Información, p. 82.

14 Tena Ramírez, Felipe, op. cit., p. 77.

15 Quiroga, Vasco de, Ordenanzas de Santa Fe (introducción, paleografía y notas por J. Benedict Warren), Morelia, Fimax Publicistas, 1999, p. 2. De ahora en adelante esta obra se citará como Ordenanzas, seguida del número de página.

16 Ibidem, p. 9.

17 Tena Ramírez, Felipe, op. cit., p. 80.

18 Ordenanzas, p. 20. 
Este libro forma parte del acervo de la Biblioteca Jurídica Virtual del Instituto de Investigaciones Jurídicas de la UNAM

Quiroga mantuvo desde sus primeros días de fundación de los pueblos, gracias a las grandes influencias que pudo tener de la memoria de la Iglesia primitiva, la práctica hospitalaria medieval y, evidentemente, el pensamiento de Moro reflejado en la Utopía. ${ }^{19}$ Éstos permitieron al oidor plantear desde el inicio un modelo con una visión trascendente en sus tareas evergetistas, que pudo superar su propia existencia. ${ }^{20}$

\section{Vergüenza}

Si bien fray Juan de Zumárraga señalaba que el trabajo comprometido de Quiroga dejaba en vergüenza a todos los demás por su gran celo, también es cierto que esa misma vergüenza sintió el recién llegado oidor al ver los abusos que se daban al pueblo. De modo que se puede decir que fue la "vergüenza" la que movió a Quiroga y la que despertó, posteriormente, él mismo con su obra.

Se detona esta impotencia cuando escucha aquellas palabras: “Quién podrá favorecernos?”, y Quiroga da un cambio profundo a su vida. Don Vasco desarrolla constantemente una empatía ante el dolor vivido por el pueblo, ante la pérdida del dominio de sus dioses, ${ }^{21}$ y se convierte en un comprometido firme por la causa de los pueblos.

Todo su trabajo no dejó de ocasionar dificultades en el entorno. Algunos lo veían con gratitud, pero otros como un adversario incómodo. ${ }^{22}$ Fray Juan de Zumárraga en otra ocasión señaló: "El licenciado Quiroga nos da buena lección y hasta reprensión... con todo lo que hace en gastar cuanto tiene en estos hospitales

19 González desarrolla ampliamente estas influencias que tiene Moro al analizar el trabajo evergético de Quiroga. Cfr. González Cruz, Manuel, op. cit., pp. 117-163.

20 Tena Ramírez, Felipe, op. cit., p. 127.

21 González Cruz, Manuel, op. cit., p. 89.

22 Ibidem, p. 12. 
Este libro forma parte del acervo de la Biblioteca Jurídica Virtual del Instituto de Investigaciones Jurídicas de la UNAM

y congregaciones y en ejercitar todas las buenas otras de misericordia con ellos". ${ }^{23}$

Es una lástima que el testimonio de Quiroga sólo haya terminado en la vergüenza y no hubiera podido suscitar como él, un compromiso por "favorecer" a aquellos que clamaban ante la injusticia. Aunque los pueblos-hospital de Quiroga fueron inspiración para muchas políticas de la Corona y la futura República, ${ }^{24}$ no se encuentra ningún eco posterior a sus trabajos, e incluso ningún otro ha podido tener la magnanimidad del oidor para fundar este tipo de pueblos, en los que el compromiso por dar un entorno sustentable pudiera ofrecer oportunidades a tantos que siguieron y siguen clamando ante la injusticia.

Todo esto nos permite concluir considerando la Magnanimidad de Quiroga, aquella que Aristóteles señalaba en la Ética a Nicómaco como culmen de la virtud, la de aquel que: no se expone al peligro por bagatelas ni ama el peligro, porque estima pocas cosas, pero afronta grandes peligros, y cuando lo hace no regatea su vida, porque piensa que no es digna de vivirse de cualquier manera. ${ }^{25}$

\section{REPERCUSIÓN DE SU PENSAMIENTO-LABOR EN SUS PUEBLOS}

\section{Riquezas}

\section{A. Reconocer que tienen dignidad personal y social}

La primera manifestación de la grandeza de Quiroga viene con la firme defensa a la dignidad de todo ser humano y, por tanto, al

23 Aguayo Spencer, R., Don Vasco de Quiroga. Documentos, México, Polis, 1939, p. 443.

24 Es importante señalar que la dinámica de los pueblos-hospital sirvieron de modelo para el municipio libre. Cfr. Tena Ramírez, Felipe, op. cit., p. 129.

25 Aristóteles, Ética a Nicómaco, Madrid, Centro de Estudios Políticos y Constitucionales, 2002, 1124 b7. 
Este libro forma parte del acervo de la Biblioteca Jurídica Virtual del Instituto de Investigaciones Jurídicas de la UNAM

reconocimiento de esa dignidad a los pueblos indígenas en todas sus implicaciones. No se puede olvidar que el fundamento de todo derecho o principio es la dignidad humana. ${ }^{26}$ Éste es el fundamento de su larga lucha en defensa de la no esclavitud de los pueblos indígenas; también es uno de los motores que impulsaron a Quiroga a participar en la defensa de los pueblos indígenas. Al llegar al Nuevo Mundo, Quiroga se encuentra con "el triunvirato de la iniquidad y el desgobierno" 27 de los primeros oidores: Nuño de Guzmán, Matienzo y Delgadillo.

Asimismo, Quiroga se topa con el decreto de la nueva provisión, en la que se permitía la esclavitud por parte de los caciques - fingidos cristianos comenta él—, ${ }^{28}$ quienes terminan haciendo la guerra contra los indios con tal de tenerlos bajo su poder. Por ello, los tres primeros capítulos de la Información en derecho se dirigen justamente a aclarar el abuso al que se lleva al permitir la esclavitud; en este sentido, hace suya una frase de san Juan Crisóstomo, en la que dice:

En efecto, si consideramos acción gravemente abominable derrumbar un edificio sagrado, cuánto más criminal es convertir en ruinas el templo espiritual, puesto que nos consta que la persona humana es mucho más sagrada que los edificios religiosos; ya que Cristo cubrió la santidad de este templo nuestro no con el arte de muros y bóvedas, sino con su propia muerte. ${ }^{29}$

A la defensa de ese "templo", Quiroga luchó y descansó con la abolición de la esclavitud en 1542. Pero, al mismo tiempo, el reconocer la dignidad lleva a Quiroga a hablar de la dignidad de los usos y costumbres de estos pueblos, que a pesar de que tam-

26 El Compendio de la doctrina social de la Iglesia dedica su capítulo tercero a la dignidad de la persona, vista como fundamento de todos los principios de la doctrina social desarrollados en el capítulo cuarto. Cfr. Pontificio Consejo "Justicia y Paz”, Compendio de la doctrina social cristiana, Santiago, San Pablo, 2005, pp. 87-120.

27 Frase de Solórzano Pereyra señalada por González. Cfr. González Cruz, Manuel, op. cit., p. 117.

28 Información, p. 5.

29 Crisóstomo, Juan, Opera Omnia, Basilea, 1525, v. 126 (P. C.). 
Este libro forma parte del acervo de la Biblioteca Jurídica Virtual del Instituto de Investigaciones Jurídicas de la UNAM

bién en muchos casos se encontraban subyugados por la tiranía de Moctezuma, ésta se dirigía fundamentalmente a los tributos y no a las prisiones y esclavitud aplicadas por los caciques. ${ }^{30}$ Reconocer que tienen organización y que la tiranía está terminando con ella preocupa a Quiroga tanto como la primera dignidad. A su vez, él considera que si no se generan estos pueblos terminarán desapareciendo, y urge a consolidar un esfuerzo para que esto no siga sucediendo. ${ }^{31}$

Aunque en la Información habla de todos los vicios sociales que los pueblos indígenas tenían y que justificaban con frecuencia la intervención del reino español en la evangelización de los pueblos, Quiroga siempre construye sus ideales de pueblo-hospital sobre la base del concepto de familia, la cual puede ser rústica o urbana, y en cuya acepción se incluyó no sólo el grupo, sino también la morada habitacional. ${ }^{32}$

Igualmente, Quiroga destaca el valor de las diversas comunidades indígenas y sus tradiciones, al grado que asigna a los chichimecas el pueblo de Santa Fe del Río y a los tarascos el pueblo de Santa Fe de la Laguna, ${ }^{33}$ ambos con el recurso a la policía mixta - inspirada en Moro - ${ }^{34}$ como esa propuesta fundamental que en la Información sugiere a su interlocutor.

\section{B. Reconocer que el sistema los ha marginado, y su relación al mismo los lleva a estar en desequilibrio con muchas dificultades para el desarrollo a corto, mediano y largo plazo}

La razón fundamental del desarrollo de los pueblos-hospital es la marginación a la que la conquista ha llevado a los pueblos

30 Información, pp. 18-21.

31 "Porque esta sola causa e dolencia les basta para que todos en breve se consuman por estar así solos e derramados, por no ser bastante manera la que al presente tienen para sufrir mucho tiempo la carga que llevan a las cuestas, de trabajos y tributos e servicios". Cfr. Información, p. 34.

32 Tena Ramírez, Felipe, op. cit., p. 99.

33 Ibidem, p. 153.

34 Información, p. 15. 
Este libro forma parte del acervo de la Biblioteca Jurídica Virtual del Instituto de Investigaciones Jurídicas de la UNAM

indígenas. De no ser por eso, aquéllos no serían necesarios, pero las nuevas condiciones de vida los han impulsado cada vez más lejos de su entorno de dignidad.

Bartolomé de las Casas realizó algunos intentos por proteger a los pueblos, buscando un equilibrio entre la convivencia y la encomienda. ${ }^{35}$ Estos intentos no tuvieron mucho éxito; incluso, se seguían detonando muchos abusos en la conquista, de los que da cuenta en la Información en derecho. La encomienda, lejos de ser un esquema que ayudará a la convivencia pacífica y la explotación de las riquezas de la tierra, se presentaba como una ocasión para el abuso. Para Quiroga, las pestes y las encomiendas fueron los dos grandes ataques a los pueblos; ${ }^{36}$ por tal motivo, tuvo que realizar una fuerte defensa frente al encomendadero Juan Infante, quien pretendía reducir a los pueblos, ${ }^{37}$ y denunciar fuertemente a lo largo de todo el texto de la Información, los abusos que por parte de ellos se presentaban tanto en el campo como, principalmente, en las minas.

\section{Otorgarles condiciones especiales para su desarrollo}

Por todo ello, los pueblos-hospital reclamaban gozar de condiciones especiales para su desarrollo, que permitieran vivir en un entorno ajeno a la opresión y en el que se favoreciera el crecimiento de los miembros de la comunidad.

a. Trato a los indígenas

Para Quiroga, el trato a los indígenas era una prioridad; en ellos veía reflejado al mismo Cristo, a quien defendía con su propia vida:

\footnotetext{
35 Tena Ramírez, Felipe, op. cit., p. 73.

36 Ibidem, p. 162.

37 Ibidem, p. 45.
} 
Este libro forma parte del acervo de la Biblioteca Jurídica Virtual del Instituto de Investigaciones Jurídicas de la UNAM

Quiroga empeñó largos debates litigiosos durante su estancia en Nueva España hasta su muerte, en grado tal que su actividad aquí da la impresión de haber estado solicitada simultáneamente por el pleito y por la caridad. No se trataba, en el fondo, de tendencias opuestas, pues generalmente las unificaba el común designio de entrega a favor de los humildes y de defensa de aquello que por sí o por su mediación les entregaba. ${ }^{38}$

Con ellos siempre fue suave Quiroga, pero defendió con vehemencia muchos de sus oficios. ${ }^{39}$

\section{b. Patronato}

Lo que principalmente benefició a los pueblos-hospital fueron las condiciones excepcionales que les generó. Estas condiciones estuvieron apoyadas por el rey, quien llegó a poner penas a aquellos que llegaran a romperlas. ${ }^{40}$

La autonomía fue el rasgo fundamental que vivían los pueblos-hospital. Dicha autonomía era capaz, incluso, de superar la autoridad del arzobispo de México, quien no podría poner o asignar al capellán del Pueblo de Santa Fe, mismo que era instituido por el cabildo de la Catedral de Michoacán. ${ }^{41}$

La estrategia de asignar el patronazgo de los pueblos al cabildo de la diócesis tenía una doble astucia: por un lado, la de no permitir que el trabajo a largo plazo se viniera abajo con la llegada de un nuevo obispo, y por otro lado, que el decreto de elección no viniera por orden del rey, sino por el grupo de clérigos que mayor cercanía podrían tener de los pueblos-hospital y que, por consiguiente, mejor podrían elegir al capellán de los mismos y mantener un cuidado cercano del ejercicio de sus funciones.

Esta autonomía otorgada a los pueblos es la base de lo que posteriormente se constituyó como municipio libre; estuvo tan

\footnotetext{
38 Ibidem, pp. 38 y 39.

39 Ibidem, p. 41.

$40 \quad$ Ibidem, p. 116.

41 Ibidem, p. 113.
} 
Este libro forma parte del acervo de la Biblioteca Jurídica Virtual del Instituto de Investigaciones Jurídicas de la UNAM

bien dotada que subsistió tras la independencia por su estructura interna. ${ }^{42}$

Ellos existieron hasta el siglo XIX; incluso, superaron la nacionalización realizada por Juárez en 1859 y la desamortización de 1856. Dichos pueblos terminaron más bien por la falta del compromiso quiroguiano, que con el paso de los años fue perdiendo el cabildo de Michoacán para defender los pueblos y buscar su desarrollo. En el Acta de extinción de los pueblos (3 de febrero de 1872) se dan dos razones que más de alguno considera absurdas: la falta de fondos y el tiempo. ${ }^{43}$

\section{Debilidades}

A pesar de las grandezas del trabajo realizado por Quiroga en la consolidación de dichos pueblos-hospital, se podría destacar como principal fallo la planeación del camino de subsidiariedad que ellos deberían de vivir. La ausencia del fundador hizo que faltara el magnetismo que libraba a los pueblos-hospital de la sombra de utopía; ${ }^{44}$ la impronta que el mismo fundador otorgó a los pueblos no permitió con facilidad duplicar este tipo de empresas. ${ }^{45} \mathrm{El}$ cabildo, quien asume por estatutos el patronato de los pueblos-hospital, aunque encausa las labores cotidianas - como se manifiesta en las Actas del cabildo, que de ordinario hacen alguna referencia al cuidado de los pueblos-, no tuvo el papel de líder que el obispo había adquirido.

A pesar de que se alaba todo el tiempo que los pueblos-hospital se mantuvieron, no lo es tanto el que tuvieran que existir por un periodo tan extenso con prerrogativas especiales que no dejaban de apartarlos del desarrollo común de los pueblos. Este hecho factiblemente lo pudo haber considerado Quiroga en sus Ordenanzas o en su Testamento, pero no fue así.

\footnotetext{
42 Ibidem, p. 142.

43 Ibidem, p. 172.

44 Ibidem, p. 94.

45 Ibidem, p. 160.
} 
Este libro forma parte del acervo de la Biblioteca Jurídica Virtual del Instituto de Investigaciones Jurídicas de la UNAM

\section{Fundamentación de sus pueblos en la actual doctrina social}

Los pueblos-hospital se pueden ver como un entorno de compromiso social por los más necesitados a la medida del buen samaritano, un espacio que toma a la persona en su plenitud y su entorno social, ofreciéndole las condiciones de vida y desarrollo necesarias, las cuales custodia con un patronato que va velando por su bienestar y espera que alcancen el desarrollo sustentable de sus miembros mediante un orden social moral comprometido.

\section{A. Principios de la doctrina social cristiana}

Siguiendo el índice del Compendio de la doctrina social cristiana, se pueden encontrar las correspondencias en la estructura de los pueblos-hospital casi para todos los aspectos. Desde el compromiso que todo ser humano tiene con los demás hasta el derechodeber de la Iglesia de preocuparse por estos temas y no sólo por la evangelización, ${ }^{46}$ Quiroga se muestra desde los inicios de su vocación, comprometido tanto con la justicia y la paz como con un proyecto de justicia y misericordia, que empaparon su labor de oidor y, posteriormente, obispo. ${ }^{47}$

El fundamento en la dignidad de la persona lo manifiesta en cada uno de los textos y acciones de su vida, defendiendo siempre a la persona de todo ataque, de modo especial de los encomendaderos y la corta vigencia de la ley a favor de la esclavitud. Vasco de Quiroga fue un hombre que procuró hacer valer la justicia y dar el paso a la misericordia, con la conciencia de que ésta no se puede dar sin aquélla, empero que aquélla reclama a la misericordia para que sea plena. Así, Vasco de Quiroga se dio a la tarea de hacer valer la justicia ante la opresión, pero de hacer brillar la misericordia para el desarrollo de los pueblos, de abrirlos a la trascendencia para alcanzar en ella un horizonte más pleno y gozoso.

46 Pontificio Consejo "Justicia y Paz", op. cit., pp. 55-87.

47 González Cruz, Manuel, op. cit., p. 68. 
Este libro forma parte del acervo de la Biblioteca Jurídica Virtual del Instituto de Investigaciones Jurídicas de la UNAM

Se podría hacer mención de los principales principios de la doctrina social: bien común, destino universal de los bienes, subsidiariedad y solidaridad. Los ecos de cada uno de ellos son manifiestos. La policía mixta pensada por Quiroga pone al centro de la comunidad el bien común que ha de velarse sobre cualquier particular, fundamento del destino universal de los bienes que, para el oidor-obispo, eran fundamentales. Cada quien podía hacer uso de la tierra, pero primando su uso común, tanto como lo eran para todos los bienes que pudieran ser de utilidad al pueblo, justificando tan sólo por la dinámica del trabajo la posesión de los bienes fruto del mismo, para los que incluso organizó las cajas de ahorro con tres llaves, que más de alguna organización implementa aún en nuestros días.

Era clara la solidaridad que con los pueblos-hospital se vivía y se pedía vivir al entorno, ya que eran los más desfavorecidos de los habitantes de la Nueva España y con los que se debería vivir un compromiso mayor. Con su ejemplo y con el dinamismo de sus pueblos impulsó el ideal básico de la solidaridad: la voluntad firme y perseverante de buscar el bien común. Su firmeza y perseverancia en la constitución y defensa de los pueblos fue manifiesta a lo largo de su vida y en el espíritu que pudo heredar a los pueblos por medio de sus Ordenanzas y sus últimas voluntades.

Sin embargo, la subsidiariedad en los pueblos-hospital presenta ciertas debilidades, principalmente porque no terminó por considerar el momento en el que los pueblos-hospital dejaran de ser un patronato que, se quiera o no, separara su dinámica de vida de la de los pueblos circundantes. No se presentaba en el horizonte de trabajo el momento de madurez de los habitantes para dejar dichas condiciones y terminar por integrarse completamente en la sociedad. Incluso, en el Acta de extinción de los pueblos se apela a la ausencia de fondos para el mismo, pero no se deja entrever con claridad que la suspensión del patronazgo fuera por haber cumplido sus objetivos. ${ }^{48}$

48 Tena Ramírez, Felipe, op. cit., p. 172. 
Este libro forma parte del acervo de la Biblioteca Jurídica Virtual del Instituto de Investigaciones Jurídicas de la UNAM

Esta carencia subsidiaria no hace de los pueblos-hospital ni un entorno plenamente paternalista ni insuficiente para el fin buscado, sino simplemente abre la oportunidad de un replanteamiento a la dinámica de trabajo de los mismos pueblos.

\section{B. Ecos con el papa Francisco}

La lectura de la Información en derecho recuerda en más de una vez los actuales documentos publicados por el papa Francisco. Muchos ecos podrían encontrarse en un estudio más pormenorizado, mas se presentan dos que se consideran de mayor relevancia.

El primero de ellos es su voz ante el egoísmo que genera indiferencia y produce la injusticia de la desigualdad, que es considerada como una marginación e, incluso, esclavitud. Los dos personajes, Quiroga y Francisco, hacen hincapié una y otra vez en la carencia de un verdadero y sincero compromiso comunitario que busque el bien común. El obispo de Roma refiere de manera constante a la cultura del consumismo que encierra a las personas en sí mismas, convirtiéndolas en un instrumento del sistema económico imperante y limitándolas en su desarrollo. ${ }^{49} \mathrm{El}$ obispo de Michoacán, en su Información en derecho, no dejó de hablar de la codicia, al señalar a los caciques como fingidos cristianos que dados a sus placeres personales abusaban de los meceoales, quienes quedaban en un régimen de esclavitud.

La segunda sintonía destacable es la preocupación sincera por construir un nuevo orden social. Son más de diez ocasiones en las que el papa Francisco ha instado a generar un nuevo orden social que permita palear las injusticias de la época actual e imperante. Para reducir las enormes brechas que se generan en una sociedad centrada en el consumismo, se debe eliminar el utópico sueño del progreso ilimitado que terminará desarrollando a todos,

49 Francisco, "Evangelii Gaudium", Acta Apostolicae Sedis 105, Vaticano, Libreria Editrice Vaticana, 2013, 209-216; id., "Laudato Si", Acta Apostolicae Sedis 107, Vaticano, Libreria Editrice Vaticana, 2015, 49-52. 
Este libro forma parte del acervo de la Biblioteca Jurídica Virtual del Instituto de Investigaciones Jurídicas de la UNAM

utopía manifiesta en la experiencia de los últimos de gran desarrollo y mayor marginación. Este deseo de un nuevo orden es el que justamente implanta el obispo de Michoacán en sus puebloshospital; es cierto, fue un orden para un entorno específico, pero que no deja de hacer eco actual para la búsqueda de ese nuevo orden. El obispo de Roma, desde su sede, no deja de invitar a la humanidad a tomar un compromiso más sólido, a fortalecer las acciones ya iniciadas, pero a buscar consolidar - hecho que les solicita a los jóvenes en particular - la cultura de la solidaridad como centro de la dinámica de vida. ${ }^{50}$

\section{UNA DINÁMICA DE DETONACIÓN \\ DE LOS MISMOS PUEBLOS EN NUESTROS DÍAS}

A manera de corolario se presenta ahora el planteamiento del encuentro del mundo vivido por Quiroga a su llegada a la Nueva España con las condiciones actuales de México, y el planteamiento de la actual necesidad de industrias como la suya de los puebloshospital.

\section{Fustificación del planteamiento}

\section{A. Marginación del pueblo}

El gobierno ofreció hace pocos meses por medio del Coneval, los nuevos indicadores de la pobreza en el país. El incremento de los pobres fue tema de conversación y crítica por algunas semanas; sin embargo, como sucede en la posmodernidad regida por él sin fundamento, la problemática ha perdido su existencia entitativa para trasladarse a la existencia mediática. Así pues, tenemos que hay 55.3 millones de pobres en el país, 11.4 millones

50 Francisco, "Viaje apostólico a Río de Janeiro", Acta Apostolicae Sedis 105, Vaticano, Libreria Editrice Vaticana, 2013. 
Este libro forma parte del acervo de la Biblioteca Jurídica Virtual del Instituto de Investigaciones Jurídicas de la UNAM

en extrema pobreza y un $79.5 \%$ de la población está en estado de vulnerabilidad, es decir, sólo el $20.5 \%$ de los mexicanos $(24.6$ millones) gozan de las condiciones necesarias de vida para poder construir la vida en plenitud; en cambio, el resto debe luchar por sobrevivir.

Dentro de este porcentaje son hoy más los indígenas que viven en estas condiciones. El 73.2\% de ellos se encuentra en condiciones de pobreza y el $31.8 \%$ en extrema pobreza, mientras que en la población no indígena este porcentaje desciende considerablemente en el total de la población pobre y drásticamente en el de la población con pobreza extrema. Así, en tanto que el $31.8 \%$ de los indígenas viven en pobreza extrema, sólo el $7.1 \%$ de la población no indígena lo hace. ${ }^{51}$

\section{B. Condiciones de vida en dificultad de acceso}

De nuevo, como en tiempos de Quiroga, los deciles de menor ingreso son los más marginados de los derechos sociales básicos: el 30\% sin vivienda digna; el 35\% con rezago educativo; el $40 \%$ con privación en el acceso a la alimentación; el 27\% con carencia en los servicios de salud; el 90\% con ausencia en seguridad social, y el 28\% con falta de servicios básicos.

Con estas condiciones no sólo se carece de la dignidad de vida necesaria para el desarrollo personal, sino también se encarece la dinámica de vida cotidiana.

\section{Insuficiencia de las acciones y compromiso}

A pesar de los millones presupuestados para políticas de desarrollo social, de los millones que la población civil destina voluntariamente a estos trabajos y de los millones que el país sigue

51 Pobreza en México 2015, Coneval, 2015, disponible en: http://wrerw.coneval. gob.mx/medicion/Paginas/PobrezaInicio.aspx. 
Este libro forma parte del acervo de la Biblioteca Jurídica Virtual del Instituto de Investigaciones Jurídicas de la UNAM

recibiendo de aportaciones internacionales, los efectos de estos esfuerzos son prácticamente nulos.

Son muchas las asociaciones de la sociedad civil que se han dado a esta tarea (unas 16,000 registradas y activas); pero no son nada frente a los cerca de cinco millones de empresarios - micro, pequeños y grandes - que se dan a la tarea del desarrollo económico del pueblo. Es sobre estos datos que el obispo de Roma hace el llamamiento a un nuevo orden social, a un nuevo modo de vida que sea más justo y misericordioso con todos. ¿Se podría pensar que la dinámica de pueblos-hospital que Quiroga planteó hace ya casi quinientos años pueda seguir siendo válida en el México de hoy?

\section{Claves fundamentales para implementar el proyecto}

Desde hace unos años, un grupo de universitarios, empresarios, organizaciones de la sociedad civil y más personas han estado cuestionándose esta dinámica y buscando dar una respuesta más sólida a esta dificultad. Dentro de ella, en parte inspirados por el ideal del obispo de Michoacán, se han podido resaltar los tres aspectos fundamentales que este nuevo orden debería de tener en cuanto al cuidado de los más necesitados. Estos tres aspectos son considerados también por el miembro de la Segunda Audiencia.

\section{A. Integralidad}

Es necesario afrontar la pobreza de un modo integral. No es la carencia de alimentación, vivienda, recursos, seguridad, educación o salud el problema fundamental, sino es la vida de las personas sin las condiciones necesarias para su desarrollo la que se ha de palear. Por ello, el cuidado de los demás reclama una visión integral de las condiciones esenciales de vida, y dada la condición social de los pueblos, no se puede atender a la dinámica de vida de una persona sin ampliar este trabajo a su entorno social. 
Este libro forma parte del acervo de la Biblioteca Jurídica Virtual del Instituto de Investigaciones Jurídicas de la UNAM

De ahí que el oidor Quiroga hablara de pueblos de unas 60,000 personas, ${ }^{52}$ entorno que puede asegurar una economía interna suficiente, que aunque esté abierto al exterior, garantice las bases para construir una convivencia sana.

\section{B. Largo plazo}

La pobreza — señalaba hace algunos años Juan Pablo II - no es sólo carencia económica, sino fundamentalmente una carencia cultural; por ende, el pobre vive un desplazamiento cultural, pues se le ha marginado del desarrollo ordinario de los pueblos, y ése es el principal problema. Aunque el pobre habite en las grandes urbes, no vive dentro de la cultura de ellas, ya que no son capaces de vivir una dinámica social, con lo cual ellos son excluidos y expulsados de la dinámica de vida.

Para dar paso atrás a este proceso es imperante una dinámica de integración cultural, que como todo movimiento cultural, toma su tiempo y requiere de estrategias de inculturalización hacia ambos lados. Estos procesos reclaman del paso generacional y, por lo tanto, un acompañamiento constante y subsidiario. Éste fue el mayor logro de los pueblos-hospital. Quiroga logró constituir un modelo permanente de transformación social al permitirles a los pueblos ciertas condiciones especiales de desarrollo y colocar en la autoridad del cabildo y no su obispo, ente más estable dentro de la dinámica eclesial. ${ }^{53}$

\section{Sinergia}

Por último, es necesario abrir el horizonte de acción. Así como el marginado no puede fácilmente superar esa condición sin la ayuda de los demás, los que están en condición de ayudar no pueden por sí solos afrontar la inmensa tarea de una transforma-

52 Tena Ramírez, Felipe, op. cit., p. 77.

53 Ibidem, p. 113. 
Este libro forma parte del acervo de la Biblioteca Jurídica Virtual del Instituto de Investigaciones Jurídicas de la UNAM

ción social integral a largo plazo. El problema de la pobreza, de la marginación, no es una cuestión del gobierno, de la Iglesia, de las organizaciones o de algún otro ente social, sino que es un asunto de carácter político, es decir, de todos. Éste es el reflejo de una cultura que permite que la mitad de su población - hablando de México - viva en condiciones de indignidad; por lo tanto, es un reto para toda la población, que en conjunto tendrá que afrontar. Ésa es la luz de la participación, la solidaridad y la subsidiariedad que se reclaman para este proceso.

La participación siempre reclama humildad, y de ahí que esta sinergia reclame, asimismo, en su estructura una dinámica que garantice la adecuada coordinación de los agentes para este desarrollo. En el caso de los pueblos-hospital, al inicio fue la persona de Quiroga quien se hizo responsable de ello; posteriormente, el cabildo pudo haber tenido alguna injerencia, pero ya nunca como la tuvo el entonces oidor. La tarea del desarrollo de los pueblos se le otorgó fundamentalmente a la misma población de los pueblos-hospital. Este hecho es esencial, porque si el marginado no desea superarse, nunca lo hará; pero también es prudente participar en el proceso, tal y como los que saben hablar enseñan a los que no lo saben, o los que saben caminar ayudan a aprender a los que no lo saben. Lo mismo sucede con la marginación, en donde la población con condiciones de dignidad han de asumir el rol subsidiario de educadores en el sentido estricto de la palabra.

En este grupo de reflexión se ha coordinado esta labor en sinergia con el papel protagónico de una universidad, quien por su amplio aspecto del saber es capaz de coordinar las acciones integrales que se tendrían que realizar en un largo plazo, detonando así en su compromiso los tres aspectos fundamentales de su labor universitaria: la docencia, la investigación y el impacto social.

¿Podría este modelo integral a largo plazo y en sinergia ser válido al ejemplo de los pueblos-hospital de Vasco de Quiroga? Son pocos los que por el momento lo van impulsando, pero ya son algunos cuantos miles de involucrados en estos procesos y consolidados institucionalmente los que lo están comenzando a hacer. Cabe destacar, justamente por el proceso que se tiene, el que 
Este libro forma parte del acervo de la Biblioteca Jurídica Virtual del Instituto de Investigaciones Jurídicas de la UNAM

se detona en las barrancas de Santa Fe, lugar de fundación del primer pueblo-hospital. En él y sus alrededores, la Universidad Panamericana comienza un proyecto a largo plazo con pretensión de integralidad en sinergia con muchas otras organizaciones para ayudar a la dignificación de la zona. Es emblemática la foto que se tiene desde el aula de cómputo del centro, a través de la cual se ve por una ventana la torre del templo de Santa Fe y por la otra, a lo lejos, la casa-ermita en la que por algún tiempo vivió Vasco de Quiroga.

\section{GRATITUd a QUiRoga, A MOdO DE CONCLUSIÓN}

Concluíamos la introducción a este escrito planteando una intrigante cuestión: ¿por qué no hubo más pueblos-hospital en tiempos de Quiroga, en el resto de la Nueva España ni en nuestros días? Sé que es una pregunta que no tiene una respuesta definitiva y que muchas cosas se podrían especular; sin embargo, permítanme señalar algunos puntos. Por un lado, hoy día continúa siendo necesario algún tipo de pueblos-hospital que atiendan las mismas - o similares - condiciones de indignidad de gran parte de la población de nuestro país y del mundo entero. En segundo lugar, se podría hablar que a pesar de que existan sus excepciones, la voluntad de solucionar la marginación es prácticamente universal. No se encuentra de ordinario gente que quiera que sigan habiendo pobres, marginados, esclavizados y condiciones de vida inhumanas. En efecto, no sólo "Los objetivos del milenio" de la ONU planteaban que justamente para este año se redujera el $50 \%$ de la población en extrema pobreza, sino que ahora muchos foros se dedican a estos temas, y la solidaridad universal aflora constantemente ante las desgracias naturales o sociales que acontecen en el mundo, pero no así ante la desgracia estructural que genera la cultura actual.

Ahora bien, ¿por qué si es necesario y la gente quiere que suceda no pasa nada? Creo que esto ya toca las fibras íntimas del 
Este libro forma parte del acervo de la Biblioteca Jurídica Virtual del Instituto de Investigaciones Jurídicas de la UNAM

problema que llevan al corazón del hombre y la crisis cultural que en nuestros días vivimos. Es preciso que existan hombres preparados para asumir este reto y que tengan la virtud suficiente para hacerlo.

\section{$\mathrm{Al}$ respecto, Ortega y Gasset decía:}

Yo he buscado en torno, con mirada suplicante de náufrago, los hombres a quienes importase la verdad, la pura verdad, lo que las cosas son por sí mismas, y apenas he hallado alguno. Los he buscado cerca y lejos, entre los artistas y entre los labradores, entre los ingenuos y los "sabios". Como Ibn-Batuta, he tomado el palo del peregrino y hecho vía por el mundo en busca, como él, de los santos de la Tierra, de los hombres de alma especular y serena que reciben la reflexión del ser de las cosas. ¡Y he hallado tan pocos, tan pocos que me ahogo! Sí: congoja de ahogo siento, porque un alma necesita respirar almas afines, y quien ama sobre todo la verdad necesita respirar aire de almas veraces. No he hallado de derredor sino políticos, gentes a quienes no interesa ver el mundo como él es, dispuestas a usar de las cosas como les conviene. ${ }^{54}$

Nuestro mundo está sediento de gente que se encuentre dispuesta a buscar la verdad y actuar en consecuencia, y que asuma los ideales de justicia y misericordia de Quiroga. Pero para ello es preciso una serie de características personales que no son fáciles de conseguir.

Creo que si Quiroga lo logró hacer, fue justamente porque se desempeñó como un evergeta magnánimo. Si en nuestros días no acontecen empresas similares no es por la falta de ideas o deseos, sino por la falta de convicciones profundas que el obispo de Michoacán cultivo desde su infancia hasta su muerte y que lo condujeron en todas sus acciones. Por tanto, es a él a quien le recae a la perfección el elogio de la magnanimidad de Aristóteles, que hoy día seguimos buscando y que esperamos encontrar en más hombres como él: "Parece, por tanto - nos dice Aristóteles en su Ética a Nicómaco-, que la magnanimidad es un como orna-

54 Ortega y Gasset, José, El espectador, Estella, Salvat Editores, 1983, p. 16. 
Este libro forma parte del acervo de la Biblioteca Jurídica Virtual del Instituto de Investigaciones Jurídicas de la UNAM

to de las virtudes: pues las realza y no se da sin ellas. Por eso es difícil ser de verdad magnánimo, porque no es posible sin cabal nobleza". ${ }^{55}$

\section{BIBLIOGRAFÍA}

Aguayo Spencer, R., Don Vasco de Quiroga. Documentos, México, Polis, 1939.

ARIstóteles, Ética a Nicómaco, Madrid, Centro de Estudios Políticos y Constitucionales, 2002.

ARQUIDIÓCESIS DE MÉXICO, Evangelización de las culturas en la Ciudad de México. II Sinodo Diocesano, México, Arquidiócesis Primada de México, 1995.

Benedicto XVI, "Caritas in veritate", Acta Apostolicae Sedis 101, Vaticano, Libreria Editrice Vaticana, 2009.

Campos, L., "Métodos misionales y rasgos bibliográficos de don Vasco de Quiroga según Cristóbal Cabrera", en VARIOS AUTORES, Don Vasco de Quiroga y arzobispado de Morelia, México, JUS, 1965.

Crisóstomo, Juan, Opera Omnia, Basilea, 1525.

Cuevas, Mariano, Documentos inéditos del siglo XVI para la historia de México, 2a. ed., México, Porrúa, 1975.

Francisco, "Evangelii Gaudium", Acta Apostolicae Sedis 105, Vaticano, Libreria Editrice Vaticana, 2013.

, "Laudato Si", Acta Apostolicae Sedis 107, Vaticano, Libreria Editrice Vaticana, 2015.

"Viaje apostólico a Río de Janeiro", Acta Apostolicae Sedis 105, Vaticano, Libreria Editrice Vaticana, 2013.

GonzÁlez Cruz, Manuel, Teología de la misericordia, implícita en los escritos y en la praxis de Vasco de Quiroga, México, UPM, 2012.

Herrejón, Carlos, "Introducción”, en Quiroga, Vasco de, Información en derecho, México, 1985.

55 Aristóteles, op. cit., $1124 \mathrm{a}$. 
Este libro forma parte del acervo de la Biblioteca Jurídica Virtual del Instituto de Investigaciones Jurídicas de la UNAM

LEÓN, Nicolás, El Ilmo. Señor don Vasco de Quiroga, primer obispo de Michoacán. Grandeza de su persona y de su obra, con apéndice documental, México, Tip. Sucs. Díaz de León, 1903.

Llano, Alejandro, Humanismo cívico, Madrid, Ariel, 1999.

Ortega y Gasset, José, El espectador, Estella, Salvat Editores, 1983.

PABlo VI, "Gaudium et Spes", Concilio Ecuménico Vaticano II, Madrid, BAC, 2004.

Pobreza en México 2015, Coneval, 2015, disponible en: http://wrere. coneval.gob. $\mathrm{mx} /$ medicion/Paginas/PobrezaInicio.aspx.

Pontificio Consejo "Justicia y PAZ", Compendio de la doctrina social cristiana, Santiago, San Pablo, 2005.

Quiroga, Vasco de, De debellandis indis, trad. de René Acuña, México, UNAM, 1988.

—, Información en derecho, México, 1985.

—, Ordenanzas de Santa Fe (introducción, paleografía y notas por J. Benedict Warren), Morelia, Fimax Publicistas, 1999.

Tena Ramírez, Felipe, Vasco de Quiroga y sus pueblos de Santa Fe en los siglos XVIII y XIX, México, Porrúa, 1990. 
Este libro forma parte del acervo de la Biblioteca Jurídica Virtual del Instituto de Investigaciones Jurídicas de la UNAM

\title{
LA TEOLOGÍA DE LA HOSPITALIDAD, IMPLÍCITA EN EL PENSAMIENTO Y EN LA PRAXIS DE VASCO DE QUIROGA*
}

\author{
Manuel GonzÁlez Gruz
}

\begin{abstract}
SUMARIO: I. Introducción. II. El oidor Quiroga y la dramática situación de los vencidos (1531). III. La respuesta de Quiroga: los hospitales-pueblo. IV. Los hospitales-pueblo, ¿una kainè pólis novohispana? V. Conclusión. VI. Bibliografia.
\end{abstract}

\section{INTRODUGCIÓN}

El estudioso francés Jean Imbert advertía a sus lectores tanto de la ambigüedad semántica del término "hospital" como de su función de tasación. Apelando al juicio que de esa benéfica institución hizo el insigne médico francés Jacques-René Tenon (1724-1816), Imbert enfatizaba que "...les hôpitaux sont, en quelque sorte, la mesure de la civilisation d'un peuple". ${ }^{1}$

Considero que el dictamen que Imbert y Tenon hacen del hospital se puede extender a la "hospitalidad" misma, pues aquél ha sido un espacio privilegiado en el que ésta se ha practicado desde la antigüedad. Jean Daniélou (1905-1974), en un memorable artículo sobre la que él llamó teología de la hospitalidad, se expresó

* Se advierte a los posibles lectores que en este trabajo se respeta la ortografía y la puntuación de los textos antiguos en lengua castellana utilizados.

1 Imbert, Jean, "Introduction", en Imbert, Jean (dir.), Histoire des hôpitaux en France, Toulouse, Privat, 1982, p. 11. También véase Mollat, M., "La vie quotidienne dans les hôpitaux médievaux", en Imbert, Jean (dir.), Histoire des hôpitaux en France, Toulouse, Privat, 1982, p. 99. 
Este libro forma parte del acervo de la Biblioteca Jurídica Virtual del Instituto de Investigaciones Jurídicas de la UNAM

casi en los mismos términos que Tenon e Imbert: "L'hospitalité, escribió, est d'abord une grande réalité humaine. Les grecs y voyaient un des traits marquants du peuple civilisé; et on peut dire, en un sens, que sa conception de l'hospitalité est ce qui caractérisait le degré de civilisation d'un peuple ou d'une race". ${ }^{2}$

La historia de la hospitalidad, al igual que la de los hospitales, muestra que a lo largo de la misma han existido algunas variantes en su comprensión y en su práctica; pero esa misma historia señala también que en una de ellas — la cristiana - se refleja un plus cualitativo que la distingue significativamente de las iniciativas evergético-hospitalarias que conoció la Antigüedad clásica. El vasto y diferenciado universo de iniciativas de este género, al igual que su fuerza impulsora - es decir, el amor compasivo y misericordioso - , han de ser tomados en consideración para enmarcar, entender y justipreciar los hospitales-pueblo erigidos en la Nueva España por el varón universal (F. Miranda): Vasco de Quiroga. De esta temática me ocuparé en esta contribución a la celebración del 450 aniversario de la muerte de ese "personaje muy grande y muy complicado" (B. Warren) que fue don Vasco de Quiroga.

\section{EL OIDOR QUIROGA Y LA DRAMÁTICA SITUACIÓN DE LOS VENCIDOS (1531)}

Cuando Quiroga llega a México-Tenochtitlan, a principios de enero de 1531, encuentra una ciudad todavía en ruinas y una población nativa profundamente afectada por las secuelas de la conquista "a fuego y sangre", por el proceso de colonización (física, mental y espiritual), y, no en menor escala, por las vejaciones y los atropellos que les habían inferido primero los conquistadores y luego los que habían llegado al Altiplano para impartir justicia: los corruptos

2 Daniélou, Jean, "Pour une théologie de l'hospitalité", La Vie Spirituelle 84, 1951, pp. 339 y 340. También véase Hiltbrunner, O., "Gastfreundschaft", $R A C$, VIII, 1972, p. 1083. 
Este libro forma parte del acervo de la Biblioteca Jurídica Virtual del Instituto de Investigaciones Jurídicas de la UNAM

y codiciosos miembros de la Primera Audiencia, "la Audiencia del diablo y de Satanás". 3

El benemérito fraile minorita, Bernardino de Sahagún (14991590), resumió de modo lapidario los resultados de la conquista de Tenochtitlan: a sus habitantes, consignó en opus magnum, “...ninguna apariencia les quedó de lo que eran antes". Su parecer concuerda con el del cronista Juan Bautista Pomar (1535-?), quien hizo notar que aquellos pobladores de México-Tenochtitlan estaban dominados por una profunda "congoja y fatiga de su espíritu...". 4

Quiroga, por su parte, describe su percepción de la situación de los vencidos en su "Carta al Consejo" (1531), en su Información en derecho (1535) y en su Testamento, firmado unos meses antes de su deceso. En este importante escrito, nuestro personaje da cuenta de la terrible situación de los que él llamaba naturales destas partes y, asimismo, de su personal reacción afectiva y efectiva: la compasión/misericordia para con los más pobres de los vencidos, a cuya situación pretendía poner "remedio" mediante la implantación de hospitales:

...siendo oydor por su magestad del emperador don carlos quinto y rey despaña nuestro señor en la chancilleria real que reside en la ciudad de mexico. y muchos años antes de tener orden eclesiastica alguna ni renta de iglesia nouido de deuoçion y compasion de la miseria $\mathrm{E}$ incomodidades grandes y pocas vezes vistas. ni oydas que padesçen los yndios pobres huerfanos y miserables personas, naturales destas partes... funde y docte a mi costa y de mis propios salarios con el fauor de dios... dos hospitales de yndios que yntitule de santa Fe... para sustentaçion y doctrina, asy espiritual como

3 Bernand, C. y Gruzinski, S., Historia del Nuevo Mundo. Del descubrimiento a la conquista. La experiencia europea, 1492-1550, México, Fondo de Cultura Económica, 1996, p. 312; Ricard, R., La conquista espiritual de México. Ensayo sobre el apostolado y los métodos misioneros de las órdenes mendicantes en la Nueva España de 1523-1524 a 1572, México, Fondo de Cultura Económica, 1994, p. 379.

4 Para las referencias, véase Sahagún, B. de, Historia general de las Indias (edición crítica y apéndices de A. Ma. Garibay K.), México, Porrúa, 1989, p. 18. Con respecto al texto de Bautista Pomar, véase Todorov, T., La conquista de América. El problema del otro, México, Siglo XXI, 1995, p. 146. 
Este libro forma parte del acervo de la Biblioteca Jurídica Virtual del Instituto de Investigaciones Jurídicas de la UNAM

moral exterior y buena poliçia de... yndios pobres y miserables personas, pupilos, viudas, huérfanos... ${ }^{5}$

Esta lacónica descripción de la lamentable situación de la tierra y de los habitantes de México-Tenochtitlan, la cual ha de completarse con datos dispersos en su Información en derecho, ${ }^{6}$ se ha de interpretar a la luz del texto bíblico que rubrica lo mismo: la franca denuncia del "infierno de las minas", ubi nullus ordo sed sempiternus horror habitat, la aspiración y "la escuela" para que los indios "sean bastantes". El recurso al texto canónico ${ }^{7}$ añade un plus teológico a las descripciones quiroguianas de la lacerante realidad de los vencidos, pues muestra que la lectura que de ella hace el oidor no es simplemente la de un funcionario real, sino la de un cristiano comprometido, con el que él llamará más tarde Evangelio eterno o Evangelio de la vida. ${ }^{8} \mathrm{El}$ texto escogido por Quiroga para describir la situación de los aztecas derrotados dice:

...vi las calumnias que se levantan debajo del sol y las lágrimas de los inocentes, sin haber nadie que los consuele; y la imposibilidad en que se hallan de resistir a la violencia, estando destituidos de todo socorro. Por lo que preferí el estado de los muertos al de los vivos; y juzgué más feliz que unos y otros al hombre que no ha nacido ni ha visto los males que se hacen debajo del sol. ${ }^{9}$

Una descripción más sistemática y más englobante de esa realidad la podemos concentrar en los siguientes tres conceptos: dispersión, despoblación y destrucción, ampliamente documenta-

5 Quiroga, Vasco de, Testamento (edición facsimilar con otros documentos. Introducción, paleografía y notas por J. B. Warren), Morelia, Fimax Publicistas, 1997, p. 27.

6 A guisa de ejemplo, véase Quiroga, Vasco de, Información en derecho (introducción y notas de Carlos Herrejón Peredo), México, SEP, 1985.

7 Ecli 4,3-1.

8 "Bula de erección del obispado de Michoacán y carta jurídico-pastoral de don Vasco", en Comisión de Historia del 450 Aniversario (ed.), Vasco de Quiroga y obispado de Michoacán, Morelia, Fimax Publicistas, 1986, p. 19.

9 Quiroga, Vasco de, Información..., cit., I, 8. 
Este libro forma parte del acervo de la Biblioteca Jurídica Virtual del Instituto de Investigaciones Jurídicas de la UNAM

dos en su Información en derecho. Se puede decir plausiblemente que el oidor consideraba esa tríada como resultado de causas dispares, pero conectadas de modo determinante con la avaricia y la violencia de los conquistadores y colonizadores ibéricos.

\section{Dispersión}

Ya desde el primer documento quiroguiano que poseemos, o sea, la "Carta al Consejo de Indias", 10 escrito a escasos siete meses de su llegada a la Nueva España, el oidor consignó el fenómeno de la "dispersión" de los naturales, los cuales "...biven tan derramados sin orden ni concierto", ${ }^{11}$ huyendo de la servidumbre y de las violencias que, de distinto modo, ejercían contra ellos los conquistadores. En su Información, el oidor precisa que “...por no se fiar de nosotros ni de nuestra mala jacilla e conversación que tenemos, les viene el huir y alzarse a los montes por evitar los daños...". ${ }^{12}$ Las consecuencias de este lastimoso fenómeno no se hicieron esperar: descenso poblacional, desarticulación social, pobreza e indefensión de los antiguos habitantes de la que comenzó a ser llamada la Nueva España.

Esta dispersión o "derramamiento" de los vencidos debió haber chocado frontalmente con la mentalidad de un hombre que, a juicio de B. Warren, estuvo familiarizado con la alta urbanización de su patria de origen ${ }^{13}$ y, además, con la antropología filosófi-

10 Quiroga, Vasco de, "Carta al Consejo de Indias”, en Aguayo Spencer, R., Don Vasco de Quiroga, taumaturgo de la organización social. Seguido de un apéndice documental, México, Oasis, 1970, pp. 77-83.

11 Ibidem, p. 79. Motolinía consigna también el mismo fenómeno y, a su vez, lo explica como consecuencia del sistema de minas. Véanse Benavente, Toribio de, Historia de los indios de la Nueva España (estudio crítico, apéndices, notas e índices de E. O’Gorman), México, Porrúa, 1973, p. 17; id., Memoriales (edición crítica, notas e introducción de N. J. Dyer), México, Colmex, 1996, p. 144.

12 Quiroga, Vasco de, Información..., cit., II, 14. Véase también los numerales III, 3, 21, 31, etcétera.

13 Warren, F. B., "Vasco de Quiroga, fundador de hospitales y colegios", Missionalia Hispanica, núm. 67, 1966, p. 45. 
Este libro forma parte del acervo de la Biblioteca Jurídica Virtual del Instituto de Investigaciones Jurídicas de la UNAM

ca de Aristóteles, recibida por Quiroga a través de un personaje a quien él equivocadamente llama "Cirilo". Es sabido que para Aristóteles el hombre es por naturaleza un ser irrenunciablemente "político" (zôon politikón), y, por lo mismo, la pólis o la sociedad es el espacio insustituible para su humanización y desarrollo: “...el que huye de la sociedad, se lee en el texto recibido, o es un loco rabioso o un ermitaño; mas el ermitaño en realidad no huye, pues se asocia con los dioses". ${ }^{14}$

Se ha de notar que sin estos presupuestos histórico-filosóficos sería difícil explicar tanto la repulsa ética de las causas de la "dispersión" de los naturales como la gestación mental y la realización de los hospitales-pueblo de nuestro autor.

\section{Despoblación}

Este terrible fenómeno poblacional tuvo tres causas principales: la guerra, el mortífero sistema de minas y de encomiendas, y las epidemias. ${ }^{15}$ Silenciando incomprensiblemente el tiránico y nefasto sistema de encomiendas, ${ }^{16}$ Quiroga concentra su discurso en la denuncia al sistema de las minas, a las cuales da califica-

14 Quiroga, Vasco de, Información..., cit., 36; Aristóteles, Política, lib. I, 1253a. Nótese que la disyuntiva en Aristóteles es más extrema, pues no se da entre un loco y un ermitaño, como en el texto "recibido" por Quiroga, sino entre una bestia (therion) y un dios (Theós).

15 Para esta discutida cuestión, véase el análisis que realizó Gustavo Gutiérrez sobre los trabajos clásicos (W. Borah, Sh. F. Cook) y más recientes (Sánchez Albornoz y E. Maeder). Cfr. Gutiérrez, Gustavo, En busca de los pobres de Jesucristo. El pensamiento de Bartolomé de las Casas, Salamanca, Sígueme, 1993, pp. 651-655.

16 La perjudicial interconexión entre el sistema de minas y el de las encomiendas ha sido reconocida por autores de distinta procedencia, así como la explotación y opresión de los naturales en las encomiendas, las cuales "interesaban a los españoles como fuente de aprovisionamiento para las minas... Les proveían de maíz, frijol y otras cosas necesarias... También proveían de cargadores". Cfr. Warren, J. B., Vasco de Quiroga y sus hospitales-pueblo de Santa Fe, Morelia, UMSH, 1977, p. 106; Paredes, G., "El tributo indígena en la región del lago de Pátzcuaro", en Varios autores, Michoacán en el siglo XVI, Morelia, Fimax Publicistas, 1984, p. 26; Zavala, S., De encomiendas y propiedad territorial en algunas regiones de la América española, México, Robredo, 1940. 
Este libro forma parte del acervo de la Biblioteca Jurídica Virtual del Instituto de Investigaciones Jurídicas de la UNAM

tivos merecidamente infamantes: buitreras, ${ }^{17}$ infierno, ${ }^{18}$ sepulturas. ${ }^{19}$ Mediante esta metafórica, el oidor señala su efecto humana y cristianamente más inaceptable: las muertes anticipadas de los naturales. Coincidiendo con Las Casas, Motolinía y otros misioneros en fondo y forma, ${ }^{20}$ Quiroga mostró que el discurso compasivo o misericordioso no es un discurso débil ni está reñido con la denuncia sin concesiones; además, devela y debela la ambición de los mineros y la realidad de las minas: lugar del horror y del exterminio en donde los naturales fenecen de "una muerte muy desesperada, muy cierta y temprana";21 en donde "muy en breve mueren de mala muerte, y vivan muriendo y mueran viviendo como desesperados", ${ }^{22}$ y en donde "pocos duran tres años, cuanto más cinco". ${ }^{23}$

El minorita Toribio de Benavente (Motolinía) corrobora a su manera la información y valoración quiroguianas del sistema colonial de minas:

La nona plaga fue el seruiçio de las minas, a las quales de sesenta y setenta leguas y avn más lejos los indios cargados yban con mantenimientos e la comida para si mesmos lleuauan a vnos se les acababa en llegando a las minas, a otros en el camino de vuelta antes de su casa. A otros detenían los mineros algunos días para que les ayudasen a descupetar o los ocupaban en hazer casas y seruirse dellos a do acabada la comida, o se morían en las minas o por el camino... Otros volvían tales que no podían escapar pero

17 Quiroga, Vasco de, Información..., cit., II, 4.

18 Ibidem, I, 8.

19 Ibidem, III, 36 y 66.

20 Domingo de Santo Tomás, Las Casas y Motolinía se cuentan entre ellos; pero el caso de Motolinía es del todo singular, pues si, por un lado, lamenta la destrucción y la despoblación, así como la muerte de tantos indios que no se podrían contar, consideraba, por otro lado, este hecho como la sesta plaga; es decir, como un castigo que Dios les había mandado a causa de su idolatría. Véase Benavente, Toribio de, Memoriales..., cit., p. 142.

21 Quiroga, Vasco de, Información..., cit., III, 170.

22 Ibidem, III, 57.

23 Ibidem, III, 220. 
Este libro forma parte del acervo de la Biblioteca Jurídica Virtual del Instituto de Investigaciones Jurídicas de la UNAM

destos y de los esclauos que en las minas murieron fue tanto el hedor que causó pestilencia en especial en las minas de Huaxyacac en las cuales media legua alrededor y mucha parte del camino apenas pisauan sino sobre muertos o huesos. E eran tantas las auras e cuervos que venían a comer los cuerpos muertos e dauan çebados en aquella cruel carniçería que hazían sombra al sol. ${ }^{24}$

Por lo que toca al sistema de encomiendas, el caso de fray Bartolomé es digno de mención, pues a diferencia de Quiroga y de los frailes de la Nueva España, el dominico consideraba que la despoblación que se estaba dando en las islas también tenía como causa la tiranía de la encomienda. En efecto, en una "Carta al Consejo", escrita como la de Quiroga en 1531, Bartolomé decía a sus miembros lo siguiente:

El remedio, señores, de esta isla y de estas otras está muy claro, y se ha acá muy bien pensado, y todos conocen que es éste: que se liberten los indios, y se sacar de poder los cristianos, porque padecen, como han padecido cruel tiranía; y ésta es la que estas islas ha totalmente despoblado; y puestos en pueblos donde ellos quisieren estar, con que ${ }^{25}$ estén en alguna cantidad juntos, y vivan y descansen sin dar tributo ninguno, porque harto lo han sudado. ${ }^{26}$

\section{Destrucción o "destruición"}

Quiroga, al igual que Las Casas y hasta H. Cortés, utiliza este concepto para dar cuenta de la devastación o destrucción de

24 Benavente, Toribio de, Memoriales..., cit., p. 144 (cursivas en el texto). También véanse Benavente, Toribio de, Historia de los indios..., cit., pp. 16 y 17; Quiroga, Vasco de, Información..., cit., III, 221.

25 El universo lexemático, del que forma parte el concepto "destrucción", ha sido ampliamente estudiado por Alain Milhou. Véase, por ejemplo, Milhou, Alain, "El concepto de «destrucción» en el evangelismo milenario franciscano", Actas del II Congreso Internacional sobre los franciscanos en el Nuevo Mundo (siglo XVI). La Rábida, 21-26 septiembre 1987, Madrid, Deimos, 1988, pp. 297-315.

26 Texto en Gutiérrez, Gustavo, En busca de los pobres de Fesucristo..., cit., p. 401, nota 19. 
Este libro forma parte del acervo de la Biblioteca Jurídica Virtual del Instituto de Investigaciones Jurídicas de la UNAM

la tierra, esquilmada de modo compulsivo por los colonizadores españoles. Quiroga advertía que “...si no se pusiera el freno que se puso a aquel desenfrenamiento de españoles..." habría el riesgo de "...destruición también de toda esta tierra, como lo fue en las Islas e Tierra Firme, si Dios no lo remedia por su piedad". ${ }^{27}$ En otros textos de su Información, Quiroga atestigua y denuncia el "poco cuidado" que los ibéricos tenían de la tierra, ${ }^{28}$ lo mismo que su proceder irresponsable, lo cual los convierte en "...los enemigos de la tierra... que no la quieren ni están en ella sino para destruir y esquilmar, y después la dejar perdida y buscar otra que destruir de nuevo...". ${ }^{29}$

Los tres fenómenos mencionados (dispersión, despoblación y destrucción), a juicio de Quiroga, eran el resultado necesario de la imposición de una lógica, por llamarla de alguna manera, dinamizada por la "codicia desenfrenada" de los colonizadores y por la priorización del "interese particular" sobre el bien común o el bien de la república, la cual produjo "por necesidad" una concentración de la riqueza en las manos de "cuatro o cinco mineros", 30 así como la pobreza de los "demás"31 y la miseria de los maceoales. En la denuncia de la "codicia" de los españoles coinciden Quiroga, Las Casas, Motolinía ${ }^{32}$ y otros protagonistas de la historia inicial del Nuevo Mundo, los cuales, siguiendo el pensar de algu-

27 Quiroga, Vasco de, Información..., cit., II, 4. También véase Quiroga, Vasco de, Información..., cit., III, 38 y 69. Sorprende que Cortés denuncie ese proceso y que lo haga prácticamente con la misma retórica. Los españoles - escribió el conquistador - se conducen "con esas tierras como se condujeron en las islas do las tierras fueron un botín: esquilmarlas, destruirlas y después dejarlas". Cfr. Cortés, Hernán, Cartas de relación, México, Porrúa, 1993, p. 205.

28 Quiroga, Vasco de, Información..., cit., III, 61.

29 Ibidem, III, 69.

30 Ibidem, III, 224.

31 Ibidem, I, 4, 221 y 223. Para verificar la presencia de la dialéctica "riqueza de pocos-pobreza de muchos" en Moro, san Basilio y san Gregorio de N., véase González Cruz, M., Teología de la misericordia, implícita en los escritos y en la praxis de Vasco de Quiroga, México, UPM, 2012, p. 187, nota 385.

32 Benavente, Toribio de, Memoriales..., cit., p. 142. Para un análisis del pensamiento de Las Casas sobre la avaricia/codicia como idolatría, véase Gutié- 
Este libro forma parte del acervo de la Biblioteca Jurídica Virtual del Instituto de Investigaciones Jurídicas de la UNAM

nos escritores de la época clásica, pero también el de Pablo y el de algunos padres de la Iglesia, la consideraban como la raíz de todos los males ${ }^{33}$ y como una forma de idolatría. Para ilustrar esto basta con ver el siguiente texto quiroguiano:

...siendo cosa muy cierta que todo hombre muy amigo de su interese ha de ser de necesidad enemigo della (la república), y por el contrario. Pero no me maravillo: "Pues la avaricia, como dice sancto Ambrosio", es una ceguera y hasta acarrea desviaciones en la religión. Digo, pues, que la codicia es ciega; mas se oculta con diversas artimañas y fraudes. El avaro no mira lo que pertenece a la divinidad, sino discurre lo que atañe a su ambición. Pues aun cuando sea rico, siempre anda buscando en dónde tener más y más, no importa que sea por senderos torcidos. La codicia es una gran mal; incluso el origen de todos los males. Esto dice Ambrosio. ${ }^{34}$

\section{LA RESPUESTA DE QUIROGA: LOS HOSPITALES-PUEBLO}

La respuesta práctica que Quiroga pensó y desarrolló para remediar la dramática situación de los vencidos, particularmente la de los que él llama maceoales, se concentró principalmente en sus hospitales de Santa Fe, singular proyecto de antecedentes lejanos que conviene esclarecer.

rrez, Gustavo, En busca de los pobres de fesucristo..., cit., pp. 257-262; id., Dios o el oro de las Indias, Salamanca, Sígueme, 1990, pp. 137-150.

33 Finkenrath hace notar que Demócrito y otros filósofos griegos estimaban a la codicia/avaricia como "la metrópoli de todo lo malo". Los humanistas leídos por Quiroga, como Moro y Budé, la consideraban al mismo nivel que la soberbia, es decir, como raíz de los males sociales. Véase González Cruz, M., Teología de la misericordia..., cit., p. 180, nota 171.

34 Quiroga, Vasco de, Información..., cit., III, 223 (cursivas en el texto); III, 72, 179. Para un desarrollo más amplio del tema y para precisar la autoría del texto que Quiroga atribuye a san Ambrosio, pero que, en realidad, pertenece a Máximo de Turín, véase González Cruz, M., Teología de la misericordia..., cit., pp. 175-181, nota 372 . 
Este libro forma parte del acervo de la Biblioteca Jurídica Virtual del Instituto de Investigaciones Jurídicas de la UNAM

Es cierto que el mismo Quiroga, en su Información en derecho, confiesa la influencia directa e inmediata que, en el diseño de su proyecto hospitalario, ejerció un escrito del canciller inglés Thomas More, intitulado Utopía. Este exitoso escrito inspiró la urbanística donde se habría de implantar la que podría denominarse "política quiroguiana de la hospitalidad", la cual debía realizar las siguientes prioridades: la conservación de los naturales y de la tierra; la conversión de los mismos, y la adquisición de "una doble policía": la espiritual-cristiana y la social. Vasco los pensó como complejos urbanísticos "familiares" donde los maceoales, viviendo "políticamente", podrían llegar a ser bastantes y, de ese modo, lograr una existencia eudaimónica-cristiana.

Se ha de decir, sin embargo, que la fuente inspiradora de este singular proyecto no se agota en More, sino que implica el ya mencionado sustrato antropológico aristotélico, la doctrina cínico-estoica de la autárkeia, la práctica hospitalaria antigua y medieval - particularmente la de la Orden de San Juan de Jerusalén, de la que fue miembro-, y una experiencia tan lejana como poco conocida: la Basiliades o kainè pólis fundada por san Basilio de Cesarea, de quien se hablará más adelante. En este caso, a diferencia de los otros, no hay modo de establecer un nexo causal entre ambas realizaciones, pues hasta ahora no se puede ofrecer una base documental que lo evidencie. No obstante ese vacío, la conexión con la kainè pólis ha de tomarse al menos como un importante antecedente histórico del proyecto quiroguiano.

\section{La práctica hospitalaria en la antigüedad cristiana}

Los estudiosos de la historia de la hospitalidad y del hospital han hecho notar la ambigüedad semántica de este último término, así como la univocidad de su uso actual. En efecto, el vocablo "hospital" remite hoy en día de modo automático a una estructura sanitaria para enfermos. En la antigüedad cristiana, en coherencia con su raíz etimológica (hospes), la palabra se identificaba simplemente como una estructura arquitectónica donde 
Este libro forma parte del acervo de la Biblioteca Jurídica Virtual del Instituto de Investigaciones Jurídicas de la UNAM

se atendían "huéspedes", sin precisar ni sus condiciones de salud ni otras peculiaridades. La nomenclatura con la que se les designaba en ese entonces expresaba ya la amplitud y la diversidad de servicios que se otorgaban dentro de lo que se identificaba de modo genérico con el término "hospital". Crislip, además de mencionar el vocablo obvio - nosokomeion ("place for the care of sick")- - enumera los siguientes: xenodocheion o xenón ("a hostel for strangers"); ptochotropeion ("a place for the nourrishment of poor"); orphanotropeion ("for orphans"); gerontokomeion ("for the Elderly"), y keluphokomeion o lobwtropheîn ("for lepers"). Este autor advierte que "These various terms do not generally distinguish different types of institutions. In later Byzantium, for instance, nosokomeion and xenon were entirely interchangeable". ${ }^{35}$

Considerando lo anterior, los beneficiarios de la red hospitalaria de la antigüedad cristiana - desarrollada en el Medio Oriente durante la segunda mitad del siglo IV, al amparo y protección de los eremitas de las lauras ${ }^{36}$ y los cenobios - no eran sólo los enfermos, sino también los transeúntes, los pobres, los huérfanos, las viudas, los viejos y los niños; en pocas palabras: los más vulnerables de las sociedades de entonces, sobre todo las greco-romanas. Crislip puntualiza que los beneficiarios de la hospitalidad cristiana, y de las acciones caritativo-compasivas de los cristianos de los primeros siglos, eran lo mismo los ptochoi que los pénetoi, que siendo pobres, no lo eran en la misma medida que los primeros. ${ }^{37}$ Sin intención de contradecir el dato de la amplia constelación de servicios vinculados al hospital del siglo IV, considerado hospitale

35 Crislip, A. T., From Monastery to Hospital. Christian Monasticism \& the Transformation of Health Care in Late Antiquity, Ann Arbor, UMP, 2005, p. 102 (cursivas en el texto).

36 Las "lauras" (del griego layra, calleja/corredor) eran un conjunto de celdas individuales o "the row of houses set along a street". Para el tema, véanse Mara, M. G., "Laura", en Bernardino, A. di (dir.), Diccionario patrístico de la antigüedad cristiana II, Salamanca, Sígueme, 1998, p. 46; Crislip, A. T., op. cit., p. 4.

37 Aquí, según Crislip, se evidencia una diferencia fundamental con el cuidado que brindaba la Antigüedad greco-romana a su población vulnerable: "...this aid was only intended for the relatively poor, the penês, and not for the truly destitute, ptôchos". Crislip, A. T., op. cit., p. 47. 
Este libro forma parte del acervo de la Biblioteca Jurídica Virtual del Instituto de Investigaciones Jurídicas de la UNAM

pauperum et peregrinorum, Crislip recalca que "...medical care was regarded as the most remarkable activity of the hospital and its sine qua non". ${ }^{38}$

\section{El hospital medieval}

Con plena seguridad se puede dar por asentado que los antecedentes inmediatos del proyecto hospitalario de Quiroga se localizan en la praxis medieval de la hospitalidad y que, a grandes rasgos, ésta se seguía pensando y practicando en los mismos términos en que fue pensada y practicada a partir de la segunda mitad del siglo IV. En efecto, la hospitalidad y el hospital continuaban siendo considerados como frutos maduros de la misericordia cristiana (insigne et eximium opus misericordiae, llamaba al hospital un obispo del siglo IX de nombre Jonás) y como espacio propio para la práctica de otras obras de misericordia. En consecuencia, en el hospital medieval no sólo se atendía a los enfermos, sino también a los itinerantes y al multiforme universo de los pobres. ${ }^{39}$

M. Mollat, utilizando una criteriología más bien heteróclita, nos ha proporcionado una taxonomía pormenorizada de los pobres de la Edad Media. Los nombres con los que eran designados forman una abigarrada constelación que nos permite acercarnos a la amplitud y variedad de la pobreza medieval. El pobre de ese tiempo era tipificado como egens, egenus, indigens, inops, insufficiens, miser; esuriens, famelicus; nudus, pannosus; caecus, claudus, contractus, infirmus, leprosus, vulneratus, aegrotans, debilis, senex, valetudinarius; idiotus, imbecillis, simplex; orphanus, vidua; exiliatus, banus; miserabils, miserabilis persona, etcétera. ${ }^{40}$ Una pobreza tan amplia y diversificada requería una atención abarcadora y generosa.

38 Ibidem, p. 102.

39 Para esta cuestión, véanse Windemuth, M. L., Das Hospital als Träger der Armen Fürsorge im Mittelalter, Stuttgart, Steiner, 1995; Jetter, D., Das europäische Hospital von der Spätantike bis 1800, Köln, DuMont, 1986; Imbert, Jean (dir.), op. cit.

40 Mollat, M., Les pauvres au Moyen Âge. Étude sociale, París, Hachette, 1978, pp. 11 y 12; id., "Les premiers hôpitaux. VI-XI siècle", en Imbert, Jean (dir.), Histoire 
Este libro forma parte del acervo de la Biblioteca Jurídica Virtual del Instituto de Investigaciones Jurídicas de la UNAM

El surgimiento y el desarrollo espectacular que, sobre todo en el siglo XII, experimentaron estas instituciones caritativas no estuvieron dinamizados por el vigor de un espíritu filantrópico de cuño estoico, sino más bien por el imperativo ético-teológico de la misericordia explícitamente planteado por Jesús, ${ }^{41}$ así como por las exigencias derivadas de la autoidentificación de Cristo con el pobre, el desnudo, el hambriento, el sediento, el encarcelado y el enfermo. ${ }^{42}$ Fórmulas estereotípicas como in peregrino Christus, Christum in hospitibus recipere, pauperes Christi, vicarii Christi, nuestros señores los enfermos, expresan tanto la comprensión cristológica del necesitado como la motivación mimética para atenderlo en sus necesidades.

La multiplicación de los hospitales en la Edad Media se explica básicamente por dos factores: en primer término, el incremento creciente de las necesidades y de los necesitados o pobres, y en segundo término, por la gran diversidad de los interesados en su fundación. Es cierto que el aumento de los pobres en la Edad Media no se puede representar con una línea ascendente, pues hubo épocas de un crecimiento económico significativo, en las cuales el multiforme fenómeno de la pobreza parecía haber "detenido" su escalada. ${ }^{43}$ Sin embargo, la pobreza representó un fenómeno más bien constante y diversificado, ligado de modo etiológico a factores tan disimétricos, como las guerras, las epidemias y, no en último lugar, el ideológico concepto de "orden social", conforme al cual se pensaba que "Dios debiera haber dado la riqueza a todos

des hôpitaux en France, Toulouse, Privat, 1982, p. 15; Lindgren, U., "Hospital", Lexikon des Mittelalters, Múnich, DTV, 2003, vol. V, col. 133.

41 Lc 6,36.

42 Mt 25.

43 Algunos autores consideran que el siglo XII fue una época de crecimiento poblacional y económico; por el contrario, otros advierten la vigencia de un pensar fatalista, según el cual el orden social era inmutable y había sido determinado por Dios mismo. Conforme a este pensar, "la pobreza era un componente normal de la vida humana". Véanse Verger, J., La renaissance du XIIe siècle, París, Cerf, 1999, pp. 39-55; Mollat, M., Les pauvres au Moyen Âge..., cit., p. 61. 
Este libro forma parte del acervo de la Biblioteca Jurídica Virtual del Instituto de Investigaciones Jurídicas de la UNAM

los hombres, pero ha querido que haya pobres para que los ricos tuviesen ocasión de redimir sus pecados". ${ }^{44}$

La conjunción de estos y otros elementos explica la que M. Mollat denomina "floración de los hospitales" (siglo XII), en los que se concentraba la práctica de las obras de misericordia, en cuya multiplicación se interesaron no sólo obispos, ${ }^{45}$ sino también órdenes religiosas, establecidas o nuevas, y laicos, con frecuencia asociados en cofradías. Atestigua esta floración - discutible algunas veces en sus formas y en sus intenciones - lo mismo los hospitales más bien modestos que los que impresionan todavía hoy tanto por sus dimensiones físicas como por la variedad y especialización de servicios que ofrecían. Tal es el caso de los hospitales fundados y dirigidos por la Orden de San Juan de Jerusalén.

M. Mollat considera que los estatutos y reglas de esta Orden ejercieron una enorme influencia en "...infinité d'hôpitaux en ce qui concerne la conception de l'hospitalité, la considération des malades, leur accueil et leurs soins". ${ }^{46}$ Otros autores han insistido en la grandiosa dimensión arquitectónica de los hospitales de esa Orden, los cuales influenciaron grandes proyectos hospitalarios surgidos también de la compasión cristiana. Berthold WaldsteinWartenberg, tomando como fuente los datos arqueológicos de Konrad Schik, obtenidos hacia 1900, y los relatos de un monje alemán de nombre Johann von Würzburg, quien visitó Jerusalén hacia 1165, ha "reconstruido" el hospital que la Orden de San

44 Texto en Geremek, B., La piedad y la horca. Historia de la miseriay de la caridad en Europa, Madrid, Alianza, 1989, p. 28.

45 Autores recientes nos recuerdan que desde la Antigüedad, el obispo era considerado pater pauperum et defensor civitatis si actuaba misericordiosamente, o, en caso contrario, neccator pauperum. Además, el cuidado de los pobres venía siendo exigido por sínodos y concilios, como el de Toledo (633), cuyo canon 33 establecía que "los obispos no rehúsen el cuidado que Dios les ha impuesto de proteger y defender al pueblo... Y si algún obispo descuida esto, sea reo ante el concilio". Texto en González Faus, J. I., Vicarios de Cristo, p. 101. También véanse Mollat, M., Die Armen im Mittelalter, Múnich, 1984, pp. 42-45; id., "Les premiers hôpitaux. VI-XI siècle", op. cit., p. 15.

46 Mollat, M., "Floraison de fondations hospitalières, XIIe et XIIIe siècles", en Imbert, Jean (dir.), Histoire des hôpitaux en France, Toulouse, Privat, 1982, p. 59. 
Este libro forma parte del acervo de la Biblioteca Jurídica Virtual del Instituto de Investigaciones Jurídicas de la UNAM

Juan de Jerusalén construyó en esa ciudad en el siglo XII. Ese espacio arquitectónico habría estado compuesto por varias salas, construidas en torno a la Iglesia de San Juan y a la del Convento Santa María latina. La primera de ellas estaba dividida en cuatro naves, de 80 metros de largo por 40 de ancho y 6 de alto; una segunda, de dos naves, medía 20 metros de largo y 18 de ancho. Berthold habla de una sala todavía mayor, la cual alcanzaba los 140 metros de largo y 120 de ancho, dividida en diez naves, que a su vez se encontraban subdivididas por cortinas.

Este complejo arquitectónico estuvo pensado para acoger a los peregrinos que visitaban la Ciudad Santa y para la atención a los enfermos y necesitados, sin distinguir si eran cristianos judíos o musulmanes, pues todos eran considerados un "Nächster Christi”. Según datos del monje alemán, 2,000 enfermos fueron atendidos por miembros de la Orden de San Juan en el tiempo en que él se encontraba in situ. ${ }^{47}$

La mística de la misericordia, que en los comienzos orientó las actividades de la Orden, se tornó compleja, ya que al adquirir muy tempranamente el estatuto de Orden Caballeresca (siglo XII), sus miembros, "hommes de fer et de foi", ${ }^{48}$ hubieron de armonizarla con el uso de las armas para defender ya no sólo a los débiles o pequeños (elachístoi), como lo exigía el espíritu caballeresco medieval, sino también "al occidente cristiano", amenazado por los sarracenos que ya habían ocupado los "lugares santos".

En la lógica de la espiritualidad de los primeros miembros de la Orden de San Juan, los enfermos, al igual que las otras categorías de "necesitados" nombrados en el Evangelio, ${ }^{49}$ también eran identificados con Cristo, y en consecuencia eran nominados

47 Para los datos, véanse Waldstein-Wartenberg, Berthold, Die Vasallen Christi. Kulturgeschichte des fohanniterordens im Mittelalter, Viena, Böhlau, 1988, pp. 97-39, en especial pp. 107-109; Windemuth, M. L., op. cit., pp. 66-74, especialmente pp. 69 y 70 .

48 Galimard Flavigny, Bertrand, Les Chevaliers de Malte. Des hommes de fer et de foi, París, Gallimard, 2007.

49 Mt 25. 
Este libro forma parte del acervo de la Biblioteca Jurídica Virtual del Instituto de Investigaciones Jurídicas de la UNAM

con una sorprendente fórmula "señorial": "nuestros señores los enfermos". Este modo de verlos y nombrarlos aclara su enorme, profesional, eficaz y caritativa dedicación al cuidado de los enfermos y a la causa de los débiles o insignificantes. Esto representa la "otra cara" de su mística cristológica, la cual impulsa a actuar de modo misericordioso y compasivo, como lo hizo Jesús cuando encontraba a personas en situación de peculiar necesidad. Quiroga, un miembro de esa Orden, formuló esta dimensión performativa de la mística de la misericordia con un lacónico y programático "...yendo a ellos como Cristo vino a nosotros". ${ }^{50}$

Estos tres elementos - la grandiosidad de los hospitales fundados por la Orden de San Juan, la defensa de los débiles y la enorme consideración para con los enfermos - han de tomarse como antecedentes y elementos inspiradores de la obra hospitalaria que Quiroga realizó en los inicios mismos de la historia de la Nueva España.

\section{LOS HOSPITALES-PUEBLO, ¿UNA KAINE PÓLIS NOVOHISPANA?}

El lastimoso espectáculo que, a través del tiempo y en todas partes, han ofrecido las masas de desposeídos ha impactado las conciencias de los mejores y les ha impulsado a buscar soluciones. Es cierto que, por razones ya aquí mencionadas, antes de la Edad Moderna nunca se planteó la cuestión de la supresión de la multiforme pobreza, antes bien se le justificó con argumentos de diversa índole, incluidos los teológicos. Sin embargo, se ha de decir también que hubo personajes que no se contentaron con la práctica establecida de las tradicionales obras de misericordia, sino que trataron de poner remedio puntual a la calamitosa situación de una buena parte de los que vivían al margen de los mínimos del bienestar. Basilio el Grande y Vasco de Quiroga han de contarse entre ellos.

50 Quiroga, Vasco de, Información..., cit., III, 3. 
Este libro forma parte del acervo de la Biblioteca Jurídica Virtual del Instituto de Investigaciones Jurídicas de la UNAM

\section{Basilio y el contexto socioeclesial de su Basiliades}

Estudiosos recientes de la persona y de la obra de san Basilio de Cesarea han trazado las coordenadas histórico-sociales y eclesiales en que este obispo ejerció su ministerio episcopal. Su tiempo se singularizó por factores disímiles: la superación de la terrible fase de persecuciones emprendidas contra el cristianismo y su establecimiento como religión oficial del Imperio romano; las luchas cristológicas desatadas por Arrio; la celebración del primer concilio ecuménico en Nicea (325); la aparición y desarrollo de movimientos heréticos de índole distinta. Estos factores fueron sincrónicos con eventos político-sociales y culturales, como el derrumbe del mundo antiguo, epitomizado en la persona del emperador Juliano, ${ }^{51}$ o las terribles crisis sociales y económicas que produjeron el empobrecimiento y una devastadora hambruna en muchas regiones del Imperio romano, entre ellas la de Capadocia. ${ }^{52}$ Gregorio Nacianceno, en su Eis tòn mégan Basíleion epitáphios (Oración fúnebre en honor del gran Basilio), se refiere "a ella de modo más bien sobrio": "Il y avait une famine, la plus dure de mémoire d'homme. La ville suffrait: d'assitance, il n'en venait de nulle parte, et le fléau était sans remède". ${ }^{53}$

51 "Das Vierte Jahrhundert ist kirchen- sowie profangeschichtlich gekennzeichnet vor allem von der Zerfall der antiken Welt. Wie gesagt, fand diese Entwicklung in ihrem Endstadium seine Höhepunkt in der Person Kaisers Julian". Bonis, K. G., "Basilios von Caesarea und die Organisation der christlichen Kirche in vierten Jahrhundert", en Fedwick, P. J. (ed.), Basil of Caesarea: Christian, Humanist, Ascetic. A Sixteen-Hundredth Anniversary Symposium, Roma, PIMS, 1981, p. 308.

52 Saint Basile, "Lettre a Eusèbe, évêque de Samosata (Lettre XXVII) et Lettre a Eusébonas, évêque (L. XXXI)", en Saint Basile, Lettres, trad. de Y. Courtonne, París, Les Belles Lettres, 1957, t. I, pp. 65 y 73.

53 Nacianceno, Gregorio, Eis tòn mégan Basíleion epitáphios (Pour le grand Basile. Oraison funèbre) (introduction, texte critique, traduction et notes par J. Bernardi), París, Cerf, 1992, p. 201. También véase Karayannopoulos, I., "St. Basil's Social Activity: Principles and Praxis", en Fedwick, P. J., Basil of Caesarea: Christian, Humanist, Ascetic. A Sixteen-Hundredth Anniversary Symposium, Roma, PIMS, 1981, p. 375 . 
Este libro forma parte del acervo de la Biblioteca Jurídica Virtual del Instituto de Investigaciones Jurídicas de la UNAM

Basilio, siendo todavía presbítero de la Iglesia de Cesarea, llevó a cabo una serie de acciones evergéticas que tuvieron como beneficiarios principales a los huérfanos, la viudas, los transeúntes, los enfermos, etcétera, o sea, a aquellas personas que la tradición medio-oriental y judía consideraban objeto de compasión y de asistencia caritativa. ${ }^{54} \mathrm{En}$ un tiempo de penurias tan extremas que con frecuencia los padres de familia se veían obligados a vender a sus hijos, ${ }^{55}$ el ya obispo Basilio cristalizó en su persona la importante función de ser pater pauperum et defensor civitatis, ${ }^{56}$ pues, como consigna I. Karayannopoulos, él "...fully assumes the role of the caretaker, protector, mediator and defender of his diocese and his flock". ${ }^{57}$

De cierto, esta implicación a favor de los necesitados (ptochoi) no distingue a Basilio de otros grandes defensores de los miserables del siglo IV. Lo que realmente lo singulariza fue la realización de una pólis, conocida como kainè pólis o Basiliades, que se construyó en las cercanías de Cesarea para atender a las múltiples necesidades de los ptochoi. En este desarrollo urbanístico, Eusebio practicó un tipo de hospitalidad "estable" y, por tanto, distinta de la hospitalidad puntual que ordinariamente se dispensaba a transeúntes (peregrinos, viajeros) y a enfermos en otras instituciones hospitalarias, como la domus episcopalis, y, con eficacia envidiable, en las lauras y cenobios. Basilio, en cambio, planeó y edificó una verdadera ciudad, en la que se practicaba la hospitalidad de modo prolongado y diversificado, pero sin marginar la que podríamos

54 Para el tema, véanse Fensham, F. C., "Widow, Orphan, and the Poor in Ancient Near Eastern. Legal and Wisdom Literature", Fournal of Near Eastern Studies, vol. 21, 1962, pp. 129-139; Crislip, A. T., op. cit., pp. 50 y 51.

55 Basilio, en su Homilía 6. Contra la riqueza (Lc 12,16), nos ha dejado una descripción impresionante de un hecho que debió ser frecuente en un tiempo de concentración de la riqueza y de multiplicación de la pobreza. Véase PG 31 , pp. 262-278.

56 "And indeed, as L. Harmand has observed, very early the Church and her leaders were compelled to undertake the role of the Mediator and defender of the city or their region...". Karayannopoulos, I., op. cit., p. 377.

57 Idem. 
Este libro forma parte del acervo de la Biblioteca Jurídica Virtual del Instituto de Investigaciones Jurídicas de la UNAM

llamar "práctica ordinaria" de la misma. ${ }^{58}$ Dos principios teológicos guiaron a Basilio, conocido con razón como "el Grande", en la fundación y guía de su Basiliades: la gloria de Dios (eis mían dóxan toû Theoû) y la imitación de Cristo (Christoû mímesis), quien no sentía compasión y misericordia para con los enfermos y necesitados ni sólo los consolaba con su palabra, sino que los curaba y, a su vez, aliviaba algunas de sus necesidades. ${ }^{59}$ De ese modo, Basilio cumplimentó las dos condiciones inseparables de la misericordia cristiana: el sentimiento y la acción.

No obstante la grandiosidad que debió haber tenido la kainè pólis, encomiásticamente descrita por Gregorio Nacianceno, ${ }^{60}$ no se ha identificado con precisión el sitio donde fue erigida ni se tiene en la actualidad una descripción detallada de la misma. ${ }^{61} \mathrm{La}$ información más detallada proviene de una carta que el obispo de Cesarea dirigió en 370 al gobernador Elías, la cual nos permite conocer la intención que lo guió en la construcción de su Basiliades y su complejidad arquitectónica. Se trata de un documento de tipo apologético, en el que Basilio defiende su proyecto urbanístico y la orientación ético-social que le mereció ser considerado por el ya citado Gregorio como "almacén de la piedad" (tò tês eusebeías tameîn). ${ }^{62}$ En la parte que nos interesa reproducir, Basilio escribía:

58 Nacianceno, Gregorio, op. cit., pp. 261-265. Sobre el tema de las influencias y los modelos que siguió Basilio se ha discutido mucho. Las posiciones que, al respecto, desarrollaron autores como S. Giet en la primera mitad del siglo pasado han sido sometidas a juicio y contestadas por Crislip. Véanse Giet, S., Les idées et l'action sociales de Saint Basile, París, Gabalda, 1941, pp. 417-423; Crislip, A. T., op. cit.

59 Nacianceno, Gregorio, op. cit., p. 265.

60 Ibidem, pp. 261-265.

61 "We have no detailed description, however, of its architectural outlay and landscape, nor has the site been identified and excavate". Cfr. Crislip, A. T., op. cit., p. 105.

62 Nacianceno, Gregorio, op. cit., p. 262. También véanse Gain, B., L'Église de Capadoce au IV siècle d'après la correspondance de Basile de Césarée (330-379), Roma, PIO, 1985, p. 277; Giet, S., op. cit., p. 422. 
Este libro forma parte del acervo de la Biblioteca Jurídica Virtual del Instituto de Investigaciones Jurídicas de la UNAM

Sin embargo, yo pregunto a quienes halagan tus leales oídos, qué daño hacemos a la cosa pública, o qué interés común, pequeño o grande, es perjudicado por nuestra manera de administrar las Iglesias; a menos que se diga que menoscaba al Estado la construcción de una magnífica casa para elevar oraciones a nuestro Dios, rodeada de la noble casa del jefe y de otras, más sencillas, destinadas para los hombres dedicados al servicio divino. ¿A quién perjudicamos con la construcción de hospederías para los extranjeros que van de paso y para aquellos que, a causa de alguna enfermedad, tienen necesidad de cuidados, implantando ahí lo que es necesario para su alivio: enfermeros, médicos, bestias de carga y escoltas? Hubo necesidad de añadir también oficios que son necesarios para la vida y los que han sido inventados para asegurar una honorable existencia (euschémonos bios); además de (construir) otras casas, dispuestas para los trabajos, las cuales hermosean la localidad y (son motivo de) orgullo para nuestro gobernador, pues los elogios son para él. ${ }^{63}$

El texto basiliano nos permite concluir que la compleja iniciativa hospitalaria que se practicaba en la Basiliades implicaba el tradicional subvenir a las necesidades del transeúnte y/o del enfermo, pero lo superaba y lo diferenciaba por mucho. La intención de Basilio, en efecto, se extendió más allá de la atención transitoria a la amplia gama de los necesitados, ${ }^{64}$ pues, como se establece claramente en la carta, él creyó necesaria una hasta entonces inédita práctica de la compasión. ${ }^{65} \mathrm{~A}$ esta intención corresponde la implantación de talleres, en los que los residentes pobres de su "ciudad nueva" pudieron aprender y ejercer un oficio que les permitiera "llevar una vida digna o noble".

63 Basilio de C., "A Elie, gouverneur de la province", en Saint Basile, Lettres, trad. de Y. Courtonne, París, Les Belles Lettres, 1957, pp. 204-207 (cursivas y traducción del francés son mi responsabilidad).

64 Esta superación ya fue consignada por Giet (op. cit., pp. 417-423) y Gain (op. cit., pp. 277-289). Para una información más amplia y actual sobre este aspecto, véase Crislip, A. T., op. cit., pp. 103-120.

65 Los resultados de la discusión que sobre los antecedentes de la kainè pólis ocupó las mentes de algunos estudiosos del siglo pasado no convencen a Crislip. Con respecto a esta cuestión, véase Crislip, A. T., op. cit., pp. 127-133. 
Este libro forma parte del acervo de la Biblioteca Jurídica Virtual del Instituto de Investigaciones Jurídicas de la UNAM

En resumen, Basilio de Cesarea practicó la hospitalidad de modo diferenciado ${ }^{66}$ y ejemplar. Su kainè pólis o Basiliades fue el espacio en el que se ofreció seguridad al transeúnte, cuidados a los enfermos y, mediante la práctica de oficios manuales, una posibilidad de lograr una "vida digna" a los pobres (ptochoi) que la poblaron. Esta empresa no fue impulsada ni por la filantropía estoica ni por el sistema de patronazgo, ${ }^{67}$ sino por la compasión afectiva y efectiva, por la Christoû mímesis y únicamente para la gloria de Dios (eis mían dóxan toû Theoû). Pues bien, siglos más tarde, un letrado castellano proyectó y realizó en la Nueva España dos hospitalespueblo, en los que se practicó la hospitalidad con fines análogos: conservar, cristianizar y socializar a los más "desfavorecidos" por la conquista y la colonización, para que ellos lograran alcanzar una "vida suficiente y política".

\section{El oidor Vasco de Quiroga, fundador de hospitales-pueblo}

La idea de "reducir" a los naturales en "pueblos nuevos", "...donde trabajando y rompiendo la tierra, de su trabajo se mantengan (los indios)", no es originaria de Quiroga; es decir, no fue el primero en pensarla como "remedio" a la dispersión de los naturales. Paulino Castañeda ha puntualizado que "...para cuando Quiroga exponía su punto de vista, la idea de las reducciones era un clima de opinión y abundaban las cédulas reales". Además, continúa diciendo Paulino:

66 Crislip advierte esta diferenciación en los distintos nombres con los que el mismo Basilio identifica su "ciudad nueva": "Basil himself variously calls it as ptôchotropheion (poor house), a xenodocheion (hostel), and a katagôgion (rest house)...". Ibidem, p. 104.

67 Crislip señala que el cuidado de los necesitados de la Antigüedad tardía dependía de la familia, de la filantropía y del sistema de patronazgo. El cristianismo habría superado con creces este triple recurso, pues atendía el caso frecuente de los necesitados abandonados por sus familias; la atención era motivada por la misericordia, y no se regía ni por el principio de reciprocidad (los pobres no podían satisfacer este principio) ni por el del patronazgo, ya que ése suponía que entre el patrón y el cliente (el necesitado) no existía una diferencia tan abismal como la que de hecho se daba entre el patrón y los ptochoi. Ibidem, pp. 45-50. 
Este libro forma parte del acervo de la Biblioteca Jurídica Virtual del Instituto de Investigaciones Jurídicas de la UNAM

...acercándonos a las fechas del Informe de Quiroga, consta la solicitud de fray Juan de Zumárraga, para que «los pueblos se junten y estén policía y no derramados en montes y chozas, como bestias fieras...». Poco después insistía: «si se diese a estos naturales tan capaces de razón, manera de vivir en policía y oficios como en Castilla, juntando los pueblos y calles...». ${ }^{68}$

Nuestro personaje debió haber conocido las instrucciones de 1503 y 1513, así como las Leyes de Burgos (1512). Castañeda indica que en esa serie de documentos reales se disponía la creación de pueblos en los que fueran concentrados o reducidos los naturales para facilitar su conversión. A Quiroga le surgió la idea prácticamente a su llegada al Altiplano, ${ }^{69}$ pero, como consta en su Información en derecho (1535), esa idea se fue precisando en el lapso de cuatro años. En el escrito citado, redactado cuando ya estaba en obra el Hospital-Pueblo de Santa Fe de México (1532), hablaba de la necesidad de que se fundaran ciudades grandes "...donde se les puedan dar ordenanzas buenas, que sepan y entiendan y en que vivan, y se pueda tener cuenta y razón con ellos", ${ }^{70}$ las cuales habrían de organizarse siguiendo un modelo urbanístico inspirado en el Libellus vere aureus, a cargo de Tomás Moro. En las Ordenanzas de Santa Fe, escritas por Quiroga antes de 1547, quedaron reflejadas para siempre muchas de las ideas del humanista inglés.

Warren considera que la mejor descripción del Hospital de Santa Fe de México es debida al gobernador de Santiago Tlatelolco y Cayaluta, de nombre Juan, a quien debemos las siguientes noticias:

...desde hace pocos días, el Licenciado Quiroga les torno [a] hablar y decir que quería que más acá abajo, en una parte que se de-

68 Castañeda, Paulino, Don Vasco de Quiroga y su "Información en derecho", Madrid, Porrúa-Turanzas, 1974, pp. 108 y 109 (cursiva y comillas francesas en el texto).

69 Quiroga, Vasco de, "Carta al Consejo de Indias", op. cit., pp. 77-83.

70 Quiroga, Vasco de, Información..., cit., I, 20. 
Este libro forma parte del acervo de la Biblioteca Jurídica Virtual del Instituto de Investigaciones Jurídicas de la UNAM

cía Acasuchil, que ahora se dice Santa Fe, quería que le hiciesen dos casas, una los de México y otra los de Santiago, y que ellos y los de México, con sus maceguales, le hicieron al dicho licenciado cada uno de ellos una casa, que el dicho Licenciado les puso familia, que es con un patio pequeño y alrededor de casas pequeñas, y no más de una puerta por donde saliesen y entrasen, a manera de corrales; y que después de hechas estas dichas dichas (sic) dos casas familias, el dicho Licenciado los tornó a llamar y les dijo que le hiciesen otras dos casas, cada uno la suya, como las pasadas, sino que habían de ser mayores, y que ellos y los de México las hicieron por su mandado mayores que las primeras y mejores, y que en las primeras casas podían haber en cada una diez casillas, y en las segundas casas había quince casas pocas más o menos. ${ }^{71}$

El mismo Warren, glosando la declaración que Quiroga hizo con ocasión del juicio de residencia que se les practicó a los miembros de la Segunda Audiencia - él incluido-, refiere que estas construcciones fueron aumentadas con una "cocina amplia", dos iglesias, un refectorio (donde se llevaban a cabo las ocasionales comidas comunitarias) y otra "familia". ${ }^{72}$

Por las motivaciones ético-teológicas, por los trazos urbanísticos y por los beneficiarios, los hospitales-pueblo del oidor Quiroga, ciertamente, se pueden equiparar a la Basiliades o kainè pólis de Basilio. Efectivamente, ambas surgieron de exigencias éticas de la misericordia y de la compasión para con los necesitados, ${ }^{73}$ las cuales los impulsaron a ir más allá de la práctica puntual de ambas virtudes. Pero ni Basilio ni Quiroga limitaron sus iniciativas a brindar seguridad al transeúnte o prestar atención a los enfermos,

71 Para el texto, véase Quiroga, Vasco de, Ordenanzas de Santa Fe (introducción, paleografía y notas de J. B. Warren), Morelia, Fimax Publicistas, 1999, p. 24.

72 Warren, J. B., Vasco de Quiroga..., cit., p. 65. El término "familia", según Moreno y B. Warren, ha de tomarse por el edificio material o casa. Véase Quiroga, Vasco de, Ordenanzas..., cit., p. 95, nota 50.

73 Texto en Warren, J. B., "Apéndice II", en Warren, J. B., Vasco de Quiroga y sus hospitales-pueblo de Santa Fe, Morelia, UMSH, 1977, p. 183; Moreno, J. J., Fragmentos de la vida y virtudes de don Vasco de Quiroga (edición facsimilar y estudio introductorio de R. Alanís), Morelia, UMSH, 1998, p. 157. 
Este libro forma parte del acervo de la Biblioteca Jurídica Virtual del Instituto de Investigaciones Jurídicas de la UNAM

a los huérfanos, a las viudas, etcétera, sino que ambos idearon y ejecutaron un generoso proyecto urbano en el que, además de los servicios de caridad mencionados, se ofreciera a los más pobres de Cesarea y a los "indios pobres e miserables personas, pupilos viudas, huérfanos y mellizos"74 del Altiplano y Michoacán, los medios para ser/hacerse suficientes y "vivir sin necesidad", o en palabras de Basilio: "llevar una vida digna". Basilio y Quiroga convergen, pues, en las motivaciones, en las finalidades y en los medios para lograrlas: las primeras son, en ambos casos, estrictamente teológicas y no meramente filantrópicas; ${ }^{75}$ las segundas se expresan en las fórmulas ya mencionadas en este trabajo: lograr una vida digna (Basilio) y el cínico-estoico-quiroguiano "ser bastantes"; 76 finalmente, la Basiliades y los pueblos-hospitales fueron los medios a los que recurrieron para cristalizar sus motivaciones y finalidades.

No obstante, si quisiéramos ampliar más las informaciones sobre la base teológica de Quiroga, es menester explicitar sus intenciones reformadoras y su comprensión del hospital como lugar donde se practicaran todas las obras de misericordia. Respecto a lo primero, nuestro personaje pensó sus hospitales como una estructura social que ayudara a la conversión y conservación de la fe de los naturales, para de ese modo colaborar en la reforma y renovación de una Iglesia que él considera senescente. ${ }^{77}$ Este

74 Quiroga, Vasco de, Testamento..., cit., p. 27.

75 Crislip considera que la práctica de la filantropía greco-romana era selectiva y se regía por el interés y el principio de reciprocidad, mientras que la hospitalidad cristiana, entendida en sentido amplio, beneficiaba a los más pobres y no estaba regida por la selectividad y por la reciprocidad. Véase Crislip, A. T., op. cit., pp. 47-50.

76 Para el tema, véase González Cruz, M., Teología de la misericordia..., cit., pp. 224-239; id., "Ser bastantes. Variaciones de un tema de la Antigüedad clásica, presentes en la Información en derecho de Vasco de Quiroga", Efemérides Mexicana, vol. 24, 2006, pp. 3-36.

77 Quiroga, Vasco de, Información..., cit., III, 198. Este tema, que Quiroga toma de san Antonino de Florencia (C. Herrejón), tuvo presencia destacada en teólogos como Pérez de Varela. En Quiroga, la senectud de la Iglesia era transitoria, pues era la fase previa y necesaria a su reformación. 
Este libro forma parte del acervo de la Biblioteca Jurídica Virtual del Instituto de Investigaciones Jurídicas de la UNAM

motivo eclesiológico aparece ya en su Carta de 1531. Por lo que toca a lo segundo, éste refleja un remanente de la comprensión antigua y medieval de los hospitales, misma que - como queda dicho - fue ampliamente rebasada por nuestro personaje. A comienzos de 1536 y con ocasión de su juicio de residencia, él explicó las motivaciones que lo impulsaron a fundar sus hospitales:

...nada de ello es para mí sino para el dicho hospital... y para escuela y ejemplo de doctrina, caridad y piedad cristiana y de algunos estudiantes de gramática colegiales que allí la deprenden, y para un ejercicio muy llano y bueno de todas las obras de misericordia, así espirituales como corporales, y para allí curar enfermos y enterrar los muertos de la comarca y acoger los peregrinos y doctrinar los ignorantes y casar huérfanos y recoger vagamundos muchos que hay sin orden ni estado alguno de vivir y decirles y celebrarles misas y administrarles el santo y venerable bautismo con las ceremonias de él y todos los otros sacramentos... y para cementerio de todos los muertos de aquella comarca, que antes eran comidos de aves y perros y otros animales, y abrigo y amparo de muchos forzados y maltratados que pasan por el camino... ${ }^{78}$

Hay, sin embargo, otras diferencias notables entre ambos proyectos sociocristianos. Basilio — según los datos que nos ofrece su carta a Elías - pensó y realizó un proyecto meramente urbano, mientras que el proyecto de Quiroga era urbano y rural. En el proyecto de Basilio fueron los oficios y los talleres los medios para lograr una "vida digna"; en cambio, en el de Quiroga, los instrumentos para configurar al hombre autárkes y cristiano fueron los oficios "mecánicos" (cantería, herrería, telares, carpintería) ${ }^{79}$ y la agricultura, la cual debía ser practicada por todos ${ }^{80}$ tanto en el hospital como en las estancias y granjerías, que eran como una extensión del mismo. Esta combinación campo-ciudad (pólis en sentido aristotélico) respondía - como es obvio - a presupuestos

\footnotetext{
78 Texto en Warren, J. B., “Apéndice II”, op. cit., p. 183.

79 Quiroga, Vasco de, Ordenanzas..., cit., p. 100.

$80 \quad$ Ibidem, p. 92.
} 
Este libro forma parte del acervo de la Biblioteca Jurídica Virtual del Instituto de Investigaciones Jurídicas de la UNAM

de índole económica, pero no en menor escala al background pedagógico-humanista de Quiroga. Es bien conocida, en efecto, la propensión de los humanistas a un estilo de vida bucólico, como el descrito con maestría por uno de sus autores clásicos preferidos: Virgilio.

La segunda diferencia radica en el espíritu "comunista" de las que Natalie Zemon Davis considera communautés expérimentales, las cuales se sustentaban en la exclusión de la propiedad privada - aunque no total, como en el caso de Moro-, en la distribución de los bienes conforme a la necesidad ${ }^{81}$ y en un estilo de vida fuertemente político-comunitario, inspirado en la antropología filosófica de Aristóteles, en la Utopía de Moro y en el "primitivismo cristiano" idealizado por los reformadores de todos los tiempos, Quiroga entre ellos. ${ }^{82}$

Una tercera diferencia entre ambos personajes radicaría en la proyección integral y evangelizadora de la obra "hospitalaria" de Quiroga. Éste, en efecto, la pensó para poner "remedio" a la dispersión en que vivían los naturales; como espacio de protección y seguridad de sus personas (conservación); como instrumento para que ellos lograran una vida "política"; como herramienta para que los naturales superaran la ociosidad, y como espacio favorable a la conversión, al adoctrinamiento, al culto debido a Dios y a la consolidación de la moralidad cristiana.

...cosa razonable, probable y necesaria sería que se pensase y se entendiese en les ordenar de nuevo otra arte y manera y estado de vivir y de república en que viviesen en buena conversación y policía, en que se hiciesen bastantes y suficientes para sustentarse, así que no pereciesen y se acabasen de pura miseria... y juntamente con esto, juntarlos en ciudades para hacerles bastantes, tutos y seguros contra todas necesidades, injurias e incomodidades en los solos caen; porque como muchas veces está dicho, para esto se

$81 \quad$ Ibidem, pp. 87 y 88 .

82 El "motivo" del primitivismo cristiano aparece tempranamente en su "Carta al Consejo de Indias" (op. cit., p. 79). 
Este libro forma parte del acervo de la Biblioteca Jurídica Virtual del Instituto de Investigaciones Jurídicas de la UNAM

juntaron los hombres y se hicieron la ciudades con buenas leyes y ordenanzas y policías, para que con la comunicación deferente de los miembros de la sociedad, las cosas humanas marcharan no sólo con suficiencia, sino también de manera altamente apacibles. ¿Qué hemos, pues, de decir, sino ay del solo, etc. ${ }^{83}$

\section{CONCLUSIÓN}

450 años nos separan de la muerte del gran Tata, "Tata Vasco". La obra "hospitalaria" que nos legó testimonia que la compasión y la misericordia para con los desposeídos ni es dañina ni es una debilidad o enfermedad del espíritu, como enseñaban los estoicos antiguos y, mucho tiempo después, pensadores como F. Nietzsche. Sus hospitales-pueblo son muestra de que la compasión y la misericordia cristiana pueden ser creativas y contribuir a la dignificación de los excluidos y más empobrecidos de ayer, de hoy y de siempre.

Las realizaciones políticas de Basilio y de Quiroga no pueden pensarse como simples prolongaciones de la euergesía greco-romana, ni ellos reprodujeron la figura clásica del euergetes, pues no se interesaron en crear y desarrollar lazos clientelares con los pobres o ptochoi/macehuales, lazos que perpetuaran y profundizaran su estado de dependencia. El ideal del hombre autárkes, que, no sin ciertas inconsistencias, el funcionario real don Vasco de Quiroga quiso cuajar en sus hospitales-pueblo, se sitúa en las antípodas del modelo clientelar de ayer y hoy. Ésta es, sin duda, una de las razones sólidas que explican su presencia en la memoria de muchos de los habitantes de esta región del país.

No obstante, tanto el ambicioso proyecto de los hospitalespueblo como su realizador permanecen en la Edad Media, pues

83 Quiroga, Vasco de, Información..., cit., III, 246 (cursivas en el texto). También véase Quiroga, Vasco de, Información..., cit., II, 35, en donde se añade lo siguiente: "Así, pues, el que huye de la sociedad o es un loco rabioso o un ermitaño; mas el ermitaño en realidad no huye, pues se asocia a los dioses. Esto dice Cirilo". 
Este libro forma parte del acervo de la Biblioteca Jurídica Virtual del Instituto de Investigaciones Jurídicas de la UNAM

como lo advertía ya hace tiempo Natalie Zemon Davis, los proyectos sociales de ese largo espacio de tiempo no se pergeñaron para cambiar el orden social, sino para controlarlo y hacerlo funcionar lo mejor posible: "De plus, escribió la investigadora, au Moyen Age comme au XVI siècle, les pouvoirs ecclésistiques et laïques n'avaint pas la intention de se servir de la bienfaisance pour changer l'ordre social". ${ }^{84}$ La autora, al igual que muchos otros estudiosos dentro y fuera de este país, no deja de reconocer la singularidad de la obra hospitalaria quiroguiana, reconocimiento justo que compartimos a cabalidad.

\section{BIBLIOGRAFÍA}

"Bula de erección del obispado de Michoacán y carta jurídicopastoral de don Vasco", en COMISIÓn DE HistORIA DEL 450 ANIVERSARIO (ed.), Vasco de Quiroga y obispado de Michoacán, Morelia, Fimax Publicistas, 1986.

BASILIO DE C., "A Elie, gouverneur de la province", en SAINT BASILE, Lettres, trad. de Y. Courtonne, París, Les Belles Lettres, 1957.

Benavente, Toribio de, Historia de los indios de la Nueva España (estudio crítico, apéndices, notas e índices de E. O’Gorman), México, Porrúa, 1973.

, Memoriales (edición crítica, notas e introducción de N. J. Dyer), México, Colmex, 1996.

Bernand, C. y Gruzinski, S., Historia del Nuevo Mundo. Del descubrimiento a la conquista. La experiencia europea, 1492-1550, México, Fondo de Cultura Económica, 1996.

Bonis, K. G., "Basilios von Caesarea und die Organisation der christlichen Kirche in vierten Jahrhundert", en FEDWICK, P. J.

84 Zemon Davis, Natalie, "Assistance, humanisme et hérésie. Le cas de Lyon", en Mollat, M. (dir.), Études sur l'histoire de la pauvreté (Moyen âge-XVIe siècle), París, Publications de la Sorbonne, 1974, t. II, p. 785. 
Este libro forma parte del acervo de la Biblioteca Jurídica Virtual del Instituto de Investigaciones Jurídicas de la UNAM

(ed.), Basil of Caesarea: Christian, Humanist, Ascetic. A Sixteen-Hundredth Anniversary Symposium, Roma, PIMS, 1981.

Castañeda, Paulino, Don Vasco de Quiroga y su "Información en derecho", Madrid, Porrúa-Turanzas, 1974.

CRisliP, A. T., From Monastery to Hospital. Christian Monasticism \& the Transformation of Health Care in Late Antiquity, Ann Arbor, UMP, 2005.

DANIÉlou, Jean, "Pour une théologie de l'hospitalité", La Vie Spirituelle 84, 1951.

Fensham, F. C., "Widow, Orphan, and the Poor in Ancient Near Eastern. Legal and Wisdom Literature", fournal of Near Eastern Studies, vol. 21, 1962.

GAIN, B., L'Église de Capadoce au IV siècle d'après la correspondance de Basile de Césarée (330-379), Roma, PIO, 1985.

Galimard Flavigny, Bertrand, Les Chevaliers de Malte. Des hommes de fer et de foi, París, Gallimard, 2007.

GeremeK, B., La piedady la horca. Historia de la miseria y de la caridad en Europa, Madrid, Alianza, 1989.

GIET, S., Les idées et l'action sociales de Saint Basile, París, Gabalda, 1941.

GONZÁLEZ CRUZ, M., "Ser bastantes. Variaciones de un tema de la Antigüedad clásica, presentes en la Información en derecho de Vasco de Quiroga", Efemérides Mexicana, vol. 24, 2006.

- Teología de la misericordia, implícita en los escritos y en la praxis de Vasco de Quiroga, México, UPM, 2012.

González Faus, J. I., Vicarios de Cristo.

Gutiérrez, Gustavo, Dios o el oro de las Indias, Salamanca, Sígueme, 1990.

—_ En busca de los pobres de Fesucristo. El pensamiento de Bartolomé de las Casas, Salamanca, Sígueme, 1993.

Hiltbrunner, O., "Gastfreundschaft", RAC, VIII, 1972.

IMBERT, Jean (dir.), Histoire des hôpitaux en France, Toulouse, Privat, 1982. 
Este libro forma parte del acervo de la Biblioteca Jurídica Virtual del Instituto de Investigaciones Jurídicas de la UNAM

JeTTER, D., Das europäische Hospital von der Spätantike bis 1800, Köln, DuMont, 1986.

Karayannopoulos, I., "St. Basil's Social Activity: Principles and Praxis", en FeDwICK, P. J. (ed.), Basil of Caesarea: Christian, Humanist, Ascetic. A Sixteen-Hundredth Anniversary Symposium, Roma, PIMS, 1981.

Lindgren, U., "Hospital", Lexikon des Mittelalters, Múnich, DTV, 2003, vol. V.

Mara, M. G., "Laura", en Bernardino, A. di (dir.), Diccionario patrístico de la antigüedad cristiana II, Salamanca, Sígueme, 1998.

Milhou, Alain, "El concepto de «destrucción» en el evangelismo milenario franciscano", Actas del II Congreso Internacional sobre los franciscanos en el Nuevo Mundo (siglo XVI). La Rábida, 21-26 septiembre 1987, Madrid, Deimos, 1988.

Mollat, M. (dir.), Études sur l'histoire de la pauvreté (Moyen âge-XVIe siècle), París, Publications de la Sorbonne, 1974.

-, "Floraison de fondations hospitalières, XIIe et XIIIe siècles", en IMBERT, Jean (dir.), Histoire des hôpitaux en France, Toulouse, Privat, 1982.

, "La vie quotidienne dans les hôpitaux médievaux", en IMBERT, Jean (dir.), Histoire des hôpitaux en France, Toulouse, Privat, 1982.

, "Les premiers hôpitaux. VI-XI siècle", en IMBERT, Jean (dir.), Histoire des hôpitaux en France, Toulouse, Privat, 1982.

—, Die Armen im Mittelalter, Múnich, 1984.

-, Les pauvres au Moyen Âge. Étude sociale, París, Hachette, 1978.

Moreno, J. J., Fragmentos de la vida y virtudes de don Vasco de Quiroga (edición facsimilar y estudio introductorio de R. Alanís), Morelia, UMSH, 1998.

Nacianceno, Gregorio, Eis tòn mégan Basíleion epitáphios (Pour le grand Basile. Oraison funèbre) (introduction, texte critique, traduction et notes par J. Bernardi), París, Cerf, 1992. 
Este libro forma parte del acervo de la Biblioteca Jurídica Virtual del Instituto de Investigaciones Jurídicas de la UNAM

Paredes, G., "El tributo indígena en la región del lago de Pátzcuaro", en VARIOS AUTORES, Michoacán en el siglo XVI, Morelia, Fimax Publicistas, 1984.

Quiroga, Vasco de, "Carta al Consejo de Indias", en Aguayo SPENCER, R., Don Vasco de Quiroga, taumaturgo de la organización social. Seguido de un apéndice documental, México, Oasis, 1970.

, Información en derecho (introducción y notas de Carlos Herrejón Peredo), México, SEP, 1985.

, Ordenanzas de Santa Fe (introducción, paleografía y notas de J. B. Warren), Morelia, Fimax Publicistas, 1999.

, Testamento (edición facsimilar con otros documentos. Introducción, paleografía y notas por J. B. Warren), Morelia, Fimax Publicistas, 1997.

RICARD, R., La conquista espiritual de México. Ensayo sobre el apostolado $y$ los métodos misioneros de las órdenes mendicantes en la Nueva España de 1523-1524 a 1572, México, Fondo de Cultura Económica, 1994.

SAHAgún, B. de, Historia general de las Indias (edición crítica y apéndices de A. Ma. Garibay K.), México, Porrúa, 1989.

SAINT BASILE, "Lettre a Eusèbe, évêque de Samosata (Lettre XXVII) et Lettre a Eusébonas, évêque (L. XXXI)", en SAINT BASILE, Lettres, trad. de Y. Courtonne, París, Les Belles Lettres, 1957, t. I.

Todorov, T., La conquista de América. El problema del otro, México, Siglo XXI, 1995.

Verger, J., La renaissance du XIIe siècle, París, Cerf, 1999.

Waldstein-WartenBerg, Berthold, Die Vasallen Christi. Kulturgeschichte des Fohanniterordens im Mittelalter, Viena, Böhlau, 1988.

WARREN, F. B., "Vasco de Quiroga, fundador de hospitales y colegios", Missionalia Hispanica, núm. 67, 1966.

Warren, J. B., Vasco de Quiroga y sus hospitales-pueblo de Santa Fe, Morelia, UMSH, 1977.

Windemuth, M. L., Das Hospital als Träger der Armen Fürsorge im Mittelalter, Stuttgart, Steiner, 1995. 
Este libro forma parte del acervo de la Biblioteca Jurídica Virtual del Instituto de Investigaciones Jurídicas de la UNAM

ZaVala, S., De encomiendas y propiedad territorial en algunas regiones de la América española, México, Robredo, 1940.

Zemon Davis, Natalie, "Assistance, humanisme et hérésie. Le cas de Lyon", en MOLLAT, M. (dir.), Études sur l'histoire de la pauvreté (Moyen âge-XVIe siècle), París, Publications de la Sorbonne, 1974 , t. II. 
Este libro forma parte del acervo de la Biblioteca Jurídica Virtual del Instituto de Investigaciones Jurídicas de la UNAM

\title{
VASCO DE QUIROGA Y LOS INICIOS DEL IUS COMMUNE EN LA PROVINCIA DE VALLADOLID DE MICHOACÁN
}

\author{
Jaime HERnÁndez DÍAZ
}

\begin{abstract}
SUMARIO: I. Introducción. II. Formación intelectual. III. El pensamiento jurídico de Vasco de Quiroga en su acción en la Nueva España. IV. Bibliografia.
\end{abstract}

\section{INTRODUCGIÓN}

Agradezco la invitación para participar en este coloquio dedicado a la figura de Vasco de Quiroga con motivo del 450 aniversario de su muerte (1565-2015). Asisto en estricto sentido con la representación de la División de Estudios de Posgrado de la Facultad de Derecho y Ciencias Sociales, institución que propuso mi participación, y, desde luego, de la universidad heredera del Colegio de San Nicolás fundado por don Vasco de Quiroga: la Universidad Michoacana de San Nicolás de Hidalgo, de la que fui rector no hace muchos años. De San Nicolás se han ocupado destacados investigadores "nicolaitas", como Raúl Arreola Cortés y Ricardo León Alanís. Al ser propuesto por la Facultad de Derecho, en la que soy profesor de Historia del derecho, se pensó por los integrantes del cuerpo académico del que formo parte se abordara el pensamiento jurídico de don Vasco de Quiroga y su contribución a la formación de la cultura jurídica en la provincia de Michoacán.

La propuesta me pareció pertinente, pues cabe recordar que la Escuela de Jurisprudencia fundada en los inicios del siglo XX, antecedente inmediata de la actual facultad, siempre se sintió he- 
Este libro forma parte del acervo de la Biblioteca Jurídica Virtual del Instituto de Investigaciones Jurídicas de la UNAM

redera del pensamiento y obra de Vasco de Quiroga; así lo sostuvo el licenciado Miguel Meza en su discurso inaugural:

Por natural asociación de ideas, vienen a mi memoria y mis labios pronuncian con respeto dos nombres venerados: Don Vasco de Quiroga y Don Melchor Ocampo, fundador aquel varón ilustre y restaurador este insigne republicano, del Colegio Primitivo de San Nicolás, plantel de tradiciones gloriosas y el más antiguo de América; de una vida tres veces secular. De allí se derivan, como las ramas que se desgajan del árbol corpulento, la Escuela de Medicina y la Escuela de Jurisprudencia, y debido al espíritu de progreso de un gobernante patriota, ha nacido a la vida independiente sin conmociones ni hostilidades, sino como una lógica evolución en el desenvolvimiento de las sociedades. ${ }^{1}$

En los cursos de Historia del derecho, aspiro a que esto no quede en mera retórica y propicio el estudio de Vasco de Quiroga en el proceso formativo de la cultura jurídica novohispana. El trabajo que presento forma parte de mi curso; en consecuencia, no tiene mayores pretensiones.

Esta breve y humilde reflexión no está basada en nuevos materiales documentales o archivísticos; en esta materia no esperen encontrar nada novedoso, pues utilizo los textos conocidos que estuvieron a mi alcance. No obstante, este documento intenta, eso sí, reflexionar sobre una faceta conocida de la personalidad de Vasco de Quiroga, pero - desde mi punto de vista - insuficientemente abordada, es decir, el pensamiento jurídico de Quiroga. En particular, se hace necesario explorar las ideas del ius commune y del pluralismo jurídico contenido en los textos que conocemos de él, y situar en ese campo del pensamiento las acciones de Quiroga en la Nueva España y, por supuesto, en Michoacán.

Esta reflexión se enmarca en el estudio de la cultura jurídica; el destacado jurista italiano Luigi Ferrajoli la concibe como un

1 Boletín de la Escuela de Furisprudencia, Morelia, núm. 1, 15 de abril de 1901 , p. 2. 
Este libro forma parte del acervo de la Biblioteca Jurídica Virtual del Instituto de Investigaciones Jurídicas de la UNAM

conjunto o suma de diferentes conjuntos de saberes y enfoques, en los que localiza tres aspectos distintos:

...en primer lugar, el conjunto de teorías filosóficas y doctrinas jurídicas elaboradas por juristas y filósofos del derecho en una determinada fase histórica; en segundo lugar, el conjunto de ideologías, modelos de justicia y modos de pensar sobre el derecho propios de los operadores jurídicos profesionales, ya se trate de legisladores, de jueces o administradores; en tercer lugar, el sentido común relativo al derecho y a cada institución jurídica difundido y operativo en una determinada sociedad. ${ }^{2}$

La organización jurídica y política que se estableció en la provincia de Valladolid de Michoacán, bajo el influjo de la cultura jurídica que acompañó al proceso de conquista y colonización, se realizó con base en una recepción de la cultura jurídica europea, de alguna manera con las características que se fueron adoptando en el viejo continente y, principalmente, en España. Javier Barrientos Brandon afirma que inicialmente se recibió la cultura del ius commune junto a la escuela española del derecho natural, el humanismo jurídico y el iusracionalismo. ${ }^{3}$ Este autor ha identificado tres grandes vías por las que la cultura del ius commune se transmitió en la Nueva España: la vía oficial o real, la académica y la práctica judicial. El derecho común romano canónico — sostiene este autor chileno- se transmitió por vía oficial, especialmente por medio de las Siete Partidas, que tuvieron una amplia aplicación en materia de derecho privado y ante la escasa presencia de un derecho municipal y de manera inicial la inexistencia del derecho foral. Desde el punto de vista académico, esta cultura jurídica se divulgó por medio de las universidades, que se establecieron siguiendo el modelo que tenían en el viejo mundo: a través de la enseñanza del derecho y por

2 Ferrajoli, Luigi, Ensayos sobre la cultura jurídica italiana del siglo XIX, México, UNAM, Instituto de Investigaciones Jurídicas, 2010, p. 1.

3 Barrientos Grandon, Javier, La cultura jurídica en la Nueva España, México, UNAM, 1993, p. 11. 
Este libro forma parte del acervo de la Biblioteca Jurídica Virtual del Instituto de Investigaciones Jurídicas de la UNAM

medio de la literatura jurídica. No menos importante resultó la transmisión en la práctica judicial, pues se estableció una justicia en manos de letrados, de tal forma que se aprecia en estrados, en la actividad de los oidores y en las sentencias pronunciadas, así como en los dictámenes de asesores letrados que deberían seguir los jueces legos, es decir, a través de una judicatura letrada. ${ }^{4}$

Parece que debería incorporarse en estas vías de transmisión de la cultura jurídica a la Iglesia y, en particular, el tema que nos ocupa, con motivo del establecimiento del obispado de Michoacán. El obispado, constituido por una red de parroquias, juzgados eclesiásticos y doctrinas, jugó un papel fundamental en la divulgación de la cultura jurídica bajo una influencia del ius commune, sobre todo en su vertiente canónica; así, los asuntos administrativos, religiosos, contenciosos, civiles y de competencias asignadas a la Iglesia requerían de conocimientos precisos del derecho. En torno de esta organización de la Iglesia en el obispado, la divulgación del ius commune en su vertiente canónica es trascendental en la región, lo que nos lleva a no olvidar esta vertiente en la cultura jurídica novohispana. Recordemos que desde sus primeros años de vida, la Iglesia, a la vez que sus esfuerzos se dirigían a fijar la ortodoxia religiosa, de manera lenta pero sistemática, fue formando el derecho canónico. El obispado de Michoacán integró una red de parroquias, juzgados eclesiásticos y doctrinas, junto a cofradías, hospitales y escuelas. Dentro de este proceso jugaron un papel destacado los clérigos y religiosos que se habían formado en las instituciones educativas ubicadas en su espacio territorial, desempeñaban sus funciones en el mismo, y fueron generando una conciencia de identidad y de pertenencia al obispado, de ahí la trascendencia de los colegios y estudios conventuales. ${ }^{5}$

\section{Ibidem, pp. 11 y 12.}

5 Herrejón Peredo, Carlos, "Colegios e intelectuales en el obispado de Michoacán. 1770-1821”, en Serrano Ortega, José Antonio (coord.), La guerra de independencia en el obispado de Michoacán, Zamora, El Colegio de MichoacánSecretaría de Cultura del Gobierno de Michoacán, 2010, pp. 54 y 55. 
Este libro forma parte del acervo de la Biblioteca Jurídica Virtual del Instituto de Investigaciones Jurídicas de la UNAM

\section{FORMACIÓN INTELEGTUAL}

La figura de don Vasco de Quiroga, así como su obra realizada en la Nueva España, desde hace tiempo llama la atención de historiadores, filósofos y juristas; por ello, no es de extrañar una abundante bibliografia del personaje: desde los trabajos pioneros de Juan José Moreno y Nicolás León, pasando por los trabajos de Silvio Zavala, Justino Fernández, Edmundo O’Gorman, y más recientemente los excelentes estudios de J. B. Warren, Carlos Herrejón y Alberto Carrillo. En realidad, la vasta bibliografía sobre el personaje se enriquece constantemente con nuevos e interesantes trabajos. Ya desde 1954 Alfonso Trueba reconocía la existencia de muchos y buenos libros sobre Vasco de Quiroga, por lo que consideraba que "agregar uno más a los publicados sin ofrecer novedad, sería trabajo inútil"; ${ }^{6}$ no obstante, se atrevió a publicar un pequeño ensayo biográfico "bajo el supuesto de que no sólo útil, sino necesario, es divulgar la historia de personaje tan eminente, en el panorama de nuestra cultura". 7 Aceptando como válida esta afirmación, nos atrevemos a reflexionar sobre el destacado primer obispo de Michoacán, haciendo nuestra la recomendación de uno de sus más recientes estudiosos, Alberto Carrillo, quien considera que "recuperar una imagen más auténtica de la persona y la obra de este gran fundador del nuevo Michoacán y de la iglesia indiana en esta provincia puede ser un avance en la tarea de la consolidación de la memoria colectiva nacional y la reconstrucción de nuestra historia espiritual". ${ }^{8}$

Para explicar mejor las ideas del pluralismo jurídico en Quiroga se hace necesario ubicar a nuestro personaje en el tiempo en que se formó intelectualmente y las características de las instituciones jurídicas que conoció y aplicó a lo largo de su vida.

6 Trueba, Alfonso, Don Vasco, México, Jus, 1958, p. 3.

7 Idem.

8 Carrillo Cazares, Alberto, Vasco de Quiroga: la pasión por el derecho, Zamora, El Colegio de Michoacán-Arquidiócesis de Morelia-Universidad Michoacana de San Nicolás de Hidalgo, 2003, p. 14. 
Este libro forma parte del acervo de la Biblioteca Jurídica Virtual del Instituto de Investigaciones Jurídicas de la UNAM

Es ampliamente conocido que fue originario de la Villa de Madrigal de las Altas Torres; uno de sus mejores estudiosos, B. Warren, sitúa su nacimiento entre 1477 o $1478,{ }^{9}$ esto es, en las postrimerías de la Baja Edad Media española. Sabemos por él mismo Quiroga que estudió la licenciatura en derecho canónico; sin embargo, se desconoce si la hizo en Valladolid o en Salamanca. Francisco Miranda, al igual que otros de sus biógrafos, se orienta por señalar como más probable que Quiroga realizara sus estudios en la Universidad de Salamanca, pues en ella se desempeñaba como rector don Juan de Tavera, personaje muy cercano a la familia Quiroga. Su estadía en Salamanca debió ocurrir entre 1505-1515.10 Más allá de la duda sobre el lugar de sus estudios es necesario subrayar su formación no sólo por ser jurista, sino porque se desenvolvió en una sociedad con una clara influencia del derecho. En realidad, es poco significativo para los fines del estudio de la formación jurídica de Vasco de Quiroga dilucidar el lugar en que estudio, ya que todas las universidades de la época formulaban sus planes de estudio en torno a la cultura del ius commune.

Hoy se acepta a la época medieval como una sociedad con una gran cultura jurídica. En efecto, historiadores de la trascendencia de Jacques Le Goff reconocen el prestigio del derecho como una de las características de este periodo de la historia; ${ }^{11}$ no sólo eso, otros autores asocian el nacimiento de los sistemas jurídicos occidentales hacia fines del siglo XI y durante el siglo XII con el establecimiento de las primeras universidades europeas, principalmente con la Escuela de Derecho de Bolonia. ${ }^{12}$ El sistema de enseñanza de Bolonia, basado en el estudio del derecho romano

9 Warren, J. B., Vasco de Quiroga y sus hospitales-pueblo de Santa Fe, Morelia, Universidad Michoacana de San Nicolás de Hidalgo, 1977, pp. 9-14.

10 Miranda Godínez, Francisco, Don Vasco de Quiroga y su Colegio de San Nicolás, Morelia, Universidad Michoacana de San Nicolás de Hidalgo, 1990, pp. 16-18.

11 Le Goff, Jacques, En busca de la Edad Media, Barcelona, Paidós, 2003, pp. 114-117.

12 Berman, Harold J., La formación de la tradición jurídica de Occidente, México, Fondo de Cultura Económica, 1996, pp. 130-142. 
Este libro forma parte del acervo de la Biblioteca Jurídica Virtual del Instituto de Investigaciones Jurídicas de la UNAM

elaborado en la época de Justiniano - cuyo descubrimiento cerca de 1080 se realizó con la localización de una copia de la compilación hecha por el emperador bizantino-, fue trasplantado a muchas otras ciudades de Europa, incluyendo Padua, Perusa, Pisa, Salamanca, Montpellier, Orleáns, Praga, Viena, Cracovia y Heidelberg. Posteriormente, el programa de derecho en Bolonia, París, Oxford y otras universidades de Europa se extendió para incluir algo más que el derecho romano contenido en el Corpus Iuris Civilis. La principal materia nueva, añadida en la segunda mitad del siglo XII, fue el recién desarrollado derecho canónico de la Iglesia, que a diferencia del derecho romano representaba un derecho de actualidad. ${ }^{13}$

Los estudios de derecho de las universidades españolas, al igual que las europeas, se centraban en el ius commune romano-canónico, esto es, tenían como pilares de estudio al Corpus Iuris Civilis y al Corpus Iuris Canonici, explicados en las cátedras de leyes, Código, Instituta, Digesto Viejo y Volumen y en la de Prima, y Vísperas de Cánones, Decreto, Decretales, Sexto y Clementinas. ${ }^{14}$

Una de las características de la enseñanza del derecho que se impartía en las universidades de la época consistía en que los juristas en un momento determinado podían optar por el estudio del derecho canónico o por el civil, ambos realizados bajo las técnicas de los glosadores, dominando hacia fines del medioevo tanto el mos italicus como el mos gallicus, y, a su vez, su práctica jurídica tenía una estrecha relación con la actividad desempeñada por los teólogos. En este sentido, Antonio García y García afirma lo siguiente:

Teólogos y canonistas tenían en común un factor que aunaba sus esfuerzos ya que unos y otros utilizaron todo su bagaje de fuentes y de conocimientos teológicos y jurídicos, así como su reflexión jurídico-teológica, para dar respuesta a los grandes problemas de su tiempo. Esto les obligaba a ser interdisciplinarios y ambidex-

13 Idem.

14 Barrientos Grandon, Javier, op. cit., p. 38. 
Este libro forma parte del acervo de la Biblioteca Jurídica Virtual del Instituto de Investigaciones Jurídicas de la UNAM

tros para manejar a la vez conocimientos filosófico-teológicos y jurídicos tanto canonistas como civilistas... ${ }^{15}$

Por otra parte, hoy se acepta que la sociedad medieval, que aún le tocó conocer a Vasco de Quiroga, se caracterizaba por la coexistencia de diferentes órdenes jurídicos en el seno de un ordenamiento jurídico más amplio que se conoce con la denominación de "pluralismo jurídico". Paolo Grossi ha recomendado acercarse al derecho medieval, entendiéndolo

...como a una gran experiencia jurídica que alimenta en su seno una infinidad de ordenamientos, donde el Derecho — antes de ser norma y mandato - es orden de lo social, motor espontáneo, lo que nace de abajo, de una sociedad que se auto tutela ante la litigiosidad de la incandescencia cotidiana construyéndose esta autonomía, horcacina propia y auténtica protectora del individuo y de los grupos. La sociedad se impregna de Derecho y sobrevive porque ella misma es, antes que nada, Derecho, debido a su articulación en ordenamientos jurídicos. ${ }^{16}$

Por consiguiente, el derecho medieval constituyó una experiencia jurídica en la que convivían diversos ordenamientos jurídicos creando espacios de autonomía muy diferente a la idea de soberanía moderna, con una manifestación jurídica muy fuerte que representaba "la auténtica constitución del universo medieval, una dimensión óntica precedente y dominante de aquella política". ${ }^{17}$

Durante este periodo se encuentra en vigor un derecho común que coexistía en equilibrio con los derechos propios; este derecho común disponía de una vigencia potencialmente general, esto es, se aplicaba a todas las situaciones no contempladas por los derechos propios o particulares, como bien señala António

15 García García, Antonio, "Derecho romano-canónico en la península ibérica", en Alvarado, Javier (ed.), Historia de la literatura jurídica en la España del antiguo régimen, Madrid, Marcial Pons, 2000, pp. 128 y 129.

16 Grossi, Paolo, El orden jurídico medieval, Madrid, Marcial Pons, 1996, p. 52.

17 Ibidem, p. 56. 
Este libro forma parte del acervo de la Biblioteca Jurídica Virtual del Instituto de Investigaciones Jurídicas de la UNAM

Manuel Hespanha: "En lugar de ser un sistema cerrado de niveles normativos, con relaciones definidas de una vez por todas (como en los sistemas de fuentes del derecho propios del legalismo contemporáneo), el derecho común constituía una constelación abierta y flexible de órdenes cuya arquitectura tan sólo podía determinarse en el caso concreto". ${ }^{18}$

\section{EL PENSAMIENTO JURÍDICO DE VASGO DE QUIROGA EN SU ACGIÓN EN LA NUEVA EsPAÑA}

Situar a Quiroga dentro de una corriente de pensamiento no es una tarea intrascendente. Derivado de su proyecto de los puebloshospitales de Santa Fe y la influencia del pensamiento de Tomás Moro, Quiroga suele ser reconocido como un renacentista; sin embargo, si se revisa la obra en su conjunto parece más acercarse al pensamiento jurídico teológico de claro corte medieval. Considero que quien acierta a ubicar mejor su pensamiento es Paz Serrano Gasset, misma que encuentra que

Además de la influencia de esta renovada teología, se encuentran en Quiroga numerosos restos del pensamiento medieval anterior en particular en las cuestiones referentes a los ámbitos y relaciones entre los poderes eclesiástico y temporal, lo que sitúa como un personaje de posiciones intermedias entre el medievalismo cristiano y la escolástica española de la época. Sus precedentes medievales se remontan a la teología sentencialista y la filosofía tomista. La primera, en una línea agustiniana, exaltaba el orden sobrenatural y la importancia de la gracia, por encima del orden temporal, por lo que terminaba concluyendo la primacía del poder de la Iglesia y de los derechos de la cristiandad sobre los pueblos infieles. La segunda trataba de armonizar ambos órdenes, resaltando la importancia de los derechos naturales, que por esencia, se encontraba en todos los hombres, fieles e infieles. Apli-

18 Hespanha, António Manuel, Cultura jurídica europea. Sintesis de un milenio, Madrid, Tecnos, 2002, p. 99. 
Este libro forma parte del acervo de la Biblioteca Jurídica Virtual del Instituto de Investigaciones Jurídicas de la UNAM

cadas a problemas diferentes, las dos concepciones aparecen en los textos [de Quiroga]. ${ }^{19}$

En la polémica jurídica suscitada en torno a la conquista de las tierras americanas, Manuel Ma. Salord Bertrán ubica tres etapas: la primera abarca desde los primeros descubrimientos y lo que él llama "el colonialismo de la primera conquista"; la segunda comprende los años de 1512 a 1533 y se caracteriza por el uso del "requerimiento", y la tercera se sitúa del año 1533 a 1546 y se encuentra permeada por la elaboración de las llamadas "Leyes Nuevas". En la segunda etapa se desarrolla la polémica derivada básicamente de la discusión sobre la validez o no de los Justos Títulos esgrimidos a favor de la teocracia papal, tesis que tiene profundas raíces medievales - argumentación contradicha por los críticos de la misma en el marco del nacimiento de la soberanía estatal-.

Así como prácticamente se desconoce el lugar de sus estudios, se conoce muy poco de los primeros años de la vida, digamos, profesional de Vasco de Quiroga. A pesar de todo, queda claro que se desempeñó como funcionario real en las instancias de la Corte de Carlos V, y particularmente se le ubica con mayor claridad en 1526 como juez de residencia en Orán, África, antes de pasar como miembro de la Segunda Audiencia de México a la Nueva España.

Estando cerca de las instancias reales, no le fue ajena la polémica jurídica que se entabló con respecto a la conquista del Nuevo Mundo y la justificación esgrimida por la Corona en torno a los Justos Títulos. Probablemente, Vasco de Quiroga conoció las discusiones de la Junta de Burgos (1512) y las leyes que surgieron de esa reunión con ese nombre, en las que se reconoció la libertad del indio y se creó el documento conocido como "Requerimiento", explicación formal que los conquistadores debían realizar a los indios, en donde se les comunicaba los títulos que

19 Serrano Gasset, Paz, Vasco de Quiroga. La utopía en América, Madrid, Dastin, 2003, p. 25. 
Este libro forma parte del acervo de la Biblioteca Jurídica Virtual del Instituto de Investigaciones Jurídicas de la UNAM

justificaban el derecho de conquista en nombre de la Corona. El Requerimiento fue elaborado por el jurista y consejero real Juan López de Palacios Rubio, en el que colaboró el teólogo y catedrático de la Universidad de Salamanca, fray Matías de Paz.

Vasco de Quiroga, seguramente, tuvo conocimiento de la Junta de Valladolid de 1513, en la que se reconoció por unanimidad la validez del título de donación de las tierras americanas otorgadas por el papa, y se acordó que el rey podía, a través de sus oficiales, requerir que le dieran la tierra o tomarla por la fuerza si los indios se oponían.

Vasco de Quiroga no es ajeno a ese proceso de revisión de la autoridad real. Así pues, en la Ordenanza de 1526 se establece que

... [los] indios sean tratados como seres libres y no como esclavos, y que sean gobernados con justicia, sin imponerles demasiados trabajos ni llevarlos a las minas contra su voluntad y siempre con el parecer del prelado o de su representante en el lugar, procurando atraer a los indios a la fe cristiana y señorío de España por el convencimiento y la prudencia política. Encargo a clérigos y religiosos y "todas las conciencias" la protección de los indios, obligándoles a avisarle de cualquier abuso o injusticia cometida por cualquier persona de cualquier calidad que sea "para que nos y los de nuestro Consejo lo mandamos ver y castigar con todo rigor". ${ }^{20}$

En los años en que no hay duda que Quiroga es un funcionario real, es decir, durante los primeros años del reinado de Carlos $\mathrm{V}$, las instituciones que habían articulado la primera conquista de América - esclavitud, encomiendas y guerras de conquista- se someten a una revisión profunda, hasta llegar a la promulgación de las Reales Ordenanzas, del 17 de noviembre de 1526, sobre la forma en que se deben hacer los descubrimientos y rescates en las Indias. ${ }^{21}$

20 Salord Bertrán, Manuel Ma., La influencia de Francisco de Vitoria en el derecho indiano, México, Porrúa, 2002, p. 123.

21 Ibidem, p. 62. 
Este libro forma parte del acervo de la Biblioteca Jurídica Virtual del Instituto de Investigaciones Jurídicas de la UNAM

Por otro lado, en las Cortes se tomaban las medidas que llevaron a las Ordenanzas de 1526; en el campo teórico, Francisco de Vitoria obtenía la cátedra de Prima de Teología en la Universidad de Salamanca (1526). A finales de 1528, en su Relección de potestate civili manifestaba su pensamiento sobre la soberanía temporal y de la razón que amparaba a los pueblos del continente para que en sus relaciones con los de Europa se aplicara el derecho de gentes; en 1532, en su Relección de potestate eclesiae llega a la conclusión siguiente: Papa non est orbis dominus. ${ }^{22}$

En su calidad de oidor en la Segunda Audiencia de México se enfrentó directamente a los problemas esenciales que abordan los funcionarios reales y los intelectuales de la época: la guerra y la esclavitud. Asimismo, Vasco de Quiroga participó en las juntas eclesiásticas de 1531 y 1532: en la primera de ellas el tema principal de la agenda era el tomar parecer sobre la guerra de conquista emprendida por Nuño de Guzmán, y en la segunda trataba de moderar el empleo de cargadores o tamemes y la suerte de los indios en el tema de la esclavitud. En esas reuniones se estaba gestando la Información en derecho.

Del periodo en que se desempeñó como oidor de la Audiencia de México es su escrito conocido, hoy en día, con el título de Información en derecho. Si bien es cierto que se ha considerado que este texto es un informe de Quiroga dirigido al Consejo de Indias - al parecer al consejero Bernal de Luco-, está elaborado como un alegato jurídico; por lo tanto, nos es útil para acercarnos al pensamiento jurídico de Quiroga, limitándonos por ahora fundamentalmente a sus comentarios en torno al papel que juegan en la sociedad los ordenamientos jurídicos de su época. En este texto se refleja ampliamente la cultura jurídica de Vasco de Quiroga típica del ius commune, como lo ha subrayado Carlos Herrejón. No es de extrañar, en consecuencia, que este texto se encuentre construido apoyándose en el cuerpo del derecho romano compilado por Justiniano, en el cuerpo del derecho canónico y en el uso de fuentes teológicas de la época; además, se inscribe

22 Ibidem, pp. 123 y 124. 
Este libro forma parte del acervo de la Biblioteca Jurídica Virtual del Instituto de Investigaciones Jurídicas de la UNAM

en los usos y características de la literatura jurídica castellana de la época. Estos juristas, generalmente, elaboraron sus obras en castellano, y la mayoría de los aparatos de glosa se encuentran en latín, a diferencia de las obras que se producían en Francia e Italia, las cuales se escribían en su conjunto en latín, ya que era el lenguaje culto de la época. ${ }^{23}$

De tal forma que en la década de los treinta, cuando Vasco de Quiroga escribe su Información en derecho, se escuchaban voces críticas a dicha teoría. Quiroga se sitúa en la pura ortodoxia de la teoría medieval para justificar la validez de las bulas papales, de ahí parte todo su proyecto y compromiso evangélico en la Nueva España; seguramente, nunca abandonó su convicción de la validez de tales títulos, pues consideraba una verdadera obligación cumplir con la disposición establecida en la bula papal:

...Porque, donde entre gentes mayormente bárbaras se han de enjerir e introducir de nuevo buenas costumbres y desarraigar las malas y plantarse la fe de nuestra cristiana religión con la esperanza y caridad della, y esto en tierra tan extraña y ajena de semejantes virtudes, y no por sola voluntad, sino por una muy fuerte y firme obligación de la bula del Papa Alexandro, concedida a los Reyes Católicos, de la gloriosa memoria, que me parece que trae más que aparejada ejecución, cierto gran miramiento y recatamiento y diligencia es menester. ${ }^{24}$

Este pensamiento de corte medieval, por supuesto, lo entiende no sólo desde el punto de vista de las tareas evangélicas derivadas de él, sino también de las facultades reconocidas a los Reyes Católicos y sus sucesores, tanto en lo espiritual como en lo temporal, para gobernar y evangelizar las tierras del Nuevo Mundo. Así lo reconoce Vasco de Quiroga en otra parte del texto de la Información en derecho:

23 Pérez Martín, Antonio, "La literatura jurídica castellana en la Baja Edad Media", en Alvarado, Javier (ed.), Historia de la literatura jurídica en la España del antiguo régimen, Madrid, Marcial Pons, 2000, p. 72.

24 Ibidem, p. 68. 
Este libro forma parte del acervo de la Biblioteca Jurídica Virtual del Instituto de Investigaciones Jurídicas de la UNAM

Y pues su Majestad, como rey y señor y apóstol deste Nuevo Mundo, a cuyo cargo está todo el grand negocio de él en temporal y espiritual, por Dios y por el Sumo Pontífice a él concedido, tiene todo el poder y señorío que es menester para regir y encaminar, gobernar y ordenar, no solamente se les puede, pero aun se les debe (como lo manda y encarga la bula), por su Majestad mandar, dar una tal orden y estado de vivir, en que los naturales para sí y para los que han de mantener sean bastantes y suficientes, y en que se conserven y conviertan bien como debe... ${ }^{25}$

Esta actitud es explicable por la formación jurídica de don Vasco o las lecturas que fortalecen su visión teórica de los problemas; además, en su obra utiliza exponentes de la tesis teocrática, como san Antonio de Florencia, quien vivió entre 1389-1459 y que fue un dominico arzobispo de Florencia muy reconocido por sus trabajos de teología, en los que abordó cuestiones relativas al derecho civil y de carácter eclesiástico. Su obra principal, intitulada Summa Theologica, defiende con amplitud las facultades del romano pontífice en ambas potestades. ${ }^{26}$ Igualmente, Quiroga cita en varias ocasiones a fray Tomás de Vio Cayetano, integrante también de la orden de los dominicos y que es un teólogo más ubicado en el contexto del Renacimiento, pues vivió de 1469 a 1534; se desempeñó como profesor en Padua y Pavía, y llegó a ser vicario general de su orden. Cayetano fue defensor vigoroso de las prerrogativas espirituales del papado y del poder del papa en asuntos temporales, mismas que, según él, le vienen en función de su quehacer espiritual, es decir, de manera indirecta. Asimismo, estas lecturas influyen en el tratamiento que hace del problema de los indígenas. Esta postura en torno a las bulas papales explica por qué diversos autores señalan que en esta materia Quiroga no aportó nada nuevo a la discusión y se sitúa en el espíritu ortodoxo de la teología.

\section{Ibidem, p. 118.}

26 Castañeda Delgado, Paulino, La teocracia pontifical en las controversias sobre el Nuevo Mundo, México, UNAM, Instituto de Investigaciones Jurídicas, 1996, pp. 197-199. 
Este libro forma parte del acervo de la Biblioteca Jurídica Virtual del Instituto de Investigaciones Jurídicas de la UNAM

No es el único asunto en el que Quiroga se sitúa con un enfoque tradicional, pues también lo hace en asuntos centrales que se discutían en el seno de las Cortes y entre los intelectuales españoles; por ejemplo, el problema de la guerra y la esclavitud, donde en ambos parte de la teoría tomista sobre la guerra justa, y en diversas ocasiones concluye en el carácter injusto de la misma, como la emprendida por Nuño de Guzmán en el occidente de México. La defensa de la población indígena y sus derechos las realiza en el marco de las disposiciones legislativas emitidas en 1526 y en los textos teológicos que maneja con la destreza del jurista-teólogo de la época; por ejemplo, san Antonio de Florencia había abordado el problema del poder del papa sobre los infieles, y llegó a la conclusión de que ni el papa ni los príncipes cristianos debían arrebatar a los gentiles sus bienes ni su gobierno, pues estos derechos forman parte de los "bienes naturales" que Dios ha dejado a todos, incluso a los demonios, es decir, utiliza conceptos iusnaturalistas que intenta asociar con la teoría teocrática. ${ }^{27}$ Particularmente, el cardenal de San Sixto, fray Tomás de Vio Cayetano, hizo una clasificación de los infieles, y en la tercera, sin mencionar específicamente a los indígenas americanos, parece referirse a ellos; éstos serían súbditos nec de iure nec de facto en cuanto a la jurisdicción temporal, paganos que nunca estuvieron sometidos al Imperio romano y habitan tierras que nunca fueron de los cristianos. ${ }^{28}$

Por otra parte, llama la atención la cita y el uso de la fuente que Quiroga hace en varias partes del escrito, de la compilación de leyes conformada en la época de Alarico y el papel que le asigna al derecho real o sus antecedentes. En torno a este tema, Silvio Zavala señala que uno de los hallazgos del estadounidense Roos Dealy es haber identificado la obra que emplea Quiroga para referirse al derecho visigodo; dicho autor ubica esta cuestión en el libro impreso en Lovaina en 1517, que lleva por título Summae sive

\section{Idem.}

28 Idem. 
Este libro forma parte del acervo de la Biblioteca Jurídica Virtual del Instituto de Investigaciones Jurídicas de la UNAM

argumenta legum diversorum imperatorum, ${ }^{29}$ bajo la autoría de un Pedro Giles. Más allá de la rareza de la obra, lo que destaca es que Quiroga apoye varios de sus argumentos en las leyes de la época de los visigodos anteriores a los inicios del derecho real castellano y muy poco utilizadas por los juristas de la época; además, lo hace otorgándole autoridad, sin desmerecer la que le concede a las leyes del Corpus Iuris. Esto lo expresa de la siguiente manera:

...como lo dice una ley en la suma de las leyes mandadas sacar por el rey Alarico, cristiano y godo y lo que pienso por ventura de las Españas que parece que las hace de ser más autoridad, demás de ser sacadas del cuerpo de las leyes del cristianísimo emperador Teodosio y de las novelas del emperador Valentiniano Augusto y de otros emperadores a quien tanto San Ambrosio alaba en sus epístolas, y de las sentencias y pareceres de los jurisconsultos Cayo Julio y Paulo, no de menor autoridad por ventura que las otras leyes del cuerpo del derecho común de los emperadores que tenemos de donde estas sumas o las más de ellas se sacan. Pues según leyes del reino tampoco se pueden alegar las otras incorporadas en el cuerpo del derecho civil sino solamente por razones naturales de sabios varones... ${ }^{30}$

Por la redacción del texto parece que Vasco de Quiroga se está refiriendo al Breviario de Alarico y no a otro libro; probablemente, ésta sea una edición reciente o un texto que utilizaba las referencias de la propia recopilación de Alarico. El Breviario de Alarico, mejor conocido como Lex Romana Visigothorum, fue promulgado por Alarico II en el año 506; este Breviario no contiene leyes de los reinos visigodos, sino que es una compilación del derecho romano posclásico en su doble vertiente: leges y iura. ${ }^{31}$ Las

29 Zavala, Silvio, Por la senda hispana de la libertad, México, Fondo de Cultura Económica-MAPFRE, 1993, pp. 220 y 221.

30 Quiroga, Vasco de, Información en derecho, biografia e ideario, Morelia, Universidad Michoacana de San Nicolás de Hidalgo-Gobierno del Estado de Michoacán, 1992, pp. 143 y 144.

31 Tomás y Valiente, Francisco, "Manual de historia del derecho español", Obras completas, Madrid, Centro de Estudios Políticos y Constitucionales, 1997, vol. II, p. 1016. 
Este libro forma parte del acervo de la Biblioteca Jurídica Virtual del Instituto de Investigaciones Jurídicas de la UNAM

disposiciones emanadas del emperador, que reciben el nombre de leges, constituyen la principal fuente del derecho, y las obras de la jurisprudencia clásica se conocen con el nombre de ius o iura. ${ }^{32}$ $\mathrm{Al}$ parecer, la obra de Alarico tuvo un sentido político para ganar a los francos, ofreciéndoles una buena compilación del derecho romano por el que tal población se regía, y por otra parte, tenía un sentido técnico: aclarar el derecho, suprimir de él textos inútiles y eliminar ambigüedades. ${ }^{33} \mathrm{El}$ Breviario fue elaborado por diversos juristas y promulgado en una asamblea de obispos y condes celebrada en Aduris, actual territorio francés; fue firmado como prueba de autenticidad por el varón Aniano, y Alarico ordenó que en adelante se utilizaría para resolver litigios y negocios en sus tribunales, y que no se aplicaría ninguna otra ley. ${ }^{34}$

A Vasco de Quiroga le atrajo también que las leyes de Alarico hayan sido el resultado de un trabajo de depuración de diversas disposiciones; como sabemos, se realizó por los juristas comisionados para ello por Alarico, lo cual constituye una actividad semejante a la que hicieron con posterioridad los juristas castellanos en la compilación de sus diversos cuerpos de leyes. De esa manera, Quiroga ponderaba las ventajas de leyes diseñadas con esas características: “...por ser sacadas y sumadas y corregidas y enmendadas, como grano más limpio y más puro y más claro, ahechado y apartado de la paja de lo superfluo, inicuo y ambiguo dellas, como parece por este autorizamiento y prefación que esta en el principio del libro...". 35

Este comentario de Quiroga coincide con otra parte de la Información en derecho, en la que critica las características del derecho castellano, que estaba disperso en diferentes leyes y era difícil de aplicarse a los grupos indígenas, por lo que recomienda la aplicación de leyes adecuadas a las costumbres de los indígenas y

32 Fernández de Buján, Antonio, Derecho público romano y recepción del derecho romano en Europa, Madrid, Civitas, 1999, pp. 150 y 151.

33 Quiroga, Vasco de, op. cit., p. 1016.

34 Idem.

35 Ibidem, p. 144. 
Este libro forma parte del acervo de la Biblioteca Jurídica Virtual del Instituto de Investigaciones Jurídicas de la UNAM

propone medidas para la mejor conversión de los mismos al cristianismo a través de métodos suaves y pacíficos:

Y esto que sea por tales modos, medios y arte y por tales leyes y ordenanzas, que se adaten a la calidad y manera y condición de la tierra y de los naturales della, de manera que ellos las puedan saber, entender y usar, y guardar y ser capaces dellas; y de esta manera son desde mi parecer, sin los entrincamientos y oscuridad y multitud de las nuestras, que no las sabrán ni entenderán ni serán capaces dellas de aquí al fin del mundo, ni se las adatarán cuantos son nacidos. ${ }^{36}$

En su análisis de la esclavitud utiliza ampliamente el derecho civil romanista para señalar que entre los indígenas no existía esclavitud como la europea, en el que vuelve hacer comentarios del papel que le asigna a las leyes provenientes del Corpus Iuris Civilis en Castilla, considerándolas únicamente como sabias razones: "...Y como lo eran cerca de los ciudadanos romanos, cuyas leyes en esto nosotros tenemos, aunque no como leyes, sino como razones de sabios...".37

Después de desempeñar el cargo de oidor en la Audiencia, Vasco de Quiroga se incorpora de lleno a su obra espiritual al aceptar el cargo de obispo de Michoacán, previa ordenación de presbítero ocurrida, probablemente, a mediados de 1536, en la que no abandonó en su actuación su clara formación jurídica, misma que se expresa en lo que Carrillo ha llamado su pastoral jurídico-canónica. Al frente de su misión pastoral, Quiroga representa un proyecto de iglesia enfrentado con la iglesia misionera, situación que Carrillo sintetiza así: "por un lado una iglesia misionera extensamente dedicada a la república de los indios, y por otro una iglesia jerárquica al estilo medieval hispánico que trataba de aplicar la misma organización parroquial de tradición

\footnotetext{
36 Ibidem, p. 113.

37 Ibidem, p. 140.
} 
Este libro forma parte del acervo de la Biblioteca Jurídica Virtual del Instituto de Investigaciones Jurídicas de la UNAM

canónica medieval hispánica a las dos repúblicas, la de españoles y la de indios". ${ }^{38}$

En esta actividad se desarrolla ampliamente el canonista Vasco de Quiroga, donde recordará todas sus lecciones de Graciano, profesor de Derecho canónico en Bolonia que elaboró una Concordantia Discordantium Canonum, es decir, armonizó las normas canónicas que parecían contradecirse, dando por resultado el famoso Decretum Gratiani alrededor de 1140, obra que siguió la sistemática del Digesto de Justiniano (obra privada que pronto se convirtió en una colección oficial). Igualmente, Vasco de Quiroga tuvo oportunidad de aplicar sus conocimientos adquiridos en el estudio de las Clementinae, normas canónicas que hizo compilar Clemente V y que luego fueron reelaboradas por Juan XXII, mismas que se hicieron prácticamente obligatorias, primeramente, en las universidades de Bolonia y París, y más tarde - como ya lo dejamos asentado - en todas las universidades europeas. Estos textos tuvieron tanto éxito que junto con otras colecciones integraron en 1500 el Corpus Iuris Canonici. ${ }^{39}$

Berman considera que el derecho canónico es nada menos que el primer sistema jurídico occidental y una gran aportación en el campo de la ciencia jurídica. ${ }^{40}$ Por su parte, Le Goff, siguiendo a Gabriel Le Bras, le llamó al derecho canónico como la mayor invención jurídica medieval, derecho que reguló el funcionamiento de la Iglesia y las relaciones de ésta con la sociedad, destacando la importancia de este ordenamiento en un mundo donde la Iglesia está omnipresente y existe una profunda impregnación jurídica de las mentalidades. ${ }^{41}$

Quiroga insistió bastante en la organización de la población indígena como una solución, y a través de ella impulsar su evangelización y conversión al cristianismo; en ello están presentes tanto sus lecturas teológicas como la obra de Tomás Moro, la

\footnotetext{
38 Carrillo Cazares, Alberto, op. cit., pp. 63 y 64.

39 Berman, Harold J., op. cit., pp. 211-215.

40 Idem.

41 Le Goff, Jacques, op. cit., pp. 114-117.
} 
Este libro forma parte del acervo de la Biblioteca Jurídica Virtual del Instituto de Investigaciones Jurídicas de la UNAM

Utopía. Con base en esta reubicación, Quiroga intentaba poner orden tanto en lo espiritual como en lo temporal, y proponía un conjunto de normas propias y específicas para los pueblos indios, muy diferente del conjunto de leyes complicado que él conocía.

Este sistema lo logró desarrollar en su proyecto de puebloshospital de Santa Fe, para los cuales emite las ordenanzas y reglas respectivas, mismas que poco o nada tienen que ver con el derecho romano o canónico que tanto sostiene en su quehacer en distintas facetas, que le llevan a señalar en la parte de justicia que los pleitos que surgieran entre ellos se resuelvan sin menester de acudir ante un juez:

Cómo se averigüen las quejas y pleitos, que nacieren entre ellos (que sean pocos o ningunos), sin menester juez...

Item si alguno de los Indios pobres de este Hospital tuviere quejas de otro, o de otros, entre vosotros mismos, con el Rector, y Regidores lo averiguareis llana y amigablemente y todos digan verdad, y nadie la niegue, porque no haya necesidad de se ir a quejar al Juez a otra parte, donde paguéis derechos, y después os echen en la cárcel. Y esto hagáis aunque uno sea perdidoso; que vale más así con paz, y concordia perder, que ganar pleiteando, y aborreciendo al prójimo, y procurando vencerle, y dañarle, pues habéis de ser en este Hospital todos hermanos en Jesucristo con vinculo de paz, y caridad, como se os encarga, y encomienda mucho. ${ }^{42}$

Aquí aparece la otra cultura medieval de Quiroga: su confianza en la costumbre y el reconocimiento de los derechos propios como característica del derecho medieval. Como señala Le Goff:

De forma espontánea, quien habla de Derecho piensa de inmediato en el derecho romano, en la herencia imperial, tan fuerte en Occidente. Se subestima así la importancia y la creatividad del Derecho en la civilización medieval. Sin duda, porque el derecho romano se impone como un derecho escrito, mientras que el derecho medieval se basa en costumbres y tradiciones orales. ${ }^{43}$

\footnotetext{
42 Quiroga, Vasco de, op. cit., p. 269.

43 Le Goff, Jacques, op. cit., p. 114.
} 
Este libro forma parte del acervo de la Biblioteca Jurídica Virtual del Instituto de Investigaciones Jurídicas de la UNAM

El derecho en la época medieval es una experiencia y una mentalidad que expresa más bien las reglas ordenadoras de la vida cotidiana, y porque el derecho deja en esa época "a los particulares que se auto organicen libremente, estas estructuras son las que están menos condicionadas por injerencias de la autoridad y nos transmiten el mensaje más genuino de las fuerzas - espirituales, culturales, sociales - efectivamente circulantes en la sociedad". ${ }^{44}$ Esta circunstancia no desaparece en los momentos de madurez del derecho y la sociedad medieval (siglos XII-XIV) cuando se forma el ius commune, época en la que, en buena medida, emergen derechos particulares por la ausencia del Estado.

Esta circunstancia la advirtió de alguna manera el jurista moreliano Felipe Tena Ramírez, al estudiar las ordenanzas de Quiroga y comparar sus tesis con las contenidas en el libro de Tomás Moro, y subrayar la autonomía de los pueblos-hospital de Santa Fe:

Después de haber señalado en el capítulo anterior las coincidencias y sus matices entre el libro de Moro y las Ordenanzas de Quiroga, procederemos ahora a marcar, entre la obra abstracta del primero y su realización concreta llevada a cabo por el segundo, una diferencia capital, suficiente por sí sola para situarla fuera del perímetro ideológico de la creación imaginaria de Tomás Moro. Nos referimos a la autonomía que al margen de toda forma de estatismo presidió siempre el destino de los pueblos-hospitales, frente al rígido sistema autoritario instituido en la ínsula de Utopía. Es allí donde Don Vasco se emancipa del modelo, al liberar a sus comunidades asistenciales de toda intervención coactiva del poder público... En el régimen de Quiroga la protección de la norma competía a una ordenación familiar, que actuaba mediante la persuasión y no por la imposición. ${ }^{45}$

Nos encontramos así en una disyuntiva falsa de si ubicar a Quiroga como un medievalista o un renacentista; tal parece que

44 Grossi, Paolo, op. cit., p. 114.

45 Tena Ramírez, Felipe, Vasco de Quiroga y sus pueblos de Santa Fe en los siglos XVIII y XIX, México, Porrúa, 1977, pp. 98 y 97. 
Este libro forma parte del acervo de la Biblioteca Jurídica Virtual del Instituto de Investigaciones Jurídicas de la UNAM

ubicarlo en uno u otro lado derivaría en su carácter revolucionario o no. En buena medida, esta disyuntiva deriva de la errónea concepción que tenemos de la Edad Media; de acuerdo con Le Goff, la Edad Media fue dinámica e intensamente creadora, aunque no se reconozca por sus propios intelectuales:

....al contrario en la Iglesia - y entonces la Iglesia abarcaba toda la vida intelectual - la palabra novitas novedad, llena de temor y hostilidad a quien la escucha. Decir de un autor que es nuevo supone condenarlo: igual que tacharle de herejía maligna. Los creadores, numerosos en la Edad Media, rechazan esta sospecha. Afirman ser los imitadores de autoridades venerables. Según dicen retoman ideas antiguas, les quitan el polvo y las hacen renacer. ${ }^{46}$

Vasco de Quiroga como funcionario real cree en las leyes del reino; reconoce a las romanas como opiniones de sabios venerables; acepta su misión evangélica apoyado en los cánones de la Iglesia y su derecho compilado; crea pueblos bajo un modelo novedoso y con un derecho basado en la costumbre que viene desde abajo; sin embargo, no es un autor que pretende ser nuevo - parafraseando a Le Goff-, lo que busca es renacer. Por ello, me parece que puede aplicarse en él, el concepto de renacentista medieval.

\section{BIBLIOGRAFÍA}

BARRIENTOS GRANDON, Javier, La cultura jurídica en la Nueva España, México, UNAM, 1993.

BERMAN, Harold J., La formación de la tradición jurídica de Occidente, México, Fondo de Cultura Económica, 1996.

Boletín de la Escuela de Jurisprudencia, Morelia, 15 de abril de 1901. CARrillo CaZARES, Alberto, Vasco de Quiroga: la pasión por el derecho, Zamora, El Colegio de Michoacán-Arquidiócesis de MoreliaUniversidad Michoacana de San Nicolás de Hidalgo, 2003.

46 Le Goff, Jacques, op. cit., p. 52. 
Este libro forma parte del acervo de la Biblioteca Jurídica Virtual del Instituto de Investigaciones Jurídicas de la UNAM

Castañeda Delgado, Paulino, La teocracia pontifical en las controversias sobre el Nuevo Mundo, México, UNAM, Instituto de Investigaciones Jurídicas, 1996.

FERnández De BujÁn, Antonio, Derecho público romano y recepción del derecho romano en Europa, Madrid, Civitas, 1999.

García García, Antonio, "Derecho romano-canónico en la península ibérica", en ALVARADO, Javier (ed.), Historia de la literatura jurídica en la España del antiguo régimen, Madrid, Marcial Pons, 2000.

Grossi, Paolo, El orden jurídico medieval, Madrid, Marcial Pons, 1996.

Hespanha, António Manuel, Cultura jurídica europea. Síntesis de un milenio, Madrid, Tecnos, 2002.

LE Goff, Jacques, En busca de la Edad Media, Barcelona, Paidós, 2003.

MARGADANT, Guillermo, La Iglesia ante el derecho mexicano. Esbozo histórico-jurídico, México, Miguel Ángel Porrúa, 1991.

Miranda Godínez, Francisco, Don Vasco de Quiroga y su Colegio de San Nicolás, Morelia, Universidad Michoacana de San Nicolás de Hidalgo, 1990.

PÉREz MARTín, Antonio, "La literatura jurídica castellana en la Baja Edad Media", en AlvarADO, Javier (ed.), Historia de la literatura jurídica en la España del antiguo régimen, Madrid, Marcial Pons, 2000.

Quiroga, Vasco de, Información en derecho, biografia e ideario, Morelia, Universidad Michoacana de San Nicolás de Hidalgo-Gobierno del Estado de Michoacán, 1992.

SALORD BERTRÁN, Manuel Ma., La influencia de Francisco de Vitoria en el derecho indiano, México, Porrúa, 2002.

Serrano Gasset, Paz, Vasco de Quiroga. La utopía en América, Madrid, Dastin, 2003.

Tena Ramírez, Felipe, Vasco de Quirogay sus pueblos de Santa Fe en los siglos XVIII y XIX, México, Porrúa, 1977. 
Este libro forma parte del acervo de la Biblioteca Jurídica Virtual del Instituto de Investigaciones Jurídicas de la UNAM

Tomás y VALIEnTe, Francisco, "Manual de historia del derecho español", Obras completas, Madrid, Centro de Estudios Políticos y Constitucionales, 1997, vol. II.

Trueba, Alfonso, Don Vasco, México, Jus, 1958.

Zavala, Silvio, Por la senda hispana de la libertad, México, Fondo de Cultura Económica-MAPFRE, 1993.

Warren, J. B., Vasco de Quiroga y sus hospitales-pueblo de Santa Fe, Morelia, Universidad Michoacana de San Nicolás de Hidalgo, 1977. 
Vasco de Quiroga en el 450 aniversario de su muerte (15652015), editado por el Instituto de Investigaciones Jurídicas de la UNAM, se terminó de imprimir el 7 de abril de 2017 en los talleres de Arte Gráfico y Sonoro, Agys Alevin, S. C., Retorno de Amores 14-102, colonia Del Valle, delegación Benito Juárez, 03100 Ciudad de México, tel. 5523 1151. Se utilizó tipo Baskerville de 9, 10 y 11 puntos. En esta edición se empleó papel cultural 57 x 87 de 75 gramos para los interiores y cartulina couché de 250 gramos para los forros.

Consta de 200 ejemplares (impresión digital). 
a Universidad Nacional Autónoma de México, a través de la Coordinación de Humanidades, el Instituto de Investigaciones Jurídicas y la Unidad Académica de Estudios Regionales en Jiquilpan de Juárez, Michoacán, en unión con El Colegio de Michoacán, la Universidad Michoacana de San Nicolás de Hidalgo y la Universidad de La Ciénega del Estado de Michoacán de Ocampo, trabajan en un seminario permanente sobre el desarrollo constitucional en México.

Se han llevado a cabo diversas actividades académicas, como seminarios, congresos internacionales y coloquios, a saber: septiembre de 2011, seminario "Independencia y Constitución"; septiembre de 2012, congreso internacional "La Constitución de Cádiz a doscientos años; perspectiva e impacto en el occidente novohispano", y octubre de 2014, congreso internacional "A doscientos años de la Constitución de Apatzingán".

En 2015 se llevó a cabo el coloquio "Vasco de Quiroga en el 450 aniversario de su muerte, 1565-2015", en el auditorio "Francisco J. Múgica" de la Unidad Académica de Estudios Regionales de la Coordinación de Humanidades de la UNAM. En el presente volumen se incorporan las ponencias presentadas al mismo.

\section{.}

